National Water-Quality Assessment Program

\title{
Vertical Gradients in Water Chemistry and Age in the Northern High Plains Aquifer, Nebraska, 2003
}

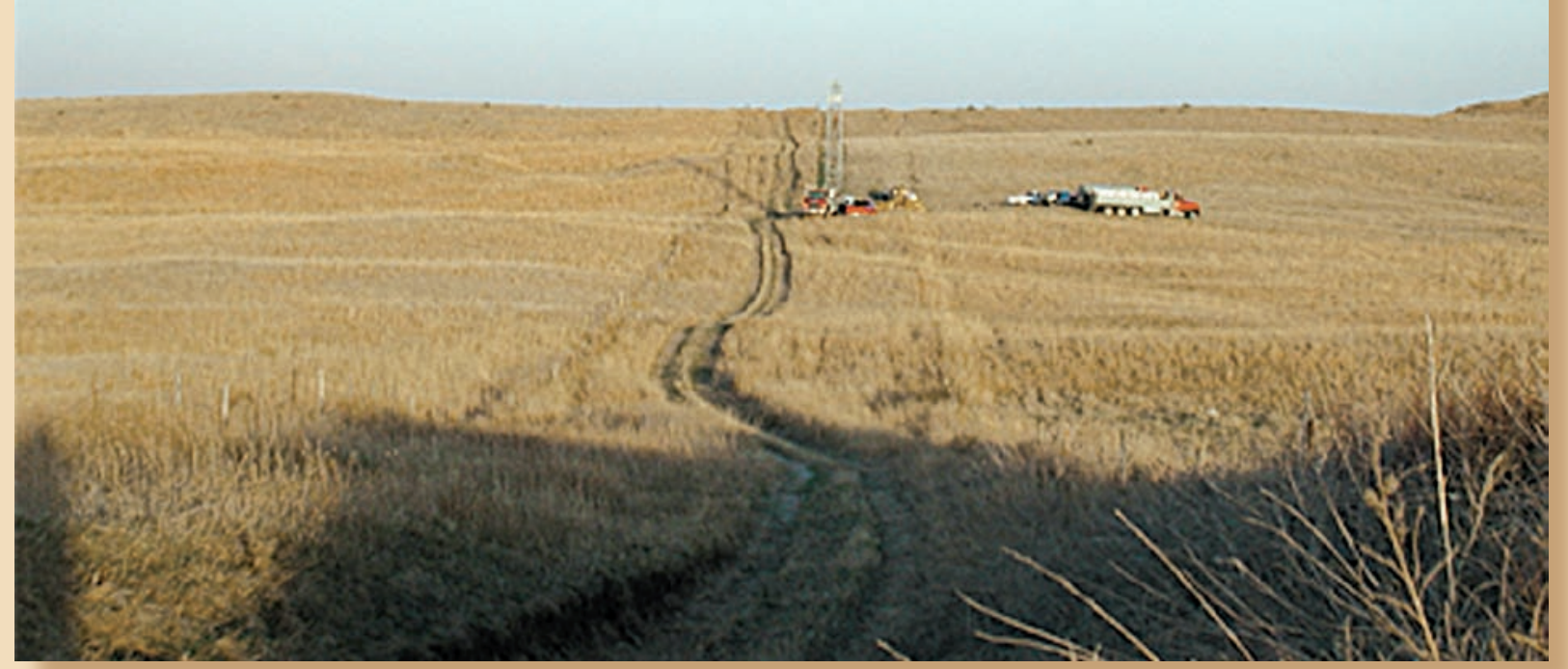

Scientific Investigations Report 2006-5294 


\section{Vertical Gradients in Water Chemistry and Age in the Northern High Plains Aquifer, Nebraska, 2003}

By P.B. McMahon, ${ }^{1}$ J.K. Böhlke, ${ }^{1}$ and C.P. Carney ${ }^{2}$

'U.S. Geological Survey

${ }^{2}$ Nebraska Public Power District

National Water-Quality Assessment Program

Scientific Investigations Reports 2006-5294 


\section{U.S. Department of the Interior DIRK KEMPTHORNE, Secretary}

\section{U.S. Geological Survey \\ Mark D. Myers, Director}

\section{U.S. Geological Survey, Reston, Virginia: 2007}

For product and ordering information:

World Wide Web: http://www.usgs.gov/pubprod

Telephone: 1-888-ASK-USGS

For more information on the USGS--the Federal source for science about the Earth, its natural and living resources, natural hazards, and the environment:

World Wide Web: http://www.usgs.gov

Telephone: 1-888-ASK-USGS

Any use of trade, product, or firm names is for descriptive purposes only and does not imply endorsement by the U.S. Government.

Although this report is in the public domain, permission must be secured from the individual copyright owners to reproduce any copyrighted materials contained within this report.

Suggested citation:

McMahon, P.B., Böhlke, J.K., and Carney, C.P., 2007, Vertical gradients in water chemistry and age in the northern High Plains aquifer, Nebraska, 2003: U.S. Geological Survey Scientific Investigations Report 2006-5294, 58 p. 


\section{Contents}

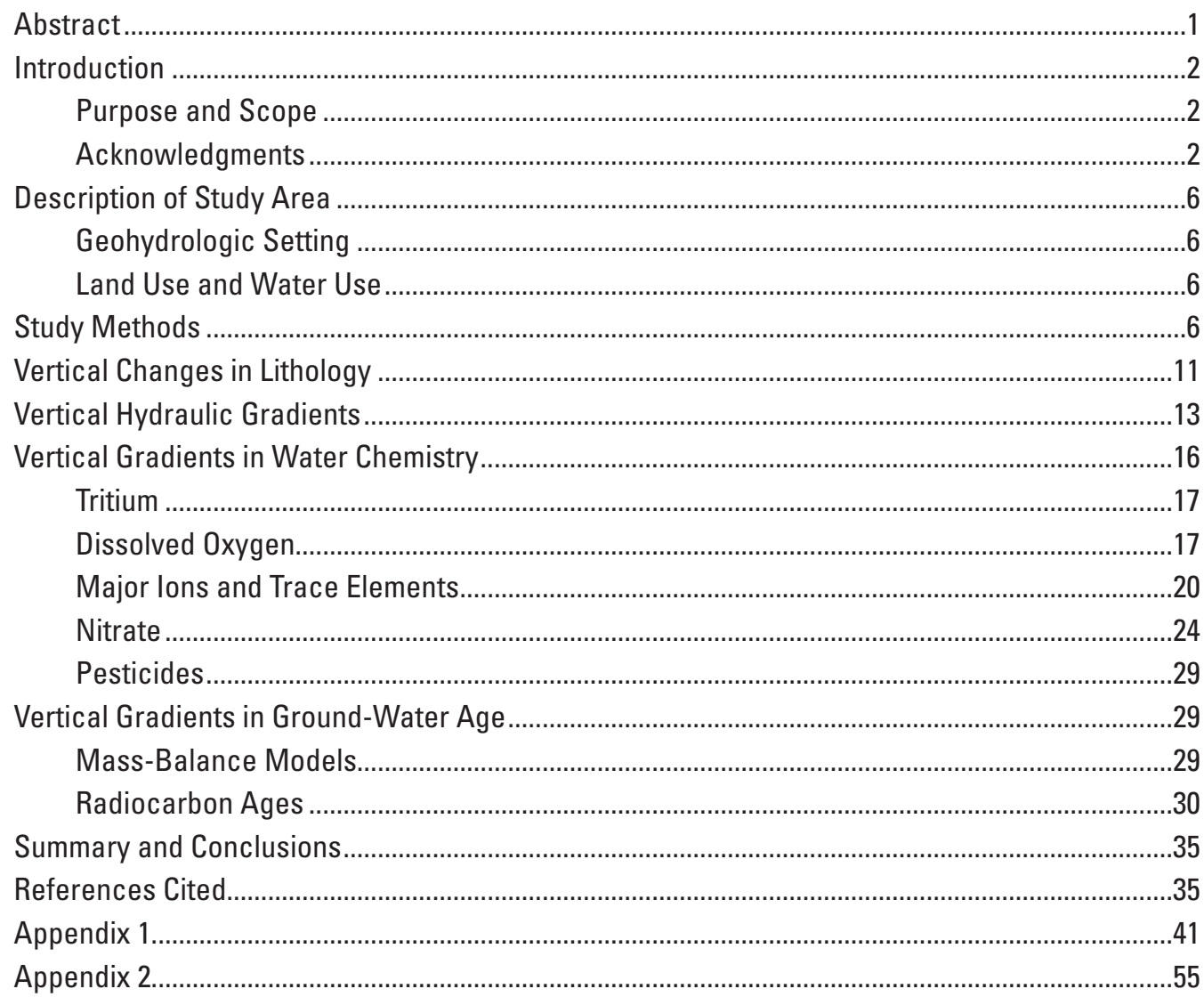

\section{Figures}

\section{1-5. Maps showing:}

1. Land-surface elevations and locations of the northern, central, and southern parts of the High Plains aquifer ..............................................................

2. Ground-water elevations in the northern High Plains aquifer and locations of the ground-water and surface-water sampling sites.................................4

3. Saturated thickness of the northern High Plains aquifer and locations of the ground-water and surface-water sampling sites ...........................................

4. Location of registered irrigation wells in the northern High Plains and locations of the ground-water and surface-water sampling sites.........................8

5. Land use overlying the northern High Plains aquifer and locations of the ground-water and surface-water sampling sites

6. Geohydrologic section between nested-well sites showing locations of the monitoring-well screens

7. Natural gamma and resistivity logs for boreholes at the nested-well sites....................12

8. Water-level elevations and vertical hydraulic gradients at the nested wells..................16 
9. Concentrations of selected dissolved constituents in relation to well-screen depth below the water table.

10. Concentrations of selected dissolved constituents and mineral saturation indexes in relation to concentrations of dissolved inorganic carbon in water from the nested wells

11. Strontium isotope ratios in relation to inverse strontium concentrations for water from the water-table and nested wells.

12. Sulfur isotope ratios in relation to inverse sulfate concentrations for water from the water-table and nested wells.

13. Concentrations of dissolved bromide in relation to concentrations of dissolved chloride in water from the nested wells and in precipitation

14. (A) Oxygen isotope values for nitrate in relation to nitrogen isotope values for nitrate and (B) fraction of initial nitrate in recharge remaining in solution in relation to well-screen depth below the water table for water from the nested wells

15. Adjusted radiocarbon age in relation to depth below the water table

16. Schematic diagram illustrating a method for calculating the maximum percentage of saturated thickness containing recently recharged water

17. Measured and modeled age distributions used to estimate long-term average recharge rates

\section{Tables}

1. Construction information for monitoring wells

2. Lithologic description and mineralogy of selected drill cuttings ...

3. Carbon content of sediments and $\delta^{13} \mathrm{C}$ and $\delta^{18} 0$ compositions of bulk carbonate..........15

4. Isotopic data from sampled monitoring wells screened in the northern High Plains aquifer and from the Platte River near Brady, Nebraska.

5. Dissolved-gas and related data, recharge temperatures, and estimates of initial nitrate concentration and isotope values in recharge.

6. Summary of ground-water ages from tritium and radiocarbon dating ............................31

7. Apparent rates of dissolved-oxygen reduction and denitrification. 


\section{Conversion Factors, Vertical datum, and abbreviations}

\begin{tabular}{lll}
\hline Multiply & By & To obtain \\
\hline inch (in.) & Length & \\
foot (ft) & 2.54 & centimeter $(\mathrm{cm})$ \\
mile (mi) & 0.3048 & meter $(\mathrm{m})$ \\
\hline & 1.609 & kilometer $(\mathrm{km})$ \\
\hline acre & Area & hectare $(\mathrm{ha})$ \\
square miles $\left(\mathrm{mi}^{2}\right)$ & 0.4047 & Square kilometers $\left(\mathrm{km}^{2}\right)$ \\
\hline & 2.59 & liter $(\mathrm{L})$ \\
\hline gallon $(\mathrm{gal})$ & Volume & cubic meter $\left(\mathrm{m}^{3}\right)$ \\
\hline acre-foot $(\mathrm{acre}-\mathrm{ft})$ & 3.785 & \\
\hline gallon per minute $(\mathrm{gal} / \mathrm{min})$ & 1,233 & liter per second $(\mathrm{L} / \mathrm{s})$ \\
\hline & Flow rate \\
\hline picocurie per liter $(\mathrm{pCi} / \mathrm{L})$ & 0.06309 & \\
\hline
\end{tabular}

Temperature in degrees Celsius $\left({ }^{\circ} \mathrm{C}\right)$ may be converted to degrees Fahrenheit $\left({ }^{\circ} \mathrm{F}\right)$ as follows:

$$
{ }^{\circ} \mathrm{F}=\left(1.8 \times^{\circ} \mathrm{C}\right)+32
$$

Temperature in degrees Fahrenheit $\left({ }^{\circ} \mathrm{F}\right)$ may be converted to degrees Celsius $\left({ }^{\circ} \mathrm{C}\right)$ as follows:

$$
{ }^{\circ} \mathrm{C}=\left({ }^{\circ} \mathrm{F}-32\right) / 1.8
$$

Vertical coordinate information is referenced to the National Geodetic Vertical Datum of 1929 (NGVD 29).

Horizontal coordinate information is referenced to the North American Datum of 1983 (NAD 83). 


\section{Foreword}

The U.S. Geological Survey (USGS) is committed to providing the Nation with credible scientific information that helps to enhance and protect the overall quality of life and that facilitates effective management of water, biological, energy, and mineral resources (http://www.usgs. gov/). Information on the Nation's water resources is critical to ensuring long-term availability of water that is safe for drinking and recreation and is suitable for industry, irrigation, and fish and wildlife. Population growth and increasing demands for water make the availability of that water, now measured in terms of quantity and quality, even more essential to the long-term sustainability of our communities and ecosystems.

The USGS implemented the National Water-Quality Assessment (NAWQA) Program in 1991 to support national, regional, State, and local information needs and decisions related to water-quality management and policy (http://water.usgs.gov/nawqa). The NAWQA Program is designed to answer: What is the condition of our Nation's streams and ground water? How are conditions changing over time? How do natural features and human activities affect the quality of streams and ground water, and where are those effects most pronounced? By combining information on water chemistry, physical characteristics, stream habitat, and aquatic life, the NAWQA Program aims to provide science-based insights for current and emerging water issues and priorities. From 1991-2001, the NAWQA Program completed interdisciplinary assessments and established a baseline understanding of water-quality conditions in 51 of the Nation's river basins and aquifers, referred to as Study Units (http://water.usgs.gov/nawqa/studyu.html).

In the second decade of the Program (2001-2012), a major focus is on regional assessments of water-quality conditions and trends. These regional assessments are based on major river basins and principal aquifers, which encompass larger regions of the country than the Study Units. Regional assessments extend the findings in the Study Units by filling critical gaps in characterizing the quality of surface water and ground water, and by determining status and trends at sites that have been consistently monitored for more than a decade. In addition, the regional assessments continue to build an understanding of how natural features and human activities affect water quality. Many of the regional assessments employ modeling and other scientific tools, developed on the basis of data collected at individual sites, to help extend knowledge of water quality to unmonitored, yet comparable areas within the regions. The models thereby enhance the value of our existing data and our understanding of the hydrologic system. In addition, the models are useful in evaluating various resource-management scenarios and in predicting how our actions, such as reducing or managing nonpoint and point sources of contamination, land conversion, and altering flow and (or) pumping regimes, are likely to affect water conditions within a region.

Other activities planned during the second decade include continuing national syntheses of information on pesticides, volatile organic compounds (VOCs), nutrients, selected trace elements, and aquatic ecology; and continuing national topical studies on the fate of agricultural chemicals, effects of urbanization on stream ecosystems, bioaccumulation of mercury in stream ecosystems, effects of nutrient enrichment on stream ecosystems, and transport of contaminants to public-supply wells.

The USGS aims to disseminate credible, timely, and relevant science information to address practical and effective water-resource management and strategies that protect and restore water quality. We hope this NAWQA publication will provide you with insights and information to meet your needs, and will foster increased citizen awareness and involvement in the protection and restoration of our Nation's waters. 
The USGS recognizes that a national assessment by a single program cannot address all waterresource issues of interest. External coordination at all levels is critical for cost-effective management, regulation, and conservation of our Nation's water resources. The NAWQA Program, therefore, depends on advice and information from other agencies-Federal, State, regional, interstate, Tribal, and local—as well as nongovernmental organizations, industry, academia, and other stakeholder groups. Your assistance and suggestions are greatly appreciated.

Robert M. Hirsch

Associate Director for Water 


\title{
Vertical Gradients in Water Chemistry and Age in the Northern High Plains Aquifer, Nebraska, 2003
}

\author{
By P.B. McMahon, J.K. Böhlke, and C.P. Carney
}

\section{Abstract}

The northern High Plains aquifer is the primary source of water used for domestic, industrial, and irrigation purposes in parts of Colorado, Kansas, Nebraska, South Dakota, and Wyoming. Despite the aquifer's importance to the regional economy, fundamental ground-water characteristics, such as vertical gradients in water chemistry and age, remain poorly defined. As part of the U.S. Geological Survey's National Water-Quality Assessment Program, water samples from nested, short-screen monitoring wells installed in the northern High Plains aquifer were analyzed for major ions, nutrients, trace elements, dissolved organic carbon, pesticides, stable and radioactive isotopes, dissolved gases, and other parameters to evaluate vertical gradients in water chemistry and age in the aquifer. Chemical data and tritium and radiocarbon ages show that water in the aquifer was chemically and temporally stratified in the study area, with a relatively thin zone of recently recharged water (less than 50 years) near the water table overlying a thicker zone of older water $(1,800$ to 15,600 radiocarbon years). In areas where irrigated agriculture was an important land use, the recently recharged ground water was characterized by elevated concentrations of major ions and nitrate and the detection of pesticide compounds. Below the zone of agricultural influence, major-ion concentrations exhibited small increases with depth and distance along flow paths because of rock/water interactions. The concentration increases were accounted for primarily by dissolved calcium, sodium, bicarbonate, sulfate, and silica. In general, the chemistry of ground water throughout the aquifer was of high quality. None of the approximately 90 chemical constituents analyzed in each sample exceeded primary drinking-water standards.

Mass-balance models indicate that changes in groundwater chemistry along flow paths in the aquifer can be accounted for by small amounts of feldspar and calcite dissolution; goethite and clay-mineral precipitation; organic-carbon and pyrite oxidation; oxygen reduction and denitrification; and cation exchange. Mixing with surface water affected the chemistry of ground water in alluvial sediments of the Platte River Valley. Radiocarbon ages in the aquifer, adjusted for carbon mass transfers, ranged from 1,800 to $15,600{ }^{14} \mathrm{C}$ years before present. These results have important implications with respect to development of ground-water resources in the Sand Hills.
Most of the water in the aquifer predates modern anthropogenic activity so excessive removal of water by pumping is not likely to be replenished by natural recharge in a meaningful timeframe. Vertical gradients in ground-water age were used to estimate long-term average recharge rates in the aquifer. In most areas, the recharge rates ranged from 0.02 to 0.05 foot per year. The recharge rate was 0.2 foot per year in one part of the aquifer characterized by large downward hydraulic gradients.

Nitrite plus nitrate concentrations at the water table were 0.13 to 3.13 milligrams per liter as nitrogen, and concentrations substantially decreased with depth in the aquifer. Dissolved-gas and nitrogen-isotope data indicate that denitrification in the aquifer removed 0 to 97 percent (average $=$ 50 percent) of the nitrate originally present in recharge. The average amount of nitrate removed by denitrification in the aquifer north of the Platte River (Sand Hills) was substantially greater than the amount removed south of the river (66 as opposed to 0 percent), and the extent of nitrate removal appears to be related to the presence of thick deposits of sediment on top of the Ogallala Group in the Sand Hills that contained electron donors, such as organic carbon and pyrite, to support denitrification.

Apparent rates of dissolved-oxygen reduction and denitrification were estimated on the basis of decreases in dissolved-oxygen concentrations and increases in concentrations of excess nitrogen gas and ground-water ages along flow paths from the water table to deeper wells. Median rates of dissolved-oxygen reduction and denitrification south of the Platte River were at least 10 times smaller than the median rates north of the river in the Sand Hills. The relatively large denitrification rates in the Sand Hills indicate that the aquifer in that area may have a greater capacity to attenuate nitrate contamination than the aquifer south of the river, depending on rates of ground-water movement in the two areas. Small denitrification rates south of the river indicate that nitrate contamination in that part of the aquifer would likely persist for a longer period of time. 


\section{Introduction}

In 1991, the U.S. Geological Survey (USGS) began full implementation of the National Water-Quality Assessment (NAWQA) Program. The long-term goals of the NAWQA Program are to describe the status and trends in the quality of the Nation's surface- and ground-water resources and determine the natural and anthropogenic factors affecting water quality (Gilliom and others, 1995). The High Plains Regional GroundWater study, which began in June 1998, is one of more than 50 major river basins and aquifers being studied by the NAWQA Program. The High Plains aquifer is a nationally important water resource that underlies about $174,000 \mathrm{mi}^{2}$ in parts of eight States (fig. 1). In 2000, about 30 percent of the ground water used for irrigation in the United States was pumped from this aquifer (Maupin and Barber, 2005). About 2 percent of the water pumped from the aquifer was used for drinking (Maupin and Barber, 2005). Because of the large areal extent of the High Plains aquifer, three geographic regions have been delineated for logistical purposes: northern High Plains $\left(96,500 \mathrm{mi}^{2}\right)$, central High Plains $\left(48,500 \mathrm{mi}^{2}\right)$, and southern High Plains $\left(29,000 \mathrm{mi}^{2}\right)$ (fig. 1). The northern High Plains aquifer is the focus of this report. Reports similar to this one already have been published for the central and southern High Plains aquifers (McMahon, 2001; McMahon and others, 2004a, b).

The northern High Plains aquifer is one of the primary sources of water used for domestic, industrial, and irrigation purposes in Nebraska, and in parts of Colorado, Kansas, South Dakota, and Wyoming. In addition, it contains the largest amount of ground water in storage and the largest saturated thicknesses of the entire High Plains aquifer system (McGuire and Sharpe, 1997). Despite the aquifer's importance to the overall economy of the northern High Plains and the size of this resource, fundamental ground-water characteristics, such as vertical gradients in water chemistry and age, remain poorly defined. Understanding how water chemistry changes with depth in the aquifer is relevant because current or future waterlevel declines could increase the demand for water deeper in the aquifer. Contamination of shallow parts of the aquifer by sources at the land surface also could increase the demand for water deeper in the aquifer. Ground-water age distributions in aquifers are relevant because, when combined with other hydrogeologic and geochemical information, they can provide insights into recharge rates, an aquifer's susceptibility to contamination from sources at the land surface, and biogeochemical reaction rates.

Numerous studies have examined water quality in the northern High Plains aquifer at various spatial scales, including those by Engberg and Spalding (1978), Krothe and others (1982), Engberg (1984), Johnson and others (1986), Exner and Spalding (1990), Verstraeten and others (1995), Druliner and others (1996), Gottula (1996), Gosselin and others (1997a), Litke (2001), and Stanton (2006). Those studies relied primarily on water samples collected from domestic and irrigation wells, which often have relatively long screened intervals that are not well suited for describing vertical gradients in water chemistry and age. Some studies have used water samples collected from short-screen monitoring wells to examine vertical gradients in water chemistry in the aquifer (Spalding and others, 1993; Steele and others, 1998; Emmons and Bowman, 2000) and age in the aquifer (Druliner, 1997; Spalding and others, 2001; Verstraeten and others, 2001). Most of those studies focused on shallow zones in the aquifer or on parts of the aquifer that have relatively thin saturated thicknesses and short ground-water residence times. Even in those settings, however, gradients in ground-water chemistry and age were evident. Information like this is needed in parts of the aquifer where saturated thicknesses are large and development of the deep ground-water resource has not occurred so that baseline conditions in those areas can be established.

\section{Purpose and Scope}

The purpose of this report is to provide baseline information on vertical gradients in water chemistry and age in selected areas of the northern High Plains aquifer in Nebraska where saturated thicknesses are large but extensive development of the deep ground-water resource has not occurred. In 2002 and 2003, 19 monitoring wells at 5 sites were completed in the aquifer (fig. 2 and table 1). The wells had 10-ft-long screens that were placed at various depths below the water table. In 2003 and 2004, water samples were collected from each well and from the Platte River and were analyzed for major ions; nutrients; trace elements; dissolved organic carbon (DOC); pesticides; dissolved helium (He), methane $\left(\mathrm{CH}_{4}\right)$, neon $(\mathrm{Ne})$, nitrogen $\left(\mathrm{N}_{2}\right)$, oxygen $\left(\mathrm{O}_{2}\right)$, and argon ( $\left.\mathrm{Ar}\right)$ gases; tritium $\left({ }^{3} \mathrm{H}\right)$; stable isotopes of water $\left(\delta^{2} \mathrm{H}\left[\mathrm{H}_{2} \mathrm{O}\right]\right.$ and $\left.\delta^{18} \mathrm{O}\left[\mathrm{H}_{2} \mathrm{O}\right]\right)$; stable isotopes of dissolved nitrate $\left(\delta^{15} \mathrm{~N}\left[\mathrm{NO}_{3}\right]\right.$ and $\left.\delta^{18} \mathrm{O}\left[\mathrm{NO}_{3}\right]\right)$ and nitrogen isotope of $\mathrm{N}_{2}$ gas $\left(\delta^{15} \mathrm{~N}\left[\mathrm{~N}_{2}\right]\right)$; stable and radioactive isotopes of dissolved inorganic carbon $\left(\delta^{13} \mathrm{C}[\mathrm{DIC}]\right.$ and $\left.{ }^{14} \mathrm{C}[\mathrm{DIC}]\right)$; stable isotopes of dissolved sulfate $\left(\delta^{34} \mathrm{~S}\left[\mathrm{SO}_{4}\right]\right)$; and the dissolved strontium isotope ratio ${ }^{87} \mathrm{Sr} /{ }^{86} \mathrm{Sr}$. Alkalinity, $\mathrm{pH}$, temperature, specific conductance, $\mathrm{O}_{2}$, and turbidity of the water were measured in the field prior to sample collection. Existing data from two additional wells, Imperial and Keith County (Co.) \#1 (table 1), also were used in the analysis.

\section{Acknowledgments}

The cooperation of landowners who agreed to the installation of monitoring wells on their property is gratefully acknowledged. Borehole drilling and well installations were done in collaboration with the Platte River Cooperative Hydrology Study (COHYST). We thank Jim Goeke, Nebraska Conservation and Survey Division, for his contributions during the drilling phase of this project. We thank Glen Bowers, Twin Platte Natural Resources District, for help in procuring landowner permissions for well installations. X-ray diffrac- 


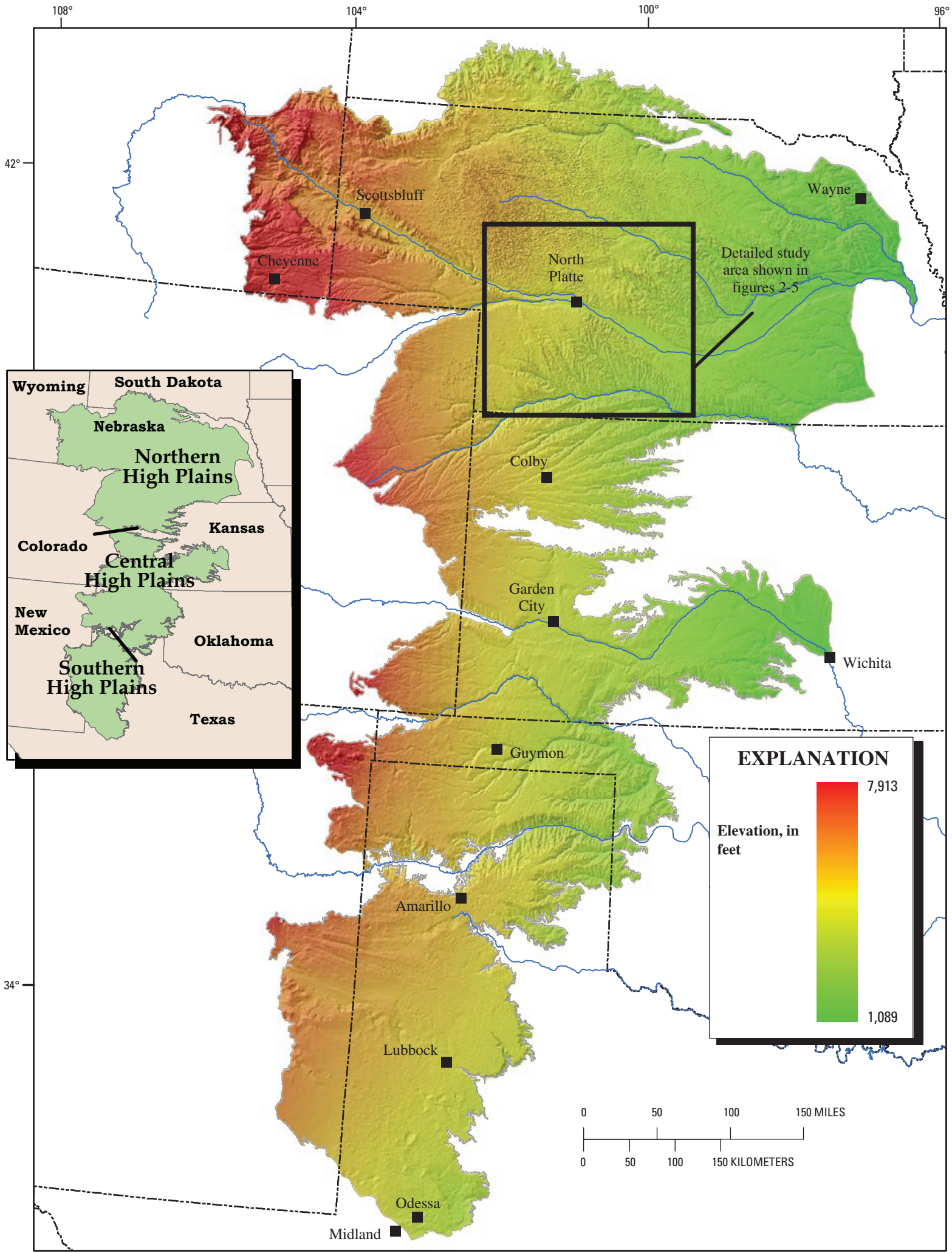

Base information from U.S. Geological Survey digital data, 1:100,000 Albers Equal-Area projectio

Standard Parallels $29^{\circ} 30^{\prime}$ and $45^{\circ} 30^{\prime}$, central meridian $-96^{\circ}$

Figure 1. Land-surface elevations and locations of the northern, central, and southern parts of the High Plains aquifer. 


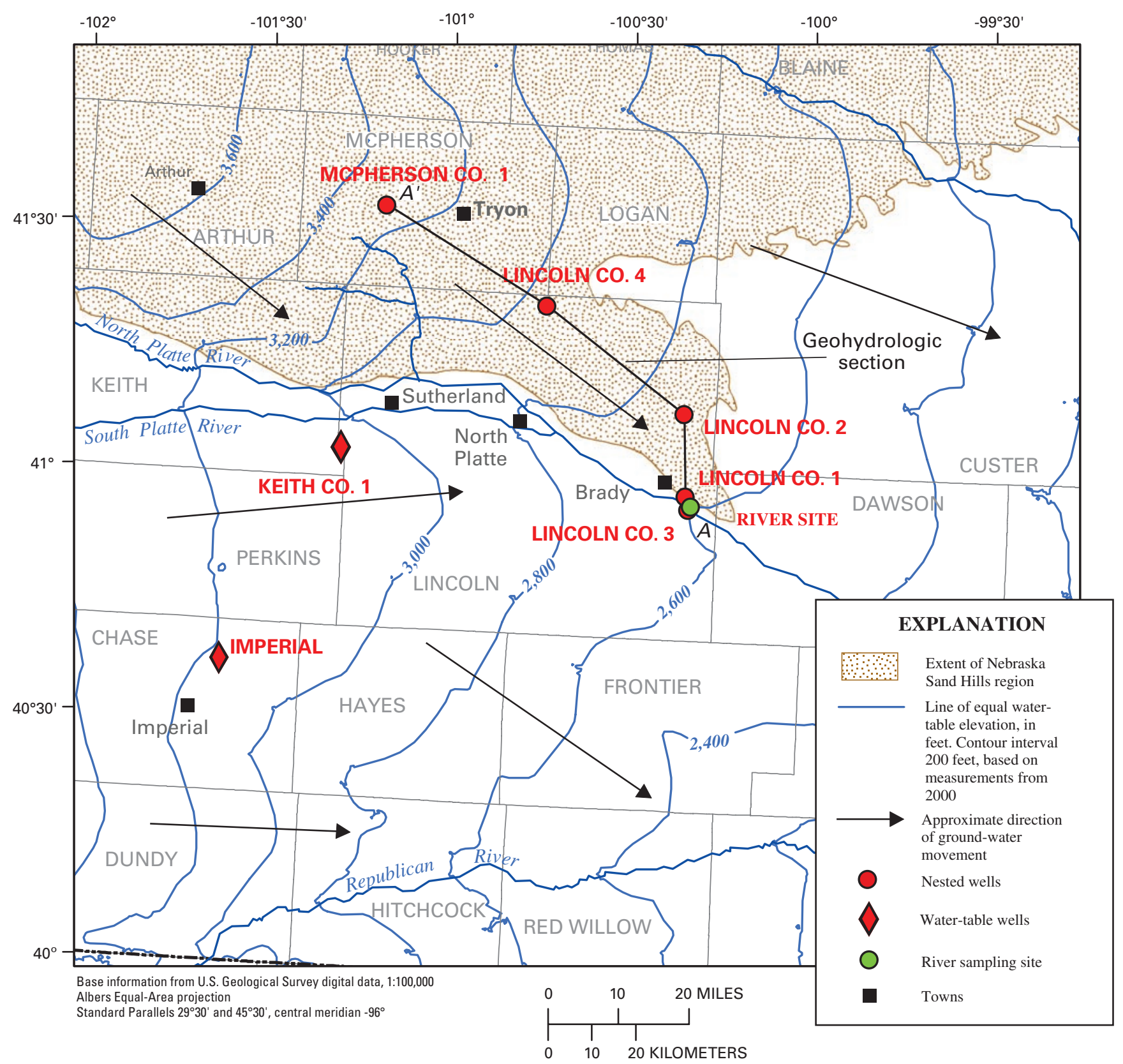

Figure 2. Ground-water elevations in the northern High Plains aquifer and locations of the ground-water and surface-water sampling sites. Elevations based on 2000 water-level measurements (V.L. McGuire, U.S. Geological Survey, written commun., 2006). 
Table 1. Construction information for monitoring wells.

[All depths are in feet below land surface; casing and screen for all wells are made of threaded, flush-joint, Schedule 40 or Schedule 80 polyvinyl chloride (PVC) with a diameter of 2.0 or 2.5 inches; screen openings are 0.020 inch wide; --, not measured.]

\begin{tabular}{|c|c|c|c|c|c|c|c|c|c|}
\hline $\begin{array}{c}\text { Site } \\
\text { identification }\end{array}$ & $\begin{array}{l}\text { Well } \\
\text { name }\end{array}$ & $\begin{array}{l}\text { Con- } \\
\text { struction } \\
\text { date }\end{array}$ & $\begin{array}{c}\text { Elevation } \\
\text { of land } \\
\text { surface } \\
\text { (feet) }\end{array}$ & $\begin{array}{c}\text { Depth to } \\
\text { base of } \\
\text { aquifer } \\
\text { (feet) }\end{array}$ & $\begin{array}{c}\text { Depth to } \\
\text { water at } \\
\text { time of } \\
\text { sampling } \\
\text { (feet) }\end{array}$ & $\begin{array}{c}\text { Total } \\
\text { depth } \\
\text { of hole } \\
\text { (feet) }\end{array}$ & $\begin{array}{c}\text { Total } \\
\text { depth } \\
\text { of well } \\
\text { (feet) }\end{array}$ & $\begin{array}{c}\text { Depth } \\
\text { of screened } \\
\text { interval } \\
\text { (feet) }\end{array}$ & $\begin{array}{c}\text { Depth of } \\
\text { screen } \\
\text { midpoint } \\
\text { below } \\
\text { water } \\
\text { table at } \\
\text { time of } \\
\text { sampling } \\
\text { (feet) }\end{array}$ \\
\hline 403713101334401 & Imperial & $6 / 9 / 02$ & 3,294 & -- & 91.60 & 109 & 109 & 95 to 104 & 7.90 \\
\hline 410344101154201 & Keith County \#1 & $7 / 25 / 05$ & 3,275 & 448 & 148.75 & 480 & 180 & 170 to 175 & 23.75 \\
\hline 405937100183504 & $\begin{array}{l}\text { Lincoln County } \\
\quad \# 1-25\end{array}$ & $4 / 17 / 02$ & 2,633 & 380 & 12.80 & 420 & 25 & 15 to 25 & 7.20 \\
\hline 405937100183503 & $\begin{array}{l}\text { Lincoln County } \\
\quad \# 1-119\end{array}$ & $11 / 13 / 02$ & 2,633 & 380 & 13.85 & 275 & 124 & 109 to 119 & 100.15 \\
\hline 405937100183502 & $\begin{array}{l}\text { Lincoln County } \\
\quad \# 1-270\end{array}$ & $11 / 13 / 02$ & 2,633 & 380 & 13.05 & 275 & 275 & 260 to 270 & 251.95 \\
\hline 405937100183501 & $\begin{array}{l}\text { Lincoln County } \\
\quad \# 1-370\end{array}$ & $4 / 17 / 02$ & 2,633 & 380 & 12.78 & 420 & 375 & 360 to 370 & 352.22 \\
\hline 410944100192104 & $\begin{array}{l}\text { Lincoln County } \\
\quad \# 2-255\end{array}$ & $4 / 20 / 02$ & 2,929 & 770 & 208.75 & 260 & 260 & 245 to 255 & 41.25 \\
\hline 410944100192102 & $\begin{array}{l}\text { Lincoln County } \\
\quad \# 2-590\end{array}$ & $11 / 18 / 02$ & 2,929 & 770 & 210.03 & 600 & 600 & 580 to 590 & 374.97 \\
\hline 410944100192101 & $\begin{array}{l}\text { Lincoln County } \\
\quad \# 2-760\end{array}$ & $4 / 20 / 02$ & 2,929 & 770 & 209.19 & 800 & 765 & 750 to 760 & 545.81 \\
\hline 405745100174504 & $\begin{array}{l}\text { Lincoln County } \\
\quad \# 3-30\end{array}$ & $11 / 5 / 02$ & 2,614 & 395 & 7.32 & 260 & 35 & 20 to 30 & 17.48 \\
\hline 405745100174503 & $\begin{array}{l}\text { Lincoln County } \\
\quad \# 3-110\end{array}$ & $11 / 5 / 02$ & 2,614 & 395 & 7.28 & 475 & 115 & 100 to 110 & 97.54 \\
\hline 405745100174502 & $\begin{array}{l}\text { Lincoln County } \\
\quad \# 3-250\end{array}$ & $11 / 5 / 02$ & 2,614 & 395 & 7.36 & 260 & 255 & 240 to 250 & 237.58 \\
\hline 405745100174501 & $\begin{array}{l}\text { Lincoln County } \\
\quad \# 3-390\end{array}$ & $11 / 5 / 02$ & 2,614 & 395 & 7.48 & 475 & 395 & 380 to 390 & 377.45 \\
\hline 412213100425304 & $\begin{array}{l}\text { Lincoln County } \\
\quad \# 4-195\end{array}$ & $5 / 14 / 03$ & 3,075 & 700 & 104.17 & 730 & 200 & 185 to 195 & 85.83 \\
\hline 412213100425303 & $\begin{array}{l}\text { Lincoln County } \\
\quad \# 4-359\end{array}$ & $5 / 15 / 03$ & 3,075 & 700 & 107.80 & 371 & 364 & 349 to 359 & 246.20 \\
\hline 412213100425302 & $\begin{array}{l}\text { Lincoln County } \\
\quad \# 4-510\end{array}$ & $5 / 16 / 03$ & 3,075 & 700 & 107.67 & 525 & 515 & 500 to 510 & 397.33 \\
\hline 412213100425301 & $\begin{array}{l}\text { Lincoln County } \\
\quad \# 4-695\end{array}$ & $5 / 14 / 03$ & 3,075 & 700 & 107.74 & 730 & 700 & 685 to 695 & 582.26 \\
\hline 413336101101004 & $\begin{array}{l}\text { McPherson } \\
\text { County \#1-45 }\end{array}$ & $5 / 24 / 02$ & 3,326 & 775 & 8.25 & 800 & 50 & 35 to 45 & 31.75 \\
\hline 413336101101003 & $\begin{array}{l}\text { McPherson } \\
\text { County \#1-330 }\end{array}$ & $11 / 23 / 02$ & 3,326 & 775 & 21.39 & 560 & 340 & 320 to 330 & 303.61 \\
\hline 413336101101002 & $\begin{array}{l}\text { McPherson } \\
\text { County \#1-550 }\end{array}$ & $11 / 23 / 02$ & 3,326 & 775 & 21.20 & 560 & 555 & 540 to 550 & 523.80 \\
\hline 413336101101001 & $\begin{array}{l}\text { McPherson } \\
\text { County \#1-770 }\end{array}$ & $5 / 24 / 02$ & 3,326 & 775 & 22.10 & 800 & 780 & 760 to 770 & 742.90 \\
\hline
\end{tabular}


tion (XRD) analyses of sediment samples were done by George Breit (USGS, Denver). We thank Rodney Caldwell (USGS, Helena, Montana) and David Gosselin (University of Nebraska, Lincoln, Nebraska) for comments on earlier drafts of this manuscript.

\section{Description of Study Area}

The Nebraska study area includes four nested-well sites in Lincoln County, one nested-well site in McPherson County, water-table wells in Chase and Keith Counties, and a river sampling site on the Platte River in Lincoln County (fig. 2). The sampling sites north of the Platte River are located in the Sand Hills region of Nebraska, which is the largest sand dune area in the Western Hemisphere (Bleed and Flowerday, 1998). The nested-well site south of the Platte River is located in the alluvial system of the Platte River Valley.

\section{Geohydrologic Setting}

The High Plains aquifer in the study area primarily consists of alluvial sediments of the Ogallala Group, which are Miocene in age (Swinehart and Diffendal, 1998). In general, those sediments are composed of variably consolidated clay, silt, sand, and gravel. Detailed descriptions of the aquifer sediments in Lincoln and McPherson Counties, which include unconsolidated sediments and shale, siltsone, and sandstone, can be found in the reports by Goeke (2000, 2001). Other important water-bearing units of the High Plains aquifer in the study area include alluvial gravels of the Broadwater Formation (Pliocene in age) and alluvial sands and gravels in the Platte River Valley (Pleistocene and Holocene in age). In the study area, the aquifer is underlain by siltstones or clayey fine sands of the Brule Formation (Oligocene in age).

The largest saturated thicknesses in the entire High Plains aquifer occur in the Nebraska Sand Hills. In 2000, the average depth to water below land surface in the Sand Hills was about $90 \mathrm{ft}$ and the average saturated thickness was about $520 \mathrm{ft}$ (V.L. McGuire, U.S. Geological Survey, written commun., 2005). At the nested-well sites, depths to water ranged from about 10 to $200 \mathrm{ft}$ and saturated thicknesses ranged from about 400 to $725 \mathrm{ft}$ (fig. 3). Hydraulic gradients in the aquifer north of the Platte River indicate ground-water movement generally is from northwest to southeast (fig. 2). Ground-water movement south of the river generally is from west to east. The Platte River is the regional discharge area for the aquifer in the study area, but discharge to local streams such as Birdwood Creek also is important. Discharge to irrigation wells is important in the Platte River Valley and in agricultural areas south of the river (fig 4). There is relatively little irrigated agriculture in the Sand Hills.

Recharge to the northern High Plains aquifer may occur by infiltration of irrigation water, areally diffuse infiltration of precipitation, focused recharge of precipitation under depres- sions in the land surface, infiltration of stormwater runoff through streambeds, and leakage from irrigation canals and reservoirs in the Platte River Valley. Luckey and others (1986) estimated predevelopment recharge rates ranging from about 0.005 to $0.1 \mathrm{ft} /$ year on the basis of a regional model of groundwater movement; the largest recharge rates occurred in the Sand Hills and the smallest recharge rates occurred south and west of the Sand Hills. McMahon and others (2006) estimated a recharge rate of $0.2 \mathrm{ft} /$ year on the basis of tritium profiles in the unsaturated zone in a nonirrigated area of southwestern Nebraska with sandy soils.

Climate in the study area is characterized by cold and relatively dry winters and hot and relatively wet summers. Mean annual precipitation in the study area is about 20 in. (1971-2000), with about 60 percent of the precipitation occurring from May through August (High Plains Regional Climate Center, 2005). Mean annual air temperature in the study area is about $48^{\circ} \mathrm{F}\left(9^{\circ} \mathrm{C}\right)$.

\section{Land Use and Water Use}

Land in the Sand Hills is rangeland used primarily for grazing. Irrigated agriculture is the primary land use in the Platte River Valley and in areas south of the river (fig. 5). In 2002, corn (6.8 million acres), wheat (3.3 million acres), forage crops (3.2 million acres), and soybeans ( 2.9 million acres) were the primary crops grown in the northern High Plains in terms of acres planted (U.S. Department of Agriculture, 2002). Of the approximately 5.1 million acre-ft of water withdrawn from the High Plains aquifer in Nebraska in 1990, 93 percent was used for irrigation (McGuire and Sharpe, 1997). In 1990, about 12 percent of the northern High Plains area was irrigated (Qi and others, 2002). Lincoln Co. \#3 was the only nestedwell site at which an irrigated crop (corn) was grown (fig. 5).

\section{Study Methods}

In 2002 and 2003, nested monitoring wells were installed at each of five sites for the collection of water levels and water samples for chemical analysis. The well sites north of the river generally are located along a regional flow path from northwest to southeast in the aquifer (fig. 2). Water samples for chemical analysis were collected from the wells and from the Platte River by the USGS in 2003 and 2004. The following section of the report describes the methods used for the installation of monitoring wells, geophysical logging, water-level measurements, sediment-sample collection, water-sample collection, chemical analyses of sediment and water, and quality control of water-quality data.

Well installation. Monitoring wells were installed by the USGS and contract drillers in 2002 and 2003 using mud-rotary drilling techniques. In general, two boreholes were drilled at each site, and two wells were placed in each borehole using established well-installation protocols (Lapham and others, 


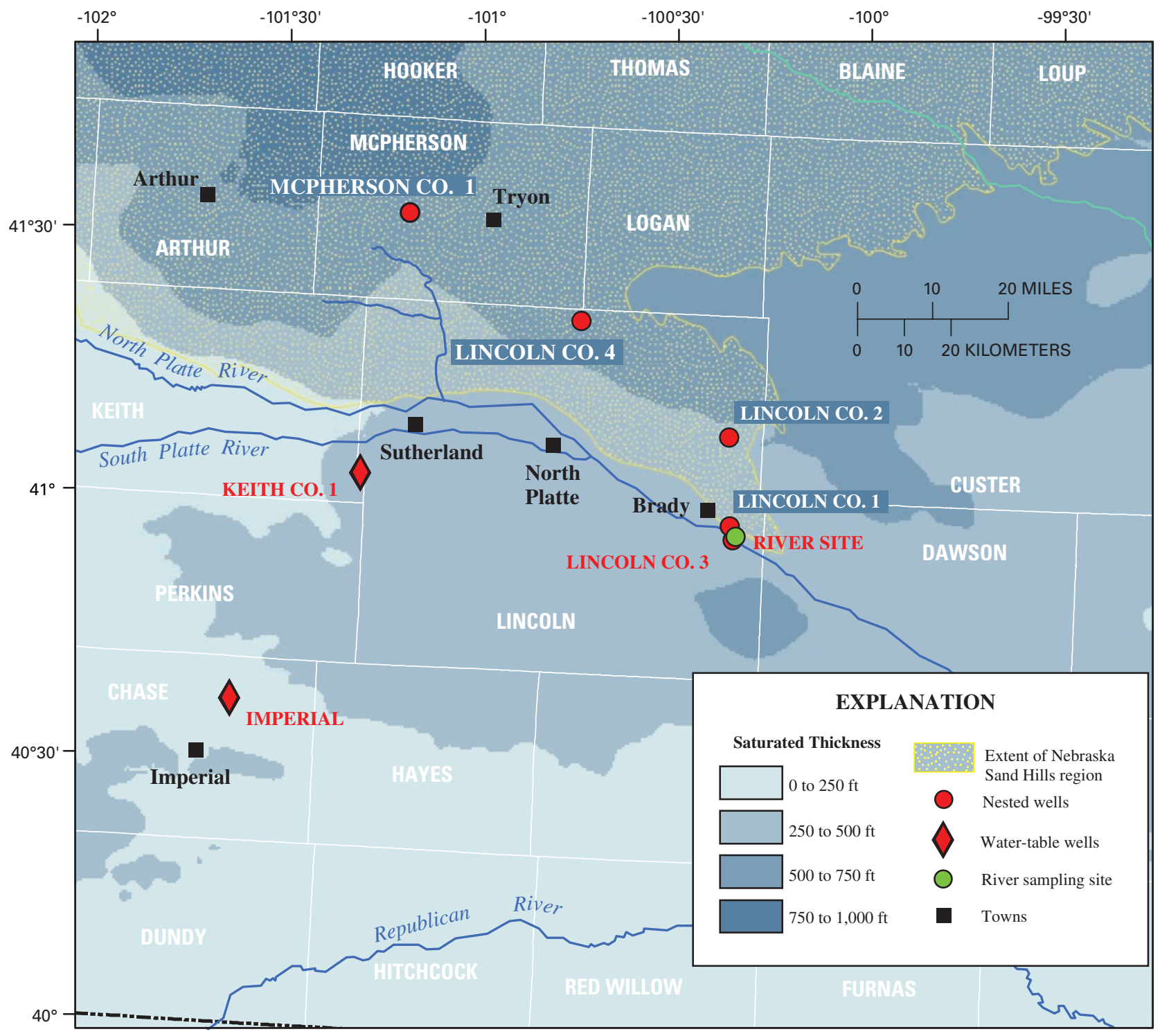

Base information from U.S. Geological Survey digital data, 1:100,000

Albers Equal-Area projection

Standard Parallels $29^{\circ} 30^{\prime}$ and $45^{\circ} 30^{\prime}$, central meridian $-96^{\circ}$

Figure 3. Saturated thickness of the northern High Plains aquifer and locations of the ground-water and surfacewater sampling sites. Thicknesses based on water-level measurements made in 2000 and the U.S. Geological Survey base-of-aquifer map (V.L. McGuire, U.S. Geological Survey, written commun., 2006; Gutentag and others, 1984). 




Figure 4. Location of registered irrigation wells in the northern High Plains and locations of the ground-water and surface-water sampling sites. 


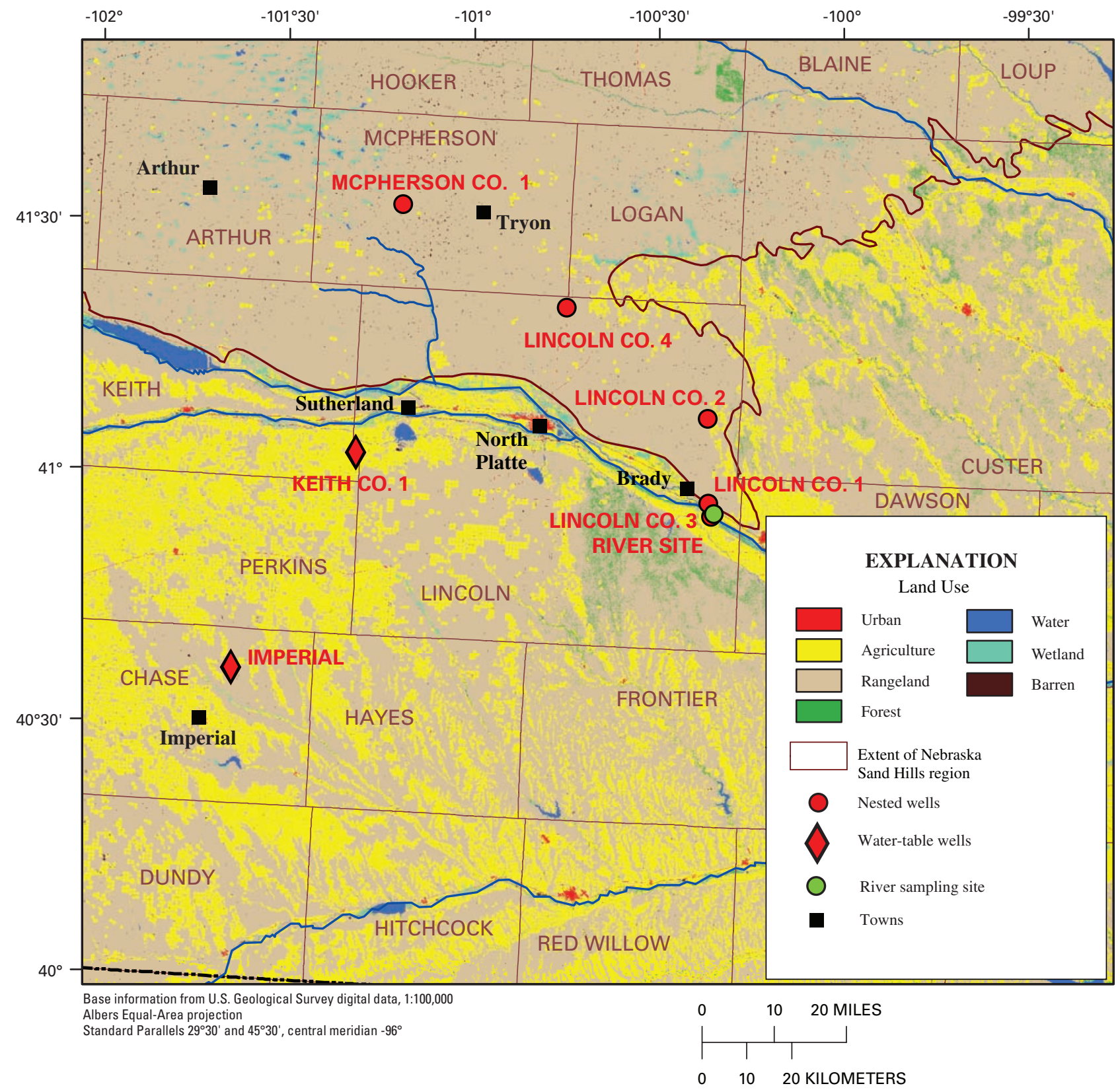

Figure 5. Land use overlying the northern High Plains aquifer and locations of the ground-water and surface-water sampling sites. Land-use data from Feagas and others (1983) collected from about 1977 to 1982. 
1995). Wells were installed by placing polyvinyl chloride (PVC) well screen and casing in the borehole after drilling to the target depth, placing a sand filter in the annular space around the well screen and bentonite plug on top of the sand filter, then sealing the annular space from the top of the plug to the bottom of the next screened interval using a high-density bentonite grout. Well screen and casing for the shallower well then were placed in the borehole, followed by a sand filter around the well screen, bentonite plug on top of the sand filter, and bentonite grout from the top of the plug to land surface. At each site, the shallowest well was installed near the water table and the deepest well was installed near the bottom of the aquifer. The wells were developed by bailing and pumping (water-table wells) or by air lifting and pumping (deeper wells) immediately after installation and again at least 1 month before sample collection. During the second well-development period, $\mathrm{pH}$, temperature, specific conductance, and turbidity of the water were monitored to determine when the well began producing water representative of the aquifer. Water was considered representative of the aquifer after a minimum of five casing volumes of water had been pumped and the change in $\mathrm{pH}$, temperature, specific conductance, and turbidity of the water between three successive measurements (taken at 30-minute intervals) was less than 5 percent. Well-construction information is listed in table 1 . The well name includes site and well-depth information, except for Imperial and Keith Co. \#1. For example, Lincoln Co. \#1-270 refers to a well at the Lincoln County \#1 site, with a maximum depth of the screened interval of $270 \mathrm{ft}$ below land surface.

Geophysical logging. Natural gamma and electrical resistivity logs were obtained for the open boreholes. Only the deepest borehole at each site was logged. The boreholes were logged by Sargent Irrigation Company, Broken Bow, Nebr.

Water-level measurements. Water levels in all wells were measured before water-sample collection by using an electric tape. In addition, water levels in the nested wells were measured monthly for 13 months. The latitude and longitude of the well locations were determined by using a Global Positioning System (GPS) with a precision of about $\pm 20 \mathrm{ft}$. The vertical position of the measuring point for each nested well was determined relative to nearby benchmarks using surveying equipment with a precision of about $0.2 \mathrm{ft}$.

Sediment-sample collection. Sediment cuttings were collected from the drilling-mud return flow every $5 \mathrm{ft}$ by using a wire-mesh screen. The cuttings were rinsed in clean tap water to remove excess drilling mud and stored in sealed canvas bags after the lithology was determined.

Water-sample collection. Ground-water and surfacewater samples were collected and processed in a mobile waterquality laboratory using methods described by Koterba and others (1995) and McMahon and others (2004a). Water was pumped from the wells by using a submersible pump made of stainless steel and Teflon. To minimize the risk of sample contamination, sample collection and preservation took place in dedicated environmental chambers consisting of clear polyethylene bags supported by tubular PVC frames. Samples from the river were collected by hand from the center of flow using Teflon bottles and then filtered and preserved in the mobile laboratory. All samples analyzed for dissolved constituents (except dissolved gases) were filtered through 0.45-micrometer capsule filters. Sampling equipment was thoroughly cleaned after sampling each site. Measurements of alkalinity, $\mathrm{pH}$, temperature, specific conductance, $\mathrm{O}_{2}$, and turbidity were done in the field using the techniques described in the USGS field manual (variously dated). Dissolved hydrogen sulfide $\left(\mathrm{H}_{2} \mathrm{~S}\right)$ also was measured in the field using a portable spectrophotometer and the methylene blue method (Hach Company, 1992).

Mineralogy and chemical analysis of sediment. Mineralogy of selected sediment samples was estimated by examination of loose grains under a petrographic microscope and XRD analysis. Analyses of the inorganic carbon, organic carbon, and total carbon contents of sediment were done at the USGS National Water Quality Laboratory in Lakewood, Colo.

Chemical analysis of water. Chemical analyses for major ions, nutrients, trace elements, DOC, and pesticides were done at the USGS National Water Quality Laboratory in Lakewood, Colo. (Fishman, 1993; Zaugg and others, 1995). The charge balance error (calculated relative to the sum of the equivalents of cations and anions) was less than 5 percent for all analyses except those from wells Lincoln Co. \#2-255 and McPherson County \#1-770, which were 6.1 and 14.7 percent, respectively. The water from well Lincoln Co. \#2-255 was relatively dilute, so a charge balance error slightly larger than 5 percent is considered acceptable for the purposes of this study. The sample from McPherson County \#1-770 was not used for geochemical modeling.

Analyses of dissolved $\mathrm{CH}_{4}, \mathrm{~N}_{2}, \mathrm{O}_{2}$, and Ar were done at the USGS Chlorofluorocarbon Laboratory in Reston, Va. (Busenberg and others, 1993; http://water.usgs.gov/lab/ dissolved-gas/, accessed on November 21, 2005). Analyses of dissolved $\mathrm{He}$ and $\mathrm{Ne}$ were done at the Lamont-Doherty Earth Observatory, Noble Gas Laboratory in Palisades, N.Y. (Ludin and others, 1998).

Analyses of $\delta^{2} \mathrm{H}\left[\mathrm{H}_{2} \mathrm{O}\right], \delta^{18} \mathrm{O}\left[\mathrm{H}_{2} \mathrm{O}\right], \delta^{15} \mathrm{~N}\left[\mathrm{NO}_{3}\right]$, $\delta^{18} \mathrm{O}\left[\mathrm{NO}_{3}\right], \delta^{15} \mathrm{~N}\left[\mathrm{~N}_{2}\right]$, and $\left.\delta^{34} \mathrm{~S}_{\mathrm{SO}_{4}}\right]$ were done at the USGS Stable Isotope Laboratory in Reston, Va. (Coplen and others, 1991; Epstein and Mayeda, 1953; Böhlke and Denver, 1995; Carmody and others, 1997; Casciotti and others, 2002; Böhlke and others, 2003). The delta " $\delta$ " notation of isotope $X$ is defined by equation 1 .

$$
\delta X=\left[\frac{R_{\text {sample }}-R_{\text {standard }}}{R_{\text {standard }}}\right] \times 1000
$$

$\mathrm{R}$ is the ratio of the rare isotope to the abundant isotope (for example, ${ }^{15} \mathrm{~N} /{ }^{14} \mathrm{~N}$ ) in the sample and standard. Values of $\left.\delta^{2} \mathrm{H}_{[} \mathrm{H}_{2} \mathrm{O}\right]$ and $\delta^{18} \mathrm{O}\left[\mathrm{H}_{2} \mathrm{O}\right]$ are reported in per mil (\%o) relative to Vienna Standard Mean Ocean Water (VSMOW), normalized to VSMOW and Standard Light Antarctic Precipitation (Coplen, 1988). The 2-sigma precisions of hydrogen $(\mathrm{H})$ and oxygen $(\mathrm{O})$ isotopic results are 2 and $0.2 \%$, respectively. 
Values of $\delta^{15} \mathrm{~N}\left[\mathrm{NO}_{3}\right]$ and $\delta^{18} \mathrm{O}\left[\mathrm{NO}_{3}\right]$ were measured using the denitrifier method (Casciotti and others, 2002), and are reported in \%o relative to atmospheric $\mathrm{N}_{2}$ and VSMOW, respectively (Böhlke and others, 2003). The 2-sigma precisions of nitrogen $(\mathrm{N})$ and $\mathrm{O}$ isotopic results are 0.5 and $1.0 \%$, respectively. Values of $\delta^{15} \mathrm{~N}\left[\mathrm{~N}_{2}\right]$ are reported with respect to atmospheric $\mathrm{N}_{2}$ and were calibrated by analyses of air $(0 \%)$. The procedures were verified by analyses of air-saturated water samples that were collected at $16^{\circ} \mathrm{C}$ under controlled laboratory conditions, prepared as samples, and yielded $\delta^{15} \mathrm{~N}\left[\mathrm{~N}_{2}\right]$ values equal to $+0.72 \pm 0.03 \%$, consistent with air-water equilibrium (Knox and others, 1992; Hübner,

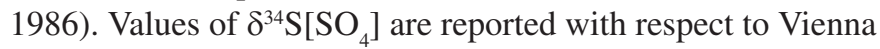
Cañon Diablo troilite (VCDT), defined by assigning a value of $-0.3 \%$ exactly (Coplen and Krouse, 1998) to IAEA-S- $1 \mathrm{Ag}_{2} \mathrm{~S}$. Analyses of IAEA-SO-5, IAEA-SO-6, and National Bureau of Standards (NBS) $127 \mathrm{BaSO}_{4}$ reference materials in the USGS laboratory yield $+0.5,-34.05$, and $+21.10 \%$, respectively. The 2 -sigma precision of sulfur (S) isotopic results is $0.4 \%$.

Analyses of ${ }^{3} \mathrm{H}$ were done at the USGS Tritium Laboratory in Menlo Park, Calif. (Thatcher and others, 1977). The average 2-sigma precision of the analyses was 0.3 tritium units (TU).

Measurements of $\delta^{13} \mathrm{C}[\mathrm{DIC}]$, reported relative to Vienna Peedee belemnite (VPDB), and ${ }^{14} \mathrm{C}[\mathrm{DIC}]$ sample preparation were done at the University of Waterloo in Ontario, Canada. Measurements of ${ }^{14} \mathrm{C}[\mathrm{DIC}]$ were done at the IsoTrace Radiocarbon Laboratory in Toronto, Canada, using accelerator mass spectrometry. Reported ${ }^{14} \mathrm{C}$ values, in percent modern carbon (pmc), are not adjusted for the difference between $-25 \%$ and the $\delta^{13} \mathrm{C}$ value of the sample.

Strontium isotope analyses were done at the USGS SolidSource Mass Spectrometry Laboratory in Menlo Park, Calif. Ratios of ${ }^{87} \mathrm{Sr} /{ }^{86} \mathrm{Sr}$ were analyzed by the positive ion thermal mass spectrometry method with a precision of 0.00002 .

Quality control of water-quality data. Quality of sample collection, processing, and analysis was checked by collecting quality-control samples. The number of qualitycontrol samples was approximately 30 percent of the number of environmental samples. Quality-control samples included field blanks, replicates, and pesticide spikes. Field blanks verified that decontamination procedures were adequate and that field and laboratory procedures did not contaminate samples. The source solution for blank samples was specially prepared organic- and inorganic-free water provided by the USGS. Blank solution was passed through all sampling equipment, and then a sample of the blank solution was collected using the same procedures used to collect environmental samples. Blank samples were collected for major ions, nutrients, trace elements, DOC, and pesticides. Replicate samples assessed the combined effects of field and laboratory procedures on measurement variability. Replicate samples were collected sequentially for all analyses. Pesticide spikes are environmental samples collected and spiked in the field with known quantities of the pesticide compounds of interest. Pesticide spike samples were used to test for analytical recoveries of the spiked compounds and for matrix interferences from the other chemicals in the water sample. Analytical recoveries are expressed in percentages of the expected concentrations.

Results from the field-blank and replicate sample analyses indicate that generally there were no systematic problems with contamination or analytical precision. In addition, all but two to the samples had ion charge-balance errors less than 5 percent. The sample from Lincoln Co. \#2-255 had a charge balance error of 6.1 percent, which was considered to be acceptable given the small concentration of dissolved solids in that sample. The sample from McPherson Co. \#1-770 had a charge balance error of 14.7 percent. It is likely that the measured field alkalinity for that sample was too low. Nevertheless, that sample was not used for mass-balance modeling because of the relatively large charge balance error. Analytical recoveries for the pesticide compounds averaged $107 \pm 30$ percent of the expected concentrations. The quality-control data are available online at http://co.water.usgs.gov/nawqa/hpgw/ datarep/TOC.html (accessed on 2/1/2007).

\section{Vertical Changes in Lithology}

Lithologic variability in the aquifer may affect water chemistry and ground-water age distributions because of its effect on rock/water interactions and rates and directions of ground-water movement. Therefore, vertical changes in lithology in the aquifer were examined using lithologic descriptions of sediment cuttings collected during drilling, borehole geophysical (gamma and resistivity) logs, XRD analyses of sediments, and elemental carbon (C) analyses. Gamma logs record the natural gamma radiation emitted by radioactive elements in sediments (Keys, 1990). Shale and clay tend to have larger proportions of these radioactive elements than sand; therefore, an increase in gamma activity recorded by gamma logs generally is attributed to increased proportions of clay in the aquifer or changes in clay mineralogy. Resistivity logs record the electrical conductivity or resistivity of the rocks and water surrounding the borehole. Electrical conductivity and resistivity are affected by the porosity, permeability, and clay content of the rocks and by the dissolved-solids concentration of the water within the rocks. In freshwater aquifers like the one studied here, decreasing resistivity readings normally indicate increasing clay content of the sediments.

The northern High Plains aquifer at the study sites is underlain by sediment of the Brule Formation that consists of dense reddish-brown siltstone and clayey fine sand that generally was characterized by relatively high natural gamma counts and decreased resistivity in geophysical logs (figs. 6 and 7). The presence of siltstone and clayey fine sand at the base of the aquifer indicates that there probably was not substantial hydrologic interaction between the High Plains aquifer and underlying water-bearing units.

Aquifer sediments in the study area were heterogeneous vertically and horizontally on the basis of natural gamma 


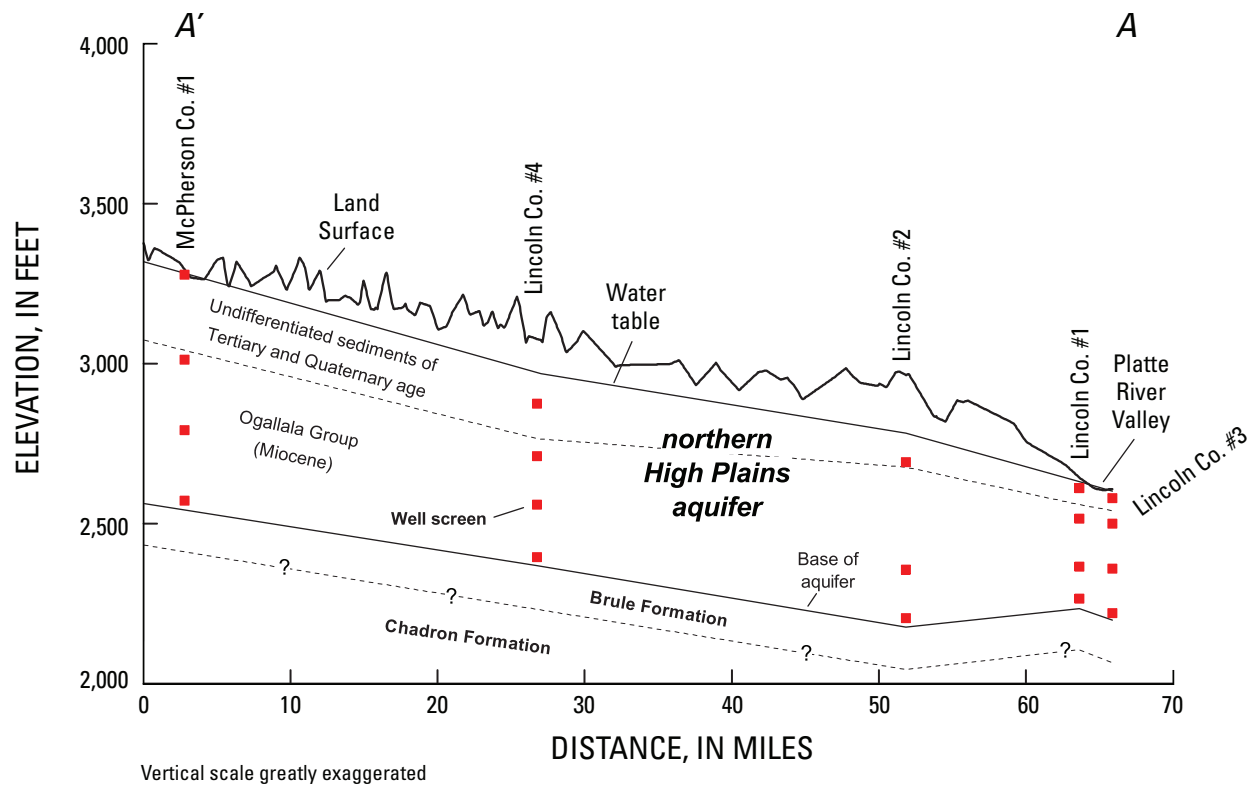

Figure 6. Geohydrologic section between nested-well sites showing locations of the monitoring-well screens. The section location A-A' is shown in figure 2.


Figure 7. Natural gamma and resistivity logs for boreholes at the nested-well sites. 
and resistivity log responses and lithologic descriptions. At the Lincoln Co. \#2 site, for example, sediment near the water table was characterized by thick grey-brown clay from about 190 to $235 \mathrm{ft}$ below land surface (fig. 7). Such a thick low-permeability unit was not observed in any of the other boreholes. The general absence of thick confining layers in the aquifer at the other locations indicates that water-table drawdowns caused by pumping large-capacity wells could draw anthropogenic contaminants near the water table deeper into the aquifer. At the present time (2005), the low density of irrigation wells in the Sand Hills (fig. 4) indicates that this process is not likely to be regionally important.

Sediments near the base of the aquifer at Lincoln Co. \#2 and at McPherson Co. \#1 were characterized by 50 - to 75 -ft-thick deposits of very coarse sand and fine gravel, whereas sediments near the base of the aquifer at the other sites were characterized by interbedded fine sandstone and siltstone. Thick intervals of relatively coarse sediment were observed at shallower depths at the other sites. At Lincoln Co. \#4, for example, intervals of coarse sand and fine gravel were present in the upper half of the aquifer at depths of about 200 and $240 \mathrm{ft}$ below land surface (fig. 7). The shallowest well at Lincoln Co. \#3 was screened in coarse sand and fine gravel of the Platte River alluvium. Coarsegrained deposits like these are primary water-bearing intervals in the aquifer; therefore, their three-dimensional distribution and connectivity in the aquifer has important consequences with respect to ground-water quality and age distributions (Bethke and Johnson, 2002; Weissmann and others, 2002). Weissmann and others (2002) showed that "young" ground-water samples can contain a large fraction of "old" water. If the young fraction in such samples contains contaminants, then it is possible that contaminant levels in those samples will increase in the future as the fraction of young water increases.

Quartz is the primary detrital mineral in the aquifer sediments (table 2). Quartz is a relatively stable mineral phase that is not readily dissolved in water; therefore, quartz dissolution is not a substantial source of dissolved solids in ground water. Volcanic ash apparently was present in one sample from the aquifer (Lincoln Co. \#4, 655 to $600 \mathrm{ft}$ ) that was analyzed by XRD, and its presence in sediment cuttings was noted several times in the lithologic logs. Volcanic ash is relatively soluble compared to quartz, and its dissolution can be a source of dissolved arsenic (As) and uranium (U). Calcite and feldspars (sodium plagioclase and potassium feldspar) generally were less abundant than quartz in the aquifer, but they are relatively reactive mineral phases. Dissolution of these minerals can be a source of dissolved calcium $\left(\mathrm{Ca}^{2+}\right)$, potassium $\left(\mathrm{K}^{+}\right)$, sodium $\left(\mathrm{Na}^{+}\right)$, bicarbonate $\left(\mathrm{HCO}_{3}^{-}\right)$, and silica $\left(\mathrm{SiO}_{2}\right)$. Calcite occurred in various forms in cuttings, including pore-filling cements in sandstone rock fragments and caliche. The $\delta^{13} \mathrm{C}$ values of bulk carbonate in sediment samples ranged from -9.1 to $-1.4 \%$ (table 3 ). Bulk carbonate in the undifferentiated sediments of Tertiary and Quaternary age was most enriched in ${ }^{13} \mathrm{C}$ and bulk carbonate in or near the Brule Formation was most depleted in ${ }^{13} \mathrm{C}$. Illite, kaolinite, and smectite were the primary clay minerals identified in the sediment samples (table 2). Smectite has a relatively large cation-exchange capacity, and cation exchange can be an important process affecting ground-water chemistry.

Only one sample (McPherson County \#1, 73 to $75 \mathrm{ft}$ ), a black siltstone from the undifferentiated sediments of Tertiary and Quaternary age overlying the Ogallala Group, contained detectable sedimentary organic carbon (table 3). Other sampled siltstones and sandstones did not contain detectable quantities of organic carbon. Despite the apparent lack of organic carbon in the sampled sediments, electron donors like sedimentary organic carbon or pyrite must have been present in the aquifer to account for some of the changes in water chemistry with depth at all of the sites (see the section "Dissolved Oxygen").

\section{Vertical Hydraulic Gradients}

Water-level data were collected at all of the nestedwell sites on about a monthly basis from December 2002 to December 2003 (fig. 8), except at the Lincoln Co. \#4 site, where measurements were made three times from August 2003 to April 2004. Measured water levels fluctuated by less than $4 \mathrm{ft}$ at all of the sites except Lincoln Co. \#2, where irrigation pumping in the area resulted in seasonal changes in water level of about $34 \mathrm{ft}$ (fig. 8). The pattern of water-level fluctuations at Lincoln Co. \#3 also indicates seasonal effects from irrigation pumping in the area. Maximum fluctuations at Lincoln Co. \#3 were about 14 times smaller than those at Lincoln Co. \#2, even though Lincoln Co. \#3 is located closer to irrigated fields than Lincoln Co. \#2. Lincoln Co. \#3 is located in the Platte River Valley; therefore, water-level declines resulting from irrigation at that site could be moderated by the river. As will be discussed in the section "Major Ions and Trace Elements," there is chemical evidence for infiltration of river water into the aquifer in the vicinity of Lincoln Co. \#3.

Vertical hydraulic gradients are based on differences in water-level elevations among nested wells and are shown in figure 8 . The gradients indicate the vertical direction of water movement in the aquifer and were calculated for vertically adjacent pairs of nested wells using equation 2 .

$$
\text { gradient }=\frac{H_{\mathrm{S}}-H_{\mathrm{d}}}{\Delta z}
$$

where $H_{\mathrm{s}}$ is water-level elevation in the shallow well, $H_{\mathrm{d}}$ is water-level elevation in the deep well, and $\Delta z$ is the distance between the two well screens. Downward gradients near the water table indicate recharge conditions and the potential for contaminants that enter the aquifer from land surface to move deeper into the aquifer. Upward hydraulic gradients near the water table indicate discharge conditions. All of the gradients near the water table were downward, except at Lincoln Co. \#3 (fig. 8). The 
Table 2. Lithologic description and mineralogy of selected drill cuttings.

[All depths are in feet below land surface; mineralogy determined by X-ray diffraction analysis; relative mineral abundances are listed in decreasing order; Na-plagioclase, sodium plagioclase; K-feldspar, potassium feldspar; ?, questionable presence.]

\begin{tabular}{|c|c|c|c|c|}
\hline $\begin{array}{l}\text { Geologic } \\
\text { unit }\end{array}$ & $\begin{array}{l}\text { Well } \\
\text { name }\end{array}$ & $\begin{array}{l}\text { Depth } \\
\text { interval } \\
\text { (feet) }\end{array}$ & Lithologic description & Mineralogy \\
\hline \multirow[t]{2}{*}{$\begin{array}{l}\text { Undifferenti- } \\
\text { ated sediments } \\
\text { of Tertiary and } \\
\text { Quaternary age }\end{array}$} & $\begin{array}{l}\text { Lincoln } \\
\text { County \#2 }\end{array}$ & 204 to 205 & $\begin{array}{l}\text { Well sorted, light reddish brown clayey fine sand to silt. Some of the } \\
\text { sample is marked by white to very pale reddish-brown cement. Few } \\
\text { plant fragments preserved. }\end{array}$ & $\begin{array}{l}\text { Whole sample: quartz, smectite, } \\
\text { illite, Na-plagioclase, K-feldspar, } \\
\text { calcite, zeolite } \\
\text { White fragments: calcite, quartz, } \\
\text { smectite, Na-plagioclase }\end{array}$ \\
\hline & $\begin{array}{l}\text { Lincoln } \\
\text { County \#4 }\end{array}$ & 190 to 195 & $\begin{array}{l}\text { Poorly sorted, coarse to medium sand. Few pebble-sized aggregates } \\
\text { cemented by sparse pale red-brown clay/carbonate. Several plant frag- } \\
\text { ments are brown and relatively fresh in appearance. }\end{array}$ & $\begin{array}{l}\text { Whole sample: quartz, Na- } \\
\text { plagioclase, K-feldspar, calcite, } \\
\text { illite }\end{array}$ \\
\hline \multirow[t]{10}{*}{ Ogallala Group } & $\begin{array}{l}\text { Lincoln } \\
\text { County \#1 }\end{array}$ & 205 to 210 & (Sample ground prior to description) & $\begin{array}{l}\text { Whole sample: quartz, Na-plag } \\
\text { clase, K-feldspar, calcite, illite, } \\
\text { amphibole? }\end{array}$ \\
\hline & $\begin{array}{l}\text { Lincoln } \\
\text { County \#2 }\end{array}$ & 735 to 740 & $\begin{array}{l}\text { Moderately sorted granules with two main components a) pale yel- } \\
\text { low-green rock fragments composed of feldspar and quartz from } \\
\text { crystalline rocks and b) aggregates of fine sand cemented by white, soft } \\
\text { intergranular cement. }\end{array}$ & $\begin{array}{l}\text { Whole sample: quartz, K-feldspar, } \\
\text { Na-plagioclase, calcite, illite } \\
\text { White aggregates of fine sand } \\
\text { calcite, quartz } \\
\text { Pale yellow-green aggregates: } \\
\text { quartz, Na-plagioclase, K-feldspar, } \\
\text { calcite, smectite, illite }\end{array}$ \\
\hline & $\begin{array}{l}\text { Lincoln } \\
\text { County \#3 }\end{array}$ & 120 to 125 & $\begin{array}{l}\text { Pale gray-green, sand, clayey silt. Abundant clay forms matrix contain- } \\
\text { ing rounded silt to medium sand. }\end{array}$ & $\begin{array}{l}\text { Whole sample: calcite, quartz, } \\
\text { Na-plagioclase, K-feldspar, } \\
\text { smectite, illite, kaolinite? }\end{array}$ \\
\hline & $\begin{array}{l}\text { Lincoln } \\
\text { County \#3 }\end{array}$ & 130 to 135 & $\begin{array}{l}\text { Poorly sorted, coarse sand to pebble-sized grains mixed with small, } \\
\text { fine-grained aggregates bound by pale brown clay intergranular fill; one } \\
\text { clast of replace wood? Soft, white, fine-grained material around more } \\
\text { massive siliceous core forms one grain. Large grains are commonly red, } \\
\text { mainly quartz and granitic to gneissic rock fragments }\end{array}$ & $\begin{array}{l}\text { Whole sample: quartz, K-feldspar, } \\
\text { Na-plagioclase, calcite, illite } \\
\text { White grain: tridymite, calcium } \\
\text { clinoptilolite, calcite }\end{array}$ \\
\hline & $\begin{array}{l}\text { Lincoln } \\
\text { County \#3 }\end{array}$ & 205 to 210 & $\begin{array}{l}\text { Poorly sorted, light brown clayey sand in large aggregates. Grains } \\
\text { range from silt to granule. Fine matrix of silt and clay is estimated to be } \\
10-20 \text { percent of the sample. }\end{array}$ & $\begin{array}{l}\text { Whole sample: quartz, calcite, } \\
\text { K-feldspar, Na-plagioclase, illite }\end{array}$ \\
\hline & $\begin{array}{l}\text { Lincoln } \\
\text { County \#3 }\end{array}$ & 225 to 230 & $\begin{array}{l}\text { Poorly sorted, medium sand to pebble sized grains, small grains are } \\
\text { cemented by white to light-brown intergranular pore filling. Some } \\
\text { grains of white cementing phase appear to be } 80 \text { percent cement, these } \\
\text { grains are massive and some have small cylindrical cavities } 0.02-0.04 \\
\text { in. diameter (rhizoliths?). Larger grains are rock fragments of granite } \\
\text { (gneiss). }\end{array}$ & $\begin{array}{l}\text { Whole sample: quartz, K-feldspar, } \\
\text { Na-plagioclase, calcite, illite } \\
\frac{\text { Grains with white cement: quartz, }}{\text { Na-plagioclase, calcite }}\end{array}$ \\
\hline & $\begin{array}{l}\text { Lincoln } \\
\text { County \#4 }\end{array}$ & 355 to 360 & $\begin{array}{l}\text { Poorly sorted coarse to fine sand. Fine sand is cemented by pale gray- } \\
\text { brown cement. A few large aggregates appear to be yellow-brown mud } \\
\text { armored by coarse to medium sand grains. A few fragments of white } \\
\text { porcelaneous aggregates. Trace plant fragments. }\end{array}$ & $\begin{array}{l}\text { Whole sample: quartz, Na-plag } \\
\text { clase, smectite } \\
\text { White grain aggregate: smectite, } \\
\text { Na-plagioclase, trace zeolite }\end{array}$ \\
\hline & $\begin{array}{l}\text { Lincoln } \\
\text { County \#4 }\end{array}$ & 500 to 505 & $\begin{array}{l}\text { Pale gray-green clayey fine sand aggregates with scattered medium } \\
\text { sand to granule-sized grains. Few plant fragments embedded in the } \\
\text { aggregates }\end{array}$ & $\begin{array}{l}\text { Whole sample: quartz, smectite, } \\
\text { Na-plagioclase, K-feldspar, calcite, } \\
\text { illite, trace amphibole? } \\
\text { White aggregate: quartz, smectite, } \\
\text { Na-plagioclase, illite }\end{array}$ \\
\hline & $\begin{array}{l}\text { Lincoln } \\
\text { County \#4 }\end{array}$ & 655 to 660 & $\begin{array}{l}\text { Very pale gray-brown mud. Examination with petrographic microscope } \\
\text { detected mainly angular isotropic, clear fragments - volcanic ash? }\end{array}$ & $\begin{array}{l}\text { Whole sample: amorphous solid, } \\
\text { quartz, plagioclase, calcite }\end{array}$ \\
\hline & $\begin{array}{l}\text { Lincoln } \\
\text { County \#4 }\end{array}$ & 690 to 695 & $\begin{array}{l}\text { Moderately sorted clayey coarse to fine sand. Sand interstices are } \\
\text { infilled with pale, brown argillaceous matrix. Sand grains are clear, red, } \\
\text { pale yellow-green. A few plant fragments are visible. }\end{array}$ & $\begin{array}{l}\text { Whole sample: quartz, Na-plagio } \\
\text { clase, K-feldspar, calcite }\end{array}$ \\
\hline \multirow[t]{2}{*}{ Brule Formation } & $\begin{array}{l}\text { Lincoln } \\
\text { County \#4 }\end{array}$ & 720 to 725 & $\begin{array}{l}\text { Well sorted, pale reddish brown, clayey fine sand. Abundant plant } \\
\text { fragments. }\end{array}$ & $\begin{array}{l}\text { Whole sample: quartz, smectite, } \\
\text { K-feldspar, Na-plagioclase, calcite, } \\
\text { illite } \\
\text { Clay-sized grains: smectite, illite }\end{array}$ \\
\hline & $\begin{array}{l}\text { McPherson } \\
\text { County \#1 }\end{array}$ & 779 to 785 & Pale red brown, poorly sorted, clayey fine sand. Trace plant fragments. & $\begin{array}{l}\text { Whole sample: quartz, smectite, Na- } \\
\text { plagioclase, K-feldspar } \\
\text { Clay-sized grains: smectite, illite, } \\
\text { chlorite? }\end{array}$ \\
\hline
\end{tabular}


Table 3. Carbon content of sediments and $\delta^{13} \mathrm{C}$ and $\delta^{18} 0$ compositions of bulk carbonate.

[Carbon contents are for size fraction less than 2 millimeters; all carbon values are estimated, so the total carbon content may not equal the sum of inorganic plus organic carbon; depths are in feet below land surface; $\mathrm{g} / \mathrm{kg}$, grams of carbon per kilogram of sediment; \%o, per mil; VPDB, Vienna Peedee belemnite; VSMOW, Vienna Standard Mean Ocean Water; --, not measured; <, less than.]

\begin{tabular}{|c|c|c|c|c|c|c|c|c|}
\hline $\begin{array}{l}\text { Geologic } \\
\text { unit }\end{array}$ & Well name & $\begin{array}{c}\text { Depth } \\
\text { interval } \\
\text { (feet) }\end{array}$ & $\begin{array}{l}\text { Lithologic } \\
\text { description }\end{array}$ & $\begin{array}{c}\text { Total } \\
\text { carbon } \\
\text { (g/kg) }\end{array}$ & $\begin{array}{c}\text { Inorganic } \\
\text { carbon } \\
(\mathrm{g} / \mathrm{kg})\end{array}$ & $\begin{array}{c}\text { Organic } \\
\text { carbon } \\
(\mathrm{g} / \mathrm{kg})\end{array}$ & $\begin{array}{c}\delta^{13} \mathrm{C} \\
\text { inorganic } \\
\text { carbon } \\
(\%, \text { VPDB })\end{array}$ & $\begin{array}{c}\delta^{18} 0, \\
\text { inorganic } \\
\text { carbon } \\
(\%, \text { VS- } \\
\text { MOW) }\end{array}$ \\
\hline \multirow{7}{*}{$\begin{array}{l}\text { Undif- } \\
\text { ferentiated } \\
\text { sediments of } \\
\text { Tertiary and } \\
\text { Quaternary } \\
\text { age }\end{array}$} & Lincoln County \#2 & $\begin{array}{l}204 \text { to } \\
205\end{array}$ & $\begin{array}{l}\text { Clayey fine sand } \\
\text { to silt }\end{array}$ & -- & -- & -- & -3.62 & 22.52 \\
\hline & Lincoln County \#2 & $\begin{array}{l}225 \text { to } \\
229\end{array}$ & $\begin{array}{l}\text { Fine to medium } \\
\text { grained clayey sand }\end{array}$ & 0.31 & $<0.2$ & $<0.2$ & -- & -- \\
\hline & Lincoln County \#4 & $\begin{array}{l}185 \text { to } \\
190\end{array}$ & Clayey siltstone & -- & -- & -- & -2.02 & 24.72 \\
\hline & Lincoln County \#4 & $\begin{array}{l}190 \text { to } \\
195\end{array}$ & $\begin{array}{l}\text { Poorly sorted, coarse } \\
\text { to medium sand }\end{array}$ & -- & -- & -- & -1.44 & 24.60 \\
\hline & $\begin{array}{l}\text { McPherson } \\
\text { County \#1 }\end{array}$ & 73 to 75 & Black siltstone & 1.72 & .52 & 1.00 & -- & -- \\
\hline & $\begin{array}{l}\text { McPherson } \\
\text { County \#1 }\end{array}$ & $\begin{array}{l}100 \text { to } \\
105\end{array}$ & Clayey siltstone & 1.42 & .64 & $<.2$ & -- & -- \\
\hline & $\begin{array}{l}\text { McPherson } \\
\text { County \#1 }\end{array}$ & $\begin{array}{l}163 \text { to } \\
165\end{array}$ & Sandy siltstone & .45 & $<.2$ & $<.2$ & -- & -- \\
\hline \multirow[t]{7}{*}{$\begin{array}{l}\text { Ogallala } \\
\text { Group }\end{array}$} & Lincoln County \#1 & $\begin{array}{l}205 \text { to } \\
210\end{array}$ & $\begin{array}{l}\text { Interbedded sand- } \\
\text { stone and siltstone }\end{array}$ & 26.62 & 25.80 & $<.2$ & -7.36 & 21.13 \\
\hline & Lincoln County \#1 & $\begin{array}{l}225 \text { to } \\
230\end{array}$ & Clayey sandstone & 21.75 & 21.00 & $<.2$ & -7.36 & 19.93 \\
\hline & Lincoln County \#3 & $\begin{array}{l}120 \text { to } \\
125\end{array}$ & Sand, clayey silt & -- & -- & -- & -7.06 & 21.08 \\
\hline & Lincoln County \#3 & $\begin{array}{l}205 \text { to } \\
210\end{array}$ & $\begin{array}{l}\text { Poorly sorted clayey } \\
\text { sand }\end{array}$ & -- & -- & -- & -7.75 & 21.04 \\
\hline & Lincoln County \#3 & $\begin{array}{l}355 \text { to } \\
360\end{array}$ & Fine sandstone & -- & -- & -- & -7.24 & 22.30 \\
\hline & Lincoln County \#4 & $\begin{array}{l}500 \text { to } \\
505\end{array}$ & Clayey fine sand & -- & -- & -- & -- & -- \\
\hline & Lincoln County \#4 & $\begin{array}{l}685 \text { to } \\
690\end{array}$ & Medium to fine sand & -- & -- & -- & -8.28 & 21.42 \\
\hline \multirow[t]{2}{*}{$\begin{array}{l}\text { Brule } \\
\text { Formation }\end{array}$} & Lincoln County \#3 & $\begin{array}{l}470 \text { to } \\
475\end{array}$ & Siltstone & -- & -- & -- & -9.10 & 25.44 \\
\hline & Lincoln County \#4 & $\begin{array}{l}720 \text { to } \\
725\end{array}$ & $\begin{array}{l}\text { Well sorted clayey } \\
\text { fine sand }\end{array}$ & 1.35 & 1.00 & $<.2$ & -- & -- \\
\hline
\end{tabular}




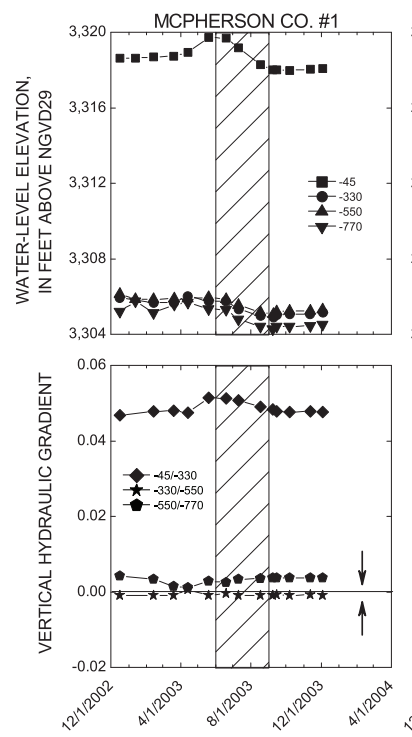

DATE
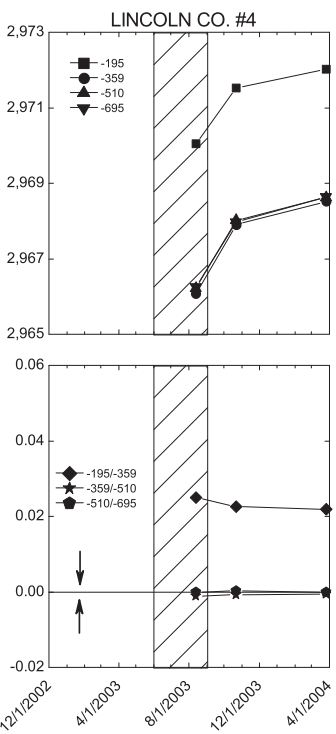

DATE
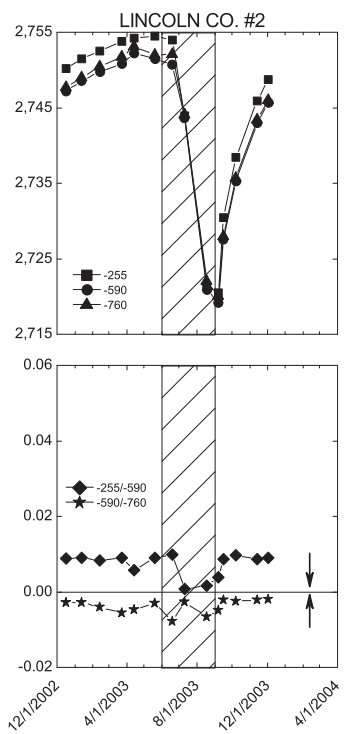

DATE
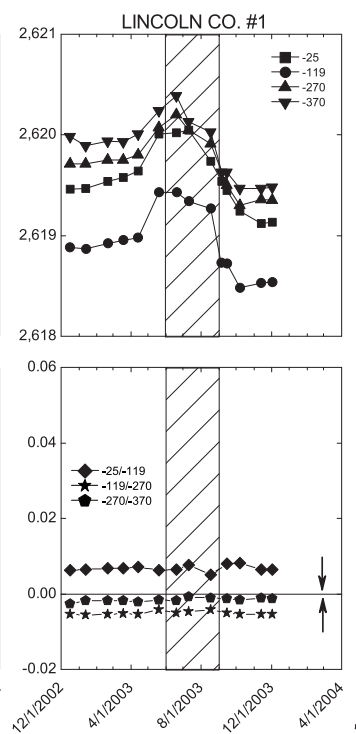

DATE
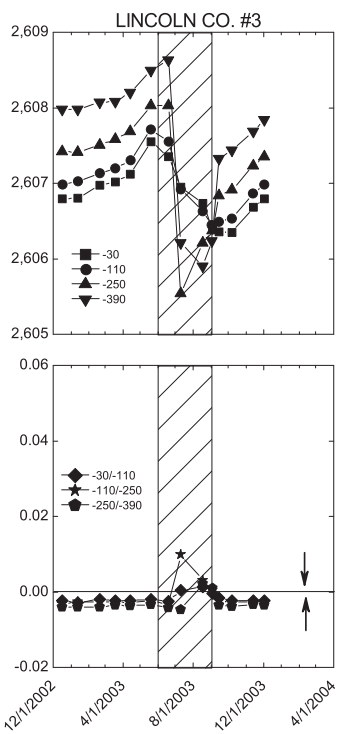

DATE

EXPLANATION

Irrigation season (June 1 through August 31)

Potential for downward ground-water movement

Potential for upward ground-water movement

Well identification number (table 1)

Figure 8. Water-level elevations and vertical hydraulic gradients at the nested wells. Vertical hydraulic gradients were calculated using equation 2 (see text).

largest downward gradient near the water table was measured at McPherson Co. \#1, the site located farthest from the Platte River, and the downward gradients in other wells decreased toward the river along geohydrologic section A-A'. Gradients near the water table at Lincoln Co. \#3 were upward, except during the irrigation season when the gradients were reversed. Upward gradients are expected at Lincoln Co. \#3 because of its location in the Platte River Valley, which is the regional ground-water discharge area for the aquifer. Lincoln Co. \#1 is located just above the valley, and gradients indicate that deep ground water was moving upward in that area even though a small downward gradient existed near the water table.

Irrigation pumping in the vicinity of Lincoln Co. \#3 effectively reversed hydraulic gradients at that site for 1 to 3 months (fig. 8). During that time period, the direction of ground-water movement was changed from the natural condition of upward movement to a condition of downward movement. This reversal in flow direction has the potential to draw contaminants near the water table deeper into the aquifer. A reversal in gradient was not observed at Lincoln Co. \#2 even though water levels declined by as much as $34 \mathrm{ft}$ during the irrigation season. A gradient reversal did not occur at that site because water levels at each of the three monitored depths in the aquifer responded in a similar fashion to irrigation pumping, indicating that the aquifer may be hydraulically well connected in the vertical direction. This is in sharp contrast to water-level responses to pumping observed in areas of the High Plains aquifer in Kansas where water-level declines near the water table were much less than those deeper in the aquifer (McMahon, 2001). The Kansas and Lincoln Co. \#2 sites had similar saturated thicknesses ( 500 ft) and water-level declines (greater than $30 \mathrm{ft}$ ). At that Kansas site, several relatively thick clay layers in the aquifer helped to isolate individual waterbearing sand and gravel units. The apparent vertical connectivity of water-bearing units at Lincoln Co. \#2, in addition to large seasonal water-level declines, could enhance downward movement of contaminants in the aquifer if they were to reach the water table.

\section{Vertical Gradients in Water Chemistry}

Concentrations of dissolved constituents varied with depth in the northern High Plains aquifer. Some of those changes were the result of spatial and temporal variability in inputs from sources at the land surface and others were the result of chemical reactions along flow paths in the aquifer. This section presents chemical data and discusses processes that might account for the observed vertical gradients in water chemistry. 


\section{Tritium}

Tritium is a radioactive isotope of hydrogen with a halflife of about 12.3 years. It is an excellent tracer of water movement because it substitutes for stable hydrogen isotopes in the water molecule. Because ${ }^{3} \mathrm{H}$ is radioactive, its concentration in ground water decreases over time because of radioactive decay. In general, ${ }^{3} \mathrm{H}$ in ground water originates from precipitation. Before the onset of atmospheric testing of nuclear weapons in 1953 (prebomb), the ${ }^{3} \mathrm{H}$ content of precipitation in the central United States probably ranged from about 3 to 8 TU (Kaufman and Libby, 1954; Thatcher, 1962). As a result of radioactive decay, ground water derived from precipitation that fell before 1953 would have contained no more than about 0.5 $\mathrm{TU}$ of ${ }^{3} \mathrm{H}$ in 2003. The ${ }^{3} \mathrm{H}$ content of precipitation increased substantially after the onset of atmospheric nuclear weapons testing but has slowly decreased from its peak in the early 1960s. Even with the variability in ${ }^{3} \mathrm{H}$ content of precipitation over time, ground water totally derived from precipitation that fell since 1953 (postbomb) contained more than $0.5 \mathrm{TU}$ in 2003.

Tritium was detected in water from three of the five nested wells screened near the water table (Lincoln Co. \#1-25, Lincoln Co. \#3-30, McPherson Co. \#1-45) (table 4). The depth to water at the time of sampling at each of those three sites was less than $13 \mathrm{ft}$ (table 1). The two nested wells screened near the water table that produced water without detectable ${ }^{3} \mathrm{H}$ had depths to water greater than $100 \mathrm{ft}$ (Lincoln Co. \#2-255, Lincoln Co. \#4-195). The data indicate that water moved from the land surface to the relatively shallow water tables in less than about 50 years, whereas transits times of water through the thicker unsaturated zones were greater than 50 years. None of the deeper nested wells produced water with detectable ${ }^{3} \mathrm{H}$ concentrations, except for McPherson Co. \#1-770 (see discussion below; table 4), indicating that water from those deeper wells was recharged prior to 1953 . The tritium data show that under undisturbed conditions, the aquifer contained a relatively thin layer of recently recharged ground water (less than 50 years) overlying a thicker layer of older ground water. Radiocarbon dating of dissolved inorganic carbon (DIC) was used to estimate ground-water ages in those deeper wells to obtain better resolution of vertical gradients in ground-water age in the aquifer. The radiocarbon age estimates are discussed in the section "Vertical Gradients in Ground-Water Age."

The presence of postbomb ${ }^{3} \mathrm{H}$ in water from McPherson Co. \#1-770 is evidence for downward leakage of shallow ground water in that well. Subsequent investigations using a downhole camera and packers showed that a leaking joint in the PVC casing at a depth of about $40 \mathrm{ft}$ below land surface was allowing shallow ground water into the well at a rate of about $0.06 \mathrm{gal} / \mathrm{min}$. Water from McPherson Co. \#1-770 may have contained about 30 percent shallow ground water at the time of sampling on the basis of ${ }^{3} \mathrm{H}$ concentrations measured in water from that well $(1.8 \mathrm{TU})$ and from the water-table well at that site (McPherson Co. \#1-45, 5.8 TU) and assuming that background ground water at the depth of the McPherson Co. \#1-770 screen did not contain ${ }^{3} \mathrm{H}$.

\section{Dissolved Oxygen}

Some chemicals of environmental concern in the aquifer, such as nitrate $\left(\mathrm{NO}_{3}^{-}\right), \mathrm{U}$, and sulfate $\left(\mathrm{SO}_{4}{ }^{2-}\right)$, may be reduced to less oxidized forms by naturally occurring microorganisms under suboxic to anoxic conditions. Microbial reduction of these chemicals is beneficial because it may convert the chemicals into less soluble or less toxic forms. Reducing conditions, however, also may lead to the mobilization of toxic elements like As or nuisance elements like iron (Fe). In oxygenated ground water, microorganisms may oxidize some chemicals, such as atrazine, ultimately to carbon dioxide $\left(\mathrm{CO}_{2}\right)$ (McMahon and others, 1992). The role of dissolved $\mathrm{O}_{2}$ in microbial processes and ground-water chemistry makes measuring its distribution in ground water important if the fate of potentially harmful chemicals is to be understood.

Concentrations of $\mathrm{O}_{2}$ in water from the nested wells ranged from less than 0.5 to $7.8 \mathrm{mg} / \mathrm{L}$ (Appendix 1). For the sites located in the Sand Hills, $\mathrm{O}_{2}$ concentrations generally were largest at the water table and decreased with depth (for example, see $\mathrm{O}_{2}$ data for Lincoln Co. \#4 in Appendix 1). In the Sand Hills, $\mathrm{O}_{2}$ concentrations were less than $0.5 \mathrm{mg} / \mathrm{L}$ in all of the deep wells, except for Lincoln Co.\#1-370 and Lincoln Co. \#2-760. These data indicate that sufficient supplies of electron donors, such as organic carbon or sulfide minerals, were present in the aquifer to support microbial reduction of $\mathrm{O}_{2}$ within a relatively short travel distance from the water table. The presence of $\mathrm{O}_{2}$ in water from Lincoln Co. \#1-370 and Lincoln Co. \#2-760 could indicate shallow ground water mixing in the well bore at those sites. If so, the small ${ }^{14} \mathrm{C}$ concentrations and lack of detectable ${ }^{3} \mathrm{H}$ in water from those wells indicate that the fraction of shallow water in those samples could be small.

Profiles of dissolved $\mathrm{O}_{2}$ concentrations in ground water from Lincoln Co. \#3 were distinctly different from those at the sites located in the Sand Hills north of the river. Concentrations of $\mathrm{O}_{2}$ were larger than $2.5 \mathrm{mg} / \mathrm{L}$ in water from each of the Lincoln Co. \#3 wells (Appendix 1), indicating the presence of less reducing conditions south of the river compared to conditions north of the river. The water-table contour map in figure 2 indicates that water in the Lincoln Co. \#3 wells was recharged in areas south of the river, possibly in western Lincoln County and parts of Keith and Perkins Counties. The aquifer in those areas primarily consists of sediments of the Ogallala Group (Diffendal and Goeke, 2000; Dreeszen, 2000; Goeke, 2001), as opposed to the combination of Ogallala Group and younger sediments north of the river (fig. 6). Those younger sediments overlying the Ogallala Group apparently contain a sufficient supply of electron donors to support relatively rapid $\mathrm{O}_{2}$ reduction. Swinehart (1998) noted the presence of organic carbon-rich fine sands in the Sand Hills north of the study area and an organic carbon-rich siltstone was recovered from the McPherson Co. \#1 bore hole (table 3). The presence 
Table 4. Isotopic data from sampled monitoring wells screened in the northern High Plains aquifer and from the Platte River near

Brady, Nebraska.

[Multiple entries indicate replicate samples or measurements; TU, tritium units; \%o, per mil; VSMOW, Vienna Standard Mean Ocean Water; VPDB, Vienna Peedee Belemnite; VCDT, Vienna Cañon Diablo Troilite; pmc, percent modern carbon; <, less than; --, no data; nr, near]

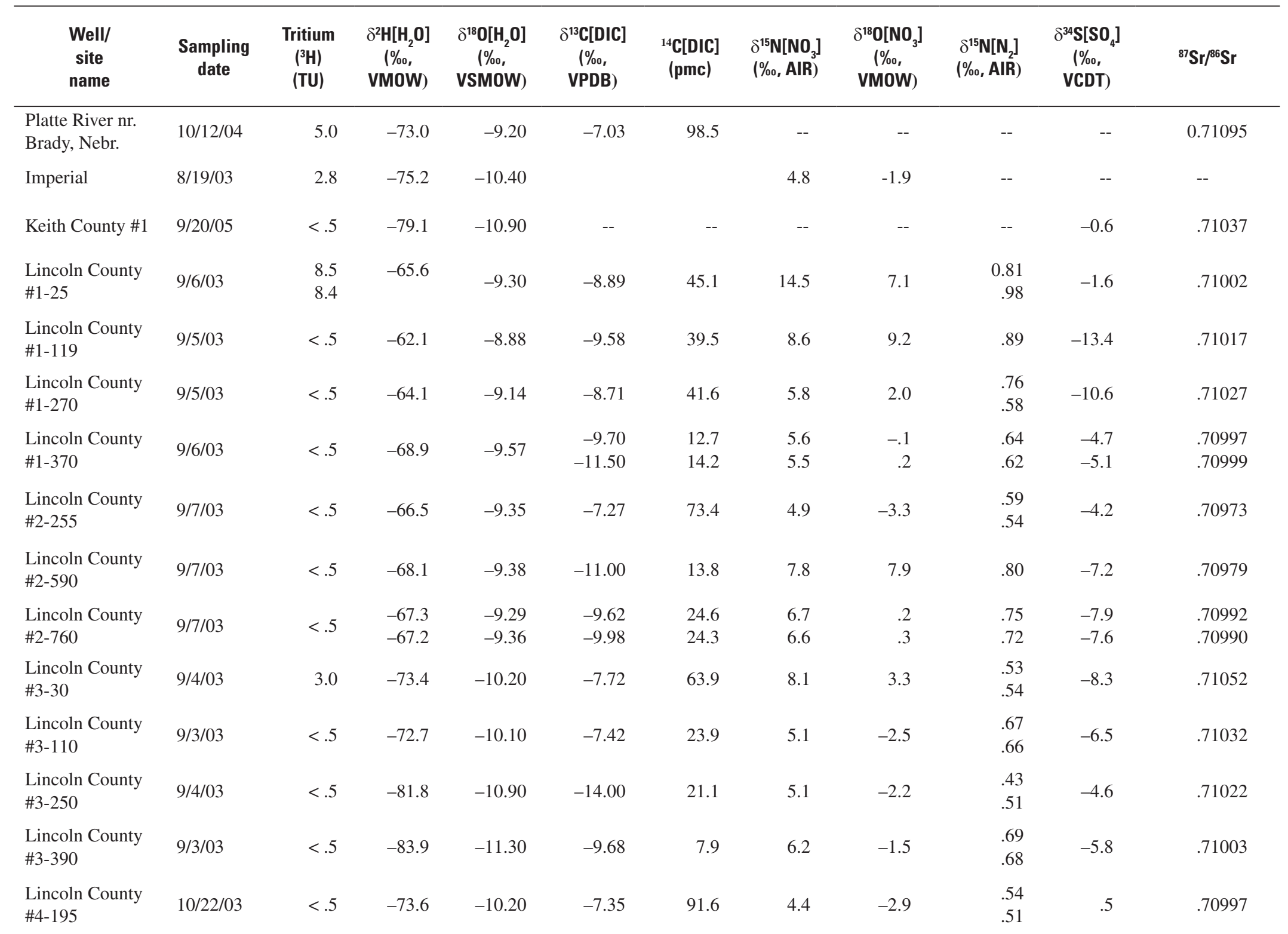


Table 4. Isotopic data from sampled monitoring wells screened in the northern High Plains aquifer and from the Platte River near Brady, Nebraska.—Continued

[Multiple entries indicate replicate samples or measurements; TU, tritium units; \%, per mil; VSMOW, Vienna Standard Mean Ocean Water; VPDB, Vienna Peedee Belemnite; VCDT, Vienna Cañon Diablo Troilite; pmc, percent modern carbon; <, less than; --, no data]

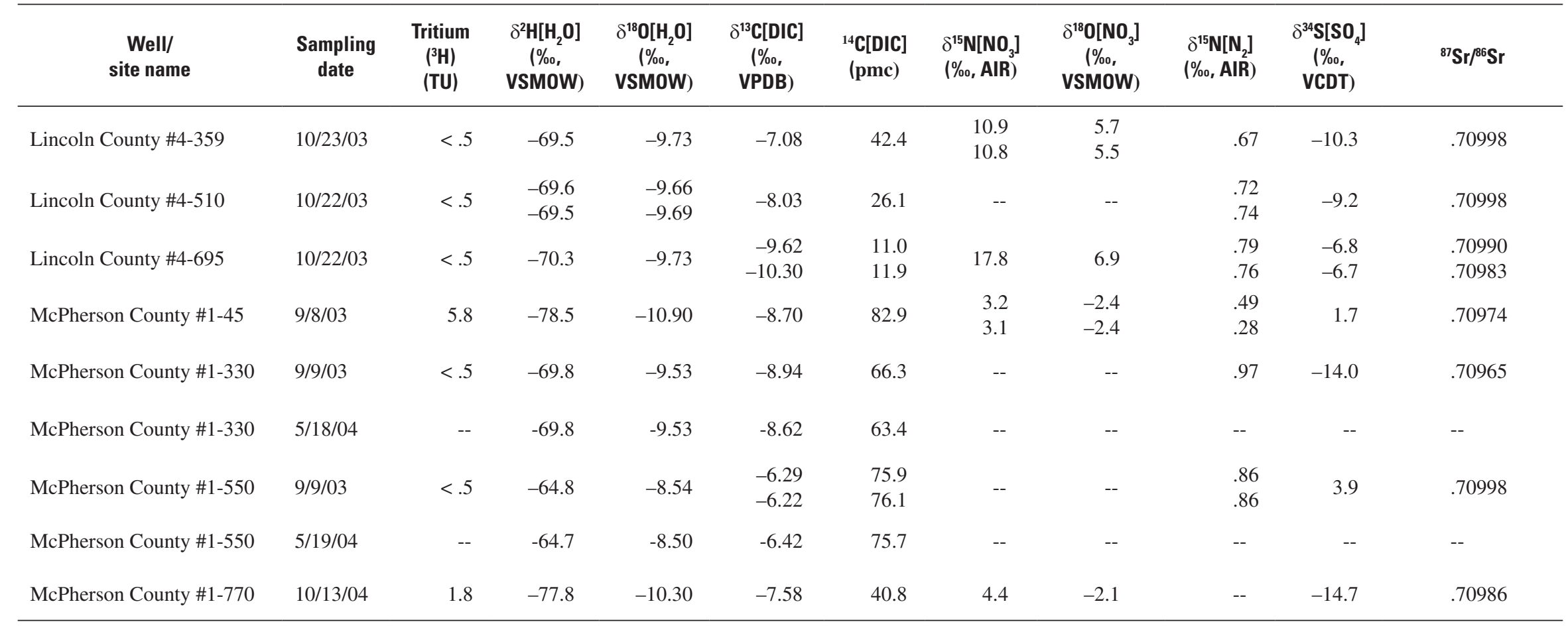


of relatively reducing conditions in the aquifer north of the river, but not south of the river, has important implications with respect to spatial variability in the persistence of contaminants such as $\mathrm{NO}_{3}^{-}$in the aquifer. This is discussed in the section "Nitrate."

\section{Major Ions and Trace Elements}

Dissolved-solids concentrations in undisturbed aquifers usually increase with depth below the water table as the residence time of ground water increases and rock/water reactions progress. That trend is evident in water samples from Lincoln Co. \#4 (fig. 9), the site north of the river that is considered to be the most representative of undisturbed conditions in the aquifer. Dissolved-solids concentrations in water from that site increased from $118 \mathrm{mg} / \mathrm{L}$ near the water table to $263 \mathrm{mg} / \mathrm{L}$ near the base of the aquifer. Much of the increase in dissolved solids with depth is accounted for by increases in concentrations of dissolved $\mathrm{Ca}^{2+}, \mathrm{Na}^{+}$, alkalinity, $\mathrm{SO}_{4}{ }^{2-}$, and $\mathrm{SiO}_{2}$ (fig. 9). In general, the chemistry of ground water throughout the aquifer was of high quality. None of the approximately 90 chemical constituents analyzed in each sample exceeded primary drinking-water standards (U.S. Environmental Protection Agency, 2006). Water samples collected from undisturbed parts of the aquifer were primarily of a $\mathrm{Ca}^{2+}-\mathrm{HCO}_{3}^{-}$type, although a few samples were of a $\mathrm{Ca}^{2+}-\mathrm{Na}^{+}-\mathrm{HCO}_{3}^{-}$type. Concentrations of most constituents at the base of the aquifer also were relatively small, indicating that interactions with the underlying geologic formations probably had only small effects on water quality in the aquifer. This was not always the case in the central and southern High Plains aquifers, where interactions with underlying geologic formations containing nonpotable water adversely affected water quality in the aquifer (McMahon and others, 2004a, b).

Agricultural activity at the land surface can increase the concentration of dissolved solids in recharge above what would be expected under natural conditions (Böhlke, 2002; McMahon and others, 2004b), resulting in a reversed gradient in dissolved-solids concentrations near the water table. Irrigated agriculture appears to have produced that effect at the Lincoln Co. \#3 site. At that site, the concentration of dissolved solids in water from the well screened near the water table $(433 \mathrm{mg} / \mathrm{L})$ was larger than the concentration in water from the next deepest well (286 mg/L) (fig. 9). The presence of modern recharge at that site is evident from postbomb ${ }^{3} \mathrm{H}$ in water from the water-table well, Lincoln Co. \#3-30, and effects from agriculture also are evident from the detection of a pesticide compound (deethylatrazine) and relatively large concentrations of $\mathrm{NO}_{3}^{-}, \mathrm{SO}_{4}{ }^{2-}$, and chloride $\left(\mathrm{Cl}^{-}\right)$(table 4 and Appendix 1).

Given that $\mathrm{HCO}_{3}^{-}$accounted for 84 percent, on average, of the anion equivalents in the water samples, concentrations of selected dissolved constituents were plotted relative to concentrations of DIC to better understand what geochemical reactions or other processes in the aquifer might account for the observed changes in dissolved-constituent concentrations (fig. 10). Dissolved inorganic carbon was calculated from
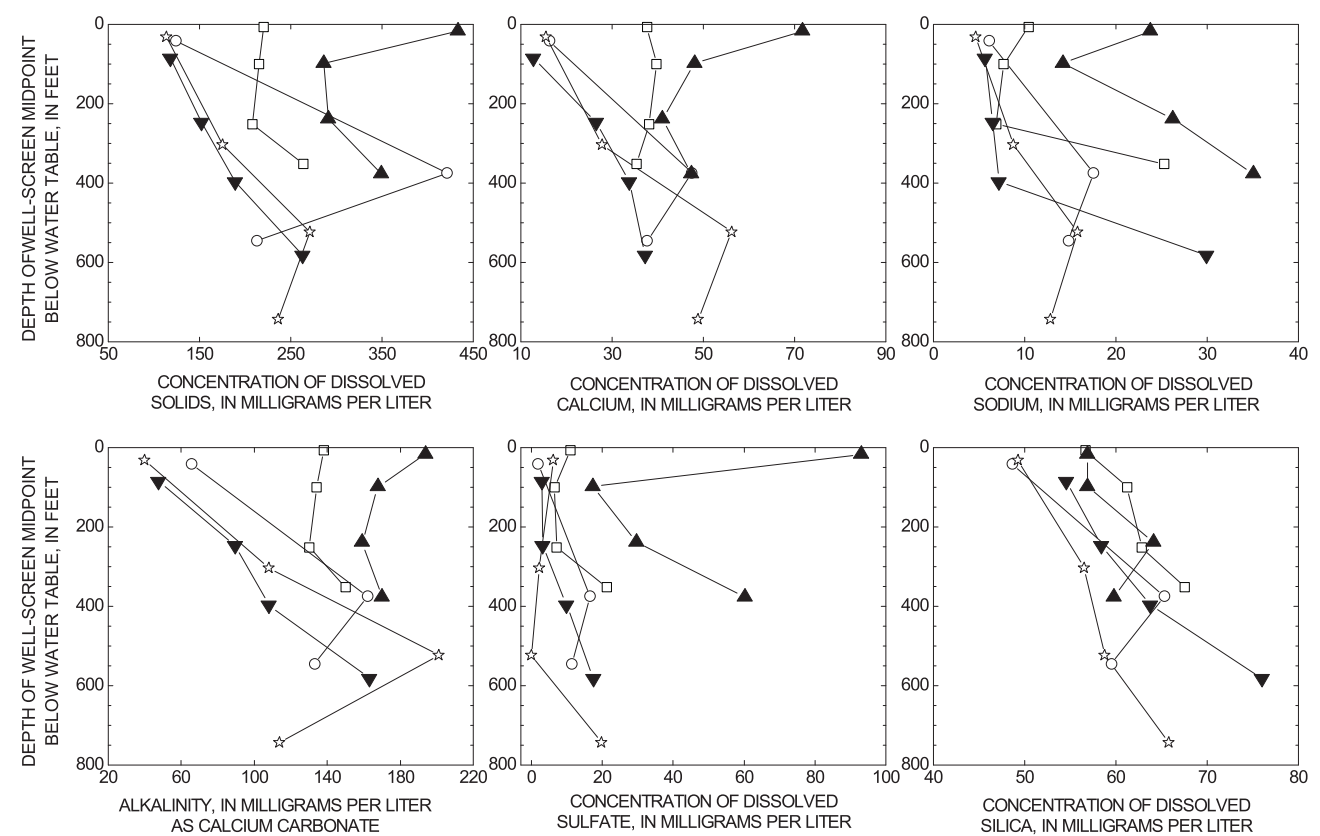

EXPLANATION

$\square-$ Lincoln Co.\#1 $-\bigcirc-$ Lincoln Co.\#2 $\quad-\quad$ Lincoln Co.\#3 $\rightarrow \boldsymbol{\nabla}$ Lincoln Co.\#4 $\rightarrow-$ McPherson Co.\#1

Figure 9. Concentrations of selected dissolved constituents in relation to well-screen depth below the water table. 
alkalinity and $\mathrm{pH}$ data using the geochemical code NETPATH (Plummer and others, 1994). In those plots, concentrations are reported on a molar basis to facilitate comparisons between concentrations and chemical reactions that might account for them, as discussed below. Dissolved $\mathrm{Ca}^{2+}$ concentrations were strongly correlated to DIC concentrations. Calcite dissolution in the presence of $\mathrm{CO}_{2}$ is one possible reaction that could produce a positive correlation between $\mathrm{Ca}^{2+}$ and DIC concentrations

(eq. 3).

$$
\begin{aligned}
& \mathrm{CaCO}_{3} \text { (calcite) }+\mathrm{H}_{2} \mathrm{O}+\mathrm{CO}_{2}= \\
& \mathrm{Ca}^{2+}+2 \mathrm{HCO}_{3}^{-}
\end{aligned}
$$

Calcite was relatively abundant in the aquifer (table 2), and $\mathrm{CO}_{2}$ could be produced from the coupled oxidation of organic carbon and reduction of dissolved $\mathrm{O}_{2}$. Other electron acceptors, such as $\mathrm{NO}_{3}^{-}$and $\mathrm{SO}_{4}{ }^{2-}$, are discussed later in the report. Equation 3 produces $\mathrm{Ca}^{2+}$ and DIC in a molar ratio of $1: 2$. The data actually plot along a line with a 1:3 slope (fig. 10), indicating that the water is depleted in $\mathrm{Ca}^{2+}$ relative to what would be expected on the basis of equation 3. This apparent depletion could result from $\mathrm{Ca}^{2+}$ uptake from solution or from other reactions that also contributed $\mathrm{Ca}^{2+}$ and DIC to solution in ratios other than 1:2. One possible sink for dissolved $\mathrm{Ca}^{2+}$ is cation exchange on clay minerals, such as smectite (table 2), in the aquifer. The composition of exchangeable cations on the clays is unknown, but if $\mathrm{Na}^{+}$is abundant on the exchange sites, then a reaction similar to equation 4 could account for the apparent $\mathrm{Ca}^{2+}$ depletion.

$$
\mathrm{Ca}^{2+}+2 \mathrm{Na}-\text { clay }=2 \mathrm{Na}^{+}+\mathrm{Ca}-\text { clay }
$$

Concentrations of dissolved $\mathrm{Na}^{+}$and $\mathrm{SiO}_{2}$ also exhibit generally positive correlations with DIC concentrations (fig. 10). Those relations could result, in part, from dissolution of sodium-bearing silicate minerals. The XRD analyses show that sodium plagioclase was relatively abundant in the aquifer (table 2). Dissolution of albite (pure sodium plagioclase) or sodium plagioclase (also containing calcium) in the presence of $\mathrm{CO}_{2}$ could produce positive $\mathrm{Na}^{+}$-DIC and $\mathrm{SiO}_{2}$-DIC correlations (eqs. 5 and 6).

$$
\begin{gathered}
4 \mathrm{NaAlSi}_{3} \mathrm{O}_{8}(\text { albite })+6 \mathrm{H}_{2} \mathrm{O}+4 \mathrm{CO}_{2}=2 \mathrm{Al}_{2} \mathrm{Si}_{2} \mathrm{O}_{5}(\mathrm{OH})_{4} \\
(\text { kaolinite })+8 \mathrm{SiO}_{2}+4 \mathrm{Na}^{+}+4 \mathrm{HCO}_{3}^{-} \\
1.77 \mathrm{Na}_{0.62} \mathrm{Ca}_{0.38} \mathrm{Al}_{1.38} \mathrm{Si}_{2.62} \mathrm{O}_{8}(\text { sodium plagioclase })+ \\
3.67 \mathrm{H}_{2} \mathrm{O}+2.44 \mathrm{CO}_{2}=1.23 \mathrm{Al}_{2} \mathrm{Si}_{2} \mathrm{O}_{5}(\mathrm{OH})_{4}(\text { kaolinite })+ \\
2.20 \mathrm{SiO}_{2}+1.10 \mathrm{Na}^{+}+0.67 \mathrm{Ca}^{2+}+2.44 \mathrm{HCO}_{3}^{-}
\end{gathered}
$$

The combined reactions described by equations 3 and 6 would add $\mathrm{Ca}^{2+}$ and DIC to solution in a ratio of $1: 2.7$, which is close to the observed ratio of 1:3 (fig. 10). The small additional $\mathrm{Ca}^{2+}$ depletion could be accounted for by cation exchange. The ${ }^{87} \mathrm{Sr} /{ }^{86} \mathrm{Sr}$ ratios of dissolved strontium $\left(\mathrm{Sr}^{2+}\right)$ in ground water, excluding Lincoln Co. \#3-30, ranged from 0.70965 to 0.71052 (table 4). Those values could be consistent with the interpre- tation that the dissolved $\mathrm{Sr}^{2+}$ was derived from plagioclase dissolution (Gosselin and others, 1997b; McNutt, 2000). More precise information on the chemical and isotopic compositions of the carbonate and silicate minerals and exchangeable cation compositions, in addition to petrographic observations of mineral dissolution or precipitation, would help to refine our understanding of geochemical processes in the aquifer. Nevertheless, the reactions presented here are qualitatively consistent with the measured ground-water chemistry and the trends in saturation indexes for calcite and albite (fig. 10; Appendix 2). Saturation index is defined by equation 7 :

$$
\text { Saturation index }=\frac{I A P}{K_{\mathrm{eq}}}
$$

where, IAP is the ion activity product for mineral dissolution and $K_{\mathrm{eq}}$ is the equilibrium constant for mineral dissolution (Stumm and Morgan, 1981). Saturation indexes were calculated from chemical data in Appendix 1 using the geochemical code NETPATH (Plummer and others, 1994). The saturation indexes in figure 10 show that calcite and albite have the potential to dissolve along flow paths from the recharge areas (small DIC concentrations in figure 10) to the downgradient wells (large DIC concentrations in figure 10).

Other processes that may affect water chemistry in the aquifer are mixing with surface water, sulfide-mineral oxidation, $\mathrm{SO}_{4}^{2-}$ reduction, and possibly evaporation. Mixing, as used in this report, refers to the convergence of flow paths from different recharge sources. At Lincoln Co. \#3, $\mathrm{Sr}^{2+}$ concentrations and isotopic compositions indicate that mixing occurred where flow paths originating in regional recharge areas south of the river converged with flow paths that originated at the river as a result of induced infiltration (fig. 11). Water from Lincoln Co. \#3-30 may have contained about 30 percent river water on the basis of the $\mathrm{Sr}^{2+}$ data. The composition of water from Lincoln Co. \#3-110 was used to represent regional ground water because the hydraulic-head data show Lincoln Co. \#3-110 to be upgradient from Lincoln Co. \#3-30 (fig. 8). The elevated $\mathrm{SO}_{4}{ }^{2-}$ and $\mathrm{U}$ concentrations in water from Lincoln Co. \#3-30 provide additional evidence for mixing with river water at that site (Appendix 1). Excluding water from Lincoln Co. \#3-30, the $\mathrm{Sr}^{2+}$ data for the other water samples are consistent with chemical evolution in the aquifer along flow paths from the regional recharge areas (fig. 11).

Sulfate concentrations increased with depth at some of the nested well sites (fig. 9). The concentration increases generally were accompanied by decreases in the $\delta^{34} \mathrm{~S}$ values for $\mathrm{SO}_{4}^{2-}$ (fig. 12). For example, the median concentration and isotopic composition of $\mathrm{SO}_{4}{ }^{2-}$ in recharge waters north of the Platte River were $2.4 \mathrm{mg} / \mathrm{L}$ and $-0.53 \%$, respectively, whereas the median concentration and isotopic composition of $\mathrm{SO}_{4}{ }^{2-}$ in the downgradient waters were $11 \mathrm{mg} / \mathrm{L}$ and $-9.8 \%$, excluding the sample from McPherson Co. \#1-550 (fig. 12). This relation between $\mathrm{SO}_{4}{ }^{2-}$ concentration and $\delta^{34} \mathrm{~S}$ values indicates that the increase in $\mathrm{SO}_{4}{ }^{2-}$ concentrations with depth may be related to the oxidation of sulfide minerals, such as pyrite, a source of ${ }^{34} \mathrm{~S}$-depleted sulfur (Krouse and Mayer, 

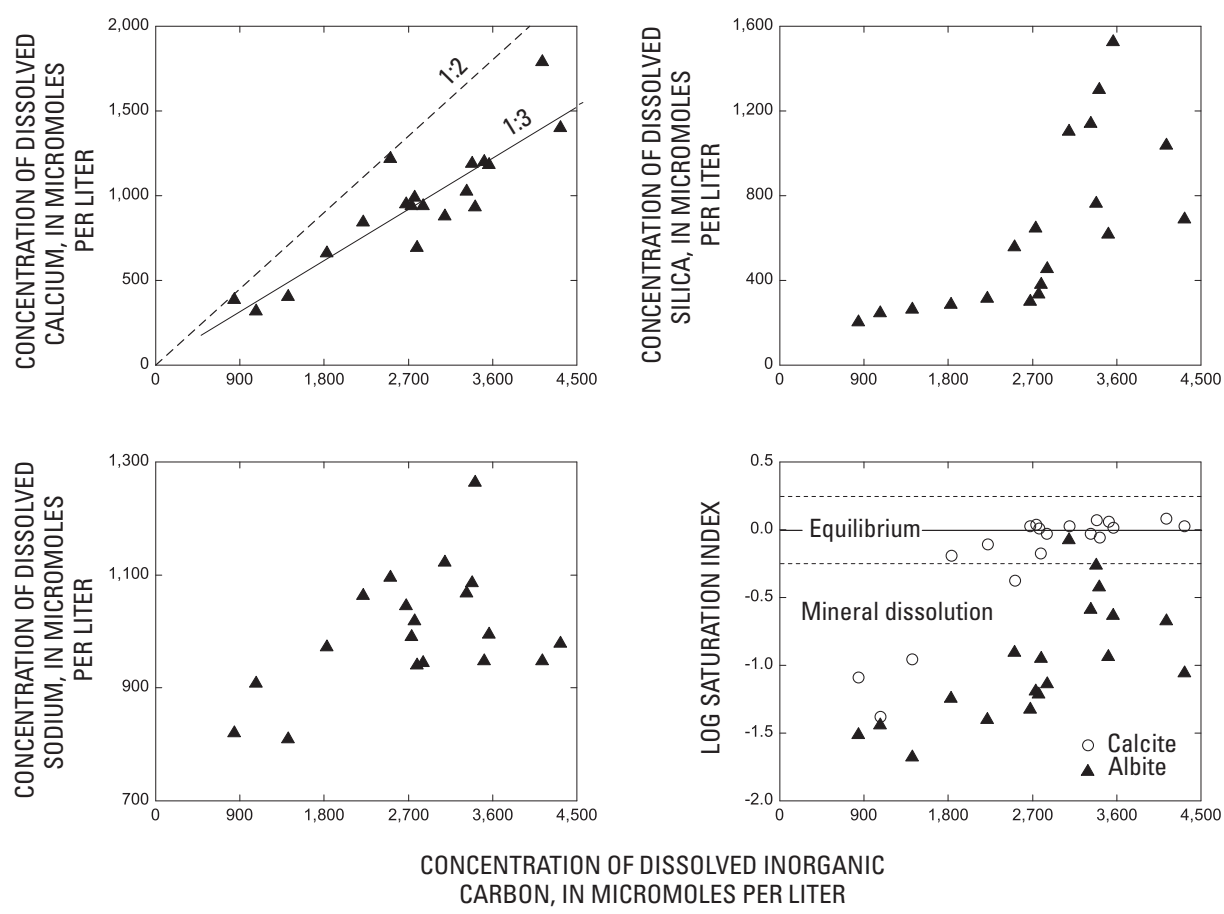

Figure 10. Concentrations of selected dissolved constituents and mineral saturation indexes in relation to concentrations of dissolved inorganic carbon in water from the nested wells.

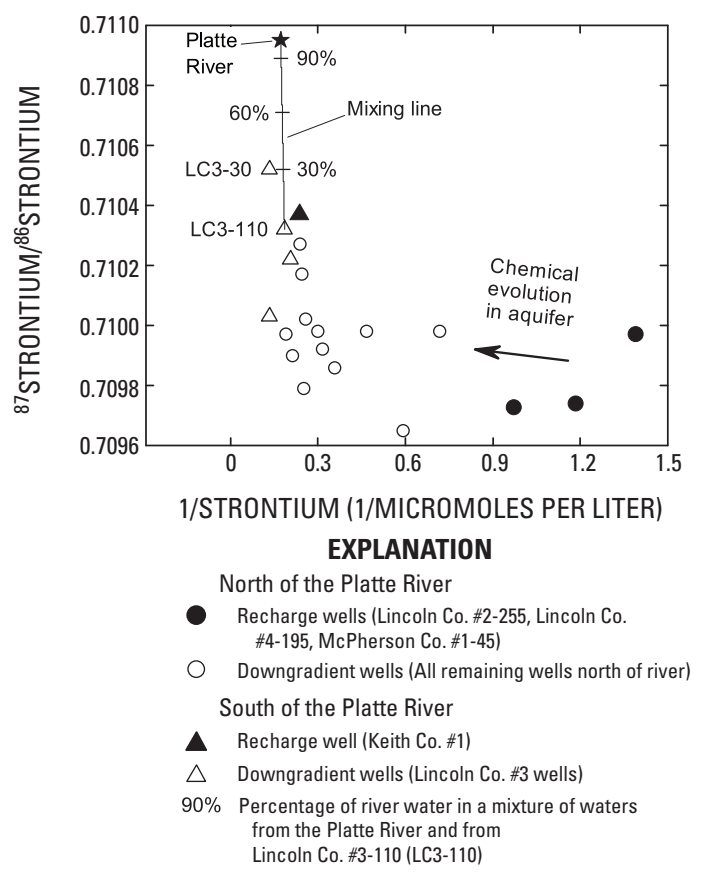

Figure 11. Strontium isotope ratios in relation to inverse strontium concentrations for water from the water-table and nested wells. 
2000), in the aquifer. The water sample from McPherson Co. \#1-550 was the only one to have a smaller $\mathrm{SO}_{4}{ }^{2-}$ concentration ( about $0.1 \mathrm{mg} / \mathrm{L}$ ) and larger $\delta^{34} \mathrm{~S}$ value $(3.94 \%$ ) than the recharge waters (fig. 12). The decrease in concentration and increase in $\delta^{34} \mathrm{~S}$ value probably is the result of microbial $\mathrm{SO}_{4}{ }^{2-}$ reduction, which could occur in the absence of dissolved $\mathrm{O}_{2}$ and $\mathrm{NO}_{3}^{-}$in ground water, which was the case at that well (Appendix 1). Sulfate reduction produces hydrogen sulfide $\left(\mathrm{H}_{2} \mathrm{~S}\right)$, but none was detected in the sample from McPherson Co. \#1-550. The produced $\mathrm{H}_{2} \mathrm{~S}$ may have reacted with dissolved iron $\left(\mathrm{Fe}^{2+}\right)$ or manganese $\left(\mathrm{Mn}^{2+}\right)$ and precipitated from solution. Water from McPherson Co. \#1-550 did contain a relatively elevated $\mathrm{Mn}^{2+}$ concentration (Appendix 1).

Precipitation is the ultimate source of water in the aquifer and evaporation of that precipitation could increase the concentration of dissolved constituents in recharge. Chloride and bromide $(\mathrm{Br})$ concentrations are expected to be conservative in the aquifer; therefore, they could be useful indicators of

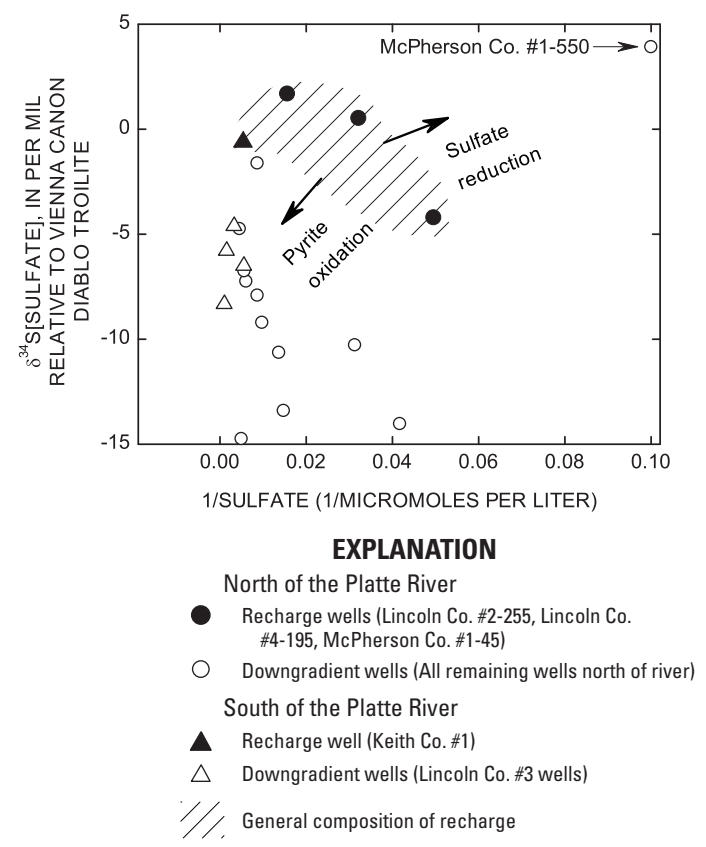

Figure 12. Sulfur isotope ratios in relation to inverse sulfate concentrations for water from the water-table and nested wells.

evaporation during recharge. Concentrations of $\mathrm{Cl}^{-}$and $\mathrm{Br}^{-}$in ground water generally plotted along a trend line originating near the mean concentration of precipitation at North Platte (fig. 13), indicating that evaporation may have influenced the concentration of dissolved constituents in recharge or shallow ground water. Evaporation effects, if they occurred, did not have a large effect on the $\delta^{2} \mathrm{H}\left[\mathrm{H}_{2} \mathrm{O}\right]$ and $\delta^{18} \mathrm{O}\left[\mathrm{H}_{2} \mathrm{O}\right]$ compositions for ground water (table 4), which plotted along the meteoric water line developed for North Platte, Nebraska, by Harvey and Welker (2000). The mean $\mathrm{Cl}^{-}$concentration in North Platte precipitation was calculated from the analyses of wet deposition collected near North Platte from 1984 to 2004 (National Atmospheric Deposition Program, 2005). Bromide was not measured in the precipitation, so $\mathrm{Br}$ concentrations in precipitation were calculated on the basis of the mean $\mathrm{Cl}^{-}$concentration in precipitation and the mean $\mathrm{Br} / \mathrm{Cl}$ ratio (.00642) in water from Lincoln Co. \#2, Lincoln Co. \#4, and McPherson Co. \#1. Those water-table wells contained the smallest $\mathrm{Cl}^{-}$concentrations and are considered to be the closest to precipitation in composition. This approach for estimating the $\mathrm{Br}$ concentration in precipitation assumes that the $\mathrm{Br} / \mathrm{Cl}$ ratio in ground water near the water table is representative of the ratio in precipitation.

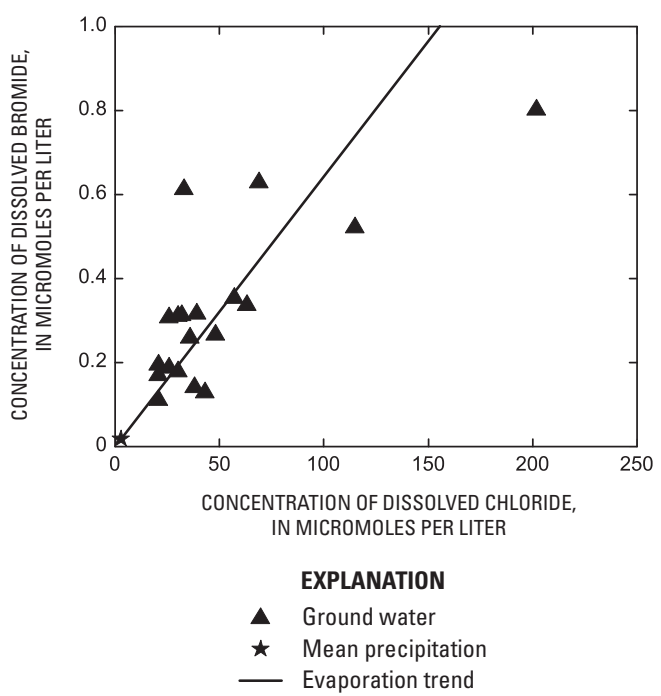

Figure 13. Concentrations of dissolved bromide in relation to concentrations of dissolved chloride in water from the nested wells and in precipitation. Precipitation data for chloride from North Platte, Nebraska (National Atmospheric Deposition Program, 2005). The precipitation value of bromide/chloride was assumed to be equal to that in water from the shallow wells at Lincoln Co. \#2, Lincoln Co. \#4, and McPherson Co. \#1.

For the most part, trace element concentrations were small and did not exhibit any systematic changes with depth below the water table (Appendix 1). None of the trace elements exceeded a Federal primary drinking-water standard, although the secondary drinking-water standard for manganese $(50 \mu \mathrm{g} / \mathrm{L})$ was exceeded in water from three wells (Lincoln Co. \#1-25, Lincoln Co. \#1-119, and McPherson Co. \#1-550) (U.S. Environmental Protection Agency, 2006). The elevated $\mathrm{Mn}^{2+}$ concentrations in those wells probably resulted from microbial 
$\mathrm{Mn}(\mathrm{IV})$ reduction associated with anoxic conditions in those waters. The two largest arsenic (As) concentrations, 9.2 and $9.8 \mu \mathrm{g} / \mathrm{L}$, occurred in oxygenated water from water-table wells Lincoln Co. \#2-255 and Lincoln Co. \#4-195 (Appendix 1). The Federal primary drinking-water standard for As is $10 \mu \mathrm{g} / \mathrm{L}$ (U.S. Environmental Protection Agency, 2006). Two common sources of As in ground water are the oxidation of sulfide minerals, such as pyrite, and the reductive dissolution of $\mathrm{Mn}$ and Fe oxides (Smedley and Kinniburgh, 2002). The fact that the two largest As concentrations occurred in oxygenated ground water indicates that oxidation of sulfide minerals could be an important mechanism for mobilizing As in the aquifer. This hypothesis is consistent with the interpretation that increases in concentrations of dissolved $\mathrm{SO}_{4}{ }^{2-}$ in the aquifer were the result of sulfide-mineral oxidation (fig. 12).

Radon concentrations generally exhibited increased concentrations with depth at the Lincoln Co. \#1, \#3, and \#4 nested well sites (Appendix 1). Concentrations at the base of the aquifer at each of those sites exceeded $300 \mathrm{pCi} / \mathrm{L}$, which is one option in the USEPA's proposed drinking-water standard for radon (U.S. Environmental Protection Agency, 1999). Overall, radon concentrations exceeded the proposed standard in water samples from 9 of the 19 nested wells.

\section{Nitrate}

Nitrogen $(\mathrm{N})$ is naturally present in relatively small concentrations in rocks, soils, organic material, and the water that comes in contact with them (Holloway and Dahlgren, 1999). Nitrogen also is present in relatively large concentrations in animal manure and fertilizers applied to agricultural fields and in sewage effluent. Nitrate, the most commonly occurring form of $\mathrm{N}$ in ground water, is of environmental concern because its discharge to surface water can support eutrophication. Nitrate also is a health concern because ingestion of large concentrations of $\mathrm{NO}_{3}^{-}$in drinking water can lead to low oxygen levels in the blood of infants (Fan and Steinberg, 1996). The USEPA has established a primary drinking-water standard for $\mathrm{NO}_{3}{ }^{-}$of $10 \mathrm{mg} / \mathrm{L}$ as N (U.S. Environmental Protection Agency, 2006).

Nitrite plus nitrate concentrations at the water table were 0.13 to 3.13 milligrams per liter as nitrogen, and concentrations substantially decreased with depth in the aquifer (Appendix 1). In all cases, $\mathrm{NO}_{3}{ }^{-}$concentrations were larger than $\mathrm{NO}_{2}^{-}$concentrations (median $\mathrm{NO}_{2}^{-} / \mathrm{NO}_{2}^{-}+\mathrm{NO}_{3}^{-}$ratio is $0)$. The relatively large $\mathrm{NO}_{3}{ }^{-}$concentration and postbomb ${ }^{3} \mathrm{H}$ concentration in water from Lincoln Co. \#3-30 indicates that recent recharge affected by agricultural activity was present near the water table at that site. Land use at the other nestedwell sites was undeveloped rangeland; therefore, $\mathrm{NO}_{3}{ }^{-}$concentrations near the water table at those sites may by representative of natural recharge. The smaller concentrations of $\mathrm{NO}_{3}^{-}$in water farther below the water table might be attributed to either a lack of $\mathrm{NO}_{3}^{-}$in recharge to those wells ( ${ }^{3} \mathrm{H}$ data indicate those waters were recharged prior to the start of modern agriculture in the area) or to denitrification along flow paths in the aquifer. Knowledge about denitrification in the aquifer is important because this process is the primary natural-attenuation mechanism for $\mathrm{NO}_{3}^{-}$contamination in ground water.

Denitrification is a microbially mediated process that reduces $\mathrm{NO}_{3}^{-}$to $\mathrm{N}_{2}$ gas in suboxic environments (eq. 8).

$$
\begin{array}{r}
4 \mathrm{NO}_{3}^{-}+5 \mathrm{C}+3 \mathrm{H}_{2} \mathrm{O}= \\
2 \mathrm{~N}_{2}+5 \mathrm{HCO}_{3}^{-}+\mathrm{H}^{+}
\end{array}
$$

In equation 8 , reduction of $\mathrm{NO}_{3}^{-}$is coupled to the oxidation of organic carbon, which produces $\mathrm{N}_{2}$ and bicarbonate. In some environments, denitrification may be coupled to the oxidation of sulfide minerals instead of, or in addition to, organic carbon (Postma and others, 1991; Böhlke and others, 2002), which produces $\mathrm{N}_{2}$ and dissolved $\mathrm{SO}_{4}{ }^{2-}$ (eq. 9).

$$
\begin{gathered}
6 \mathrm{NO}_{3}^{-}+2 \mathrm{FeS}_{2}+2 \mathrm{H}_{2} \mathrm{O}=3 \mathrm{~N}_{2}+ \\
2 \mathrm{FeOOH}+4 \mathrm{SO}_{4}{ }^{2^{-}}+2 \mathrm{H}^{+}
\end{gathered}
$$

One way to evaluate whether denitrification has occurred in the aquifer is to compare the $\delta^{15} \mathrm{~N}$ and $\delta^{18} \mathrm{O}$ values for $\mathrm{NO}_{3}^{-}$ in downgradient waters to the values for $\mathrm{NO}_{3}^{-}$in more recent recharge. This approach assumes steady-state conditions with respect to the isotopic composition of $\mathrm{NO}_{3}^{-}$in recharge, which may not be valid for ground water that spans a broad range of ages. Denitrification fractionates $\mathrm{N}$ and $\mathrm{O}$ isotopes such that the $\delta^{15} \mathrm{~N}$ and $\delta^{18} \mathrm{O}$ values for residual $\mathrm{NO}_{3}^{-}$become progressively larger as the reaction proceeds. The isotopic values for $\mathrm{NO}_{3}^{-}$that has been reduced should plot along trend lines with slopes of 1:2 to 1:1 (Böttcher and others, 1990; Granger and others, 2004) (fig. 14A). The data in fig. 14A roughly plot within these trend lines given the indicated isotopic compositions of $\mathrm{NO}_{3}^{-}$in recharge, indicating that denitrification probably has removed $\mathrm{NO}_{3}^{-}$from solution in the aquifer. This interpretation is consistent with the small concentrations of dissolved $\mathrm{O}_{2}$ in the aquifer. The modest fit of the isotopic data to the fractionation trend lines indicates that the isotopic composition of $\mathrm{NO}_{3}^{-}$in recharge may have been more variable than indicated in fig. 14A.

Another way to evaluate whether denitrification has occurred in the aquifer is to calculate the amount of $\mathrm{N}_{2}$ in ground water from denitrification, referred to here as "excess $\mathrm{N}_{2}{ }^{\prime \prime}$ (eq. 10).

$$
\begin{aligned}
& \text { excess } \mathrm{N}_{2}=\left[\mathrm{N}_{2} \text {-total }\right]-\left[\mathrm{N}_{2} \text {-air saturation }\right] \\
& -\left[\mathrm{N}_{2} \text {-excess air }\right]
\end{aligned}
$$

This approach has the added benefit of providing information on denitrification reaction progress. In equation 10 , $\mathrm{N}_{2}$-total represents the measured concentration of $\mathrm{N}_{2}$ dissolved in water (table 5), $\mathrm{N}_{2}$-air saturation represents the amount of $\mathrm{N}_{2}$ dissolved in water as a result of air-water equilibration at recharge conditions, and $\mathrm{N}_{2}$-excess air represents the amount of $\mathrm{N}_{2}$ in water from dissolution of excess air (air bubbles) in water.

The value of $\mathrm{N}_{2}$-air saturation is dependent on water temperature and elevation of the water table in the recharge area at the time of recharge. The latter factor is referred to as 

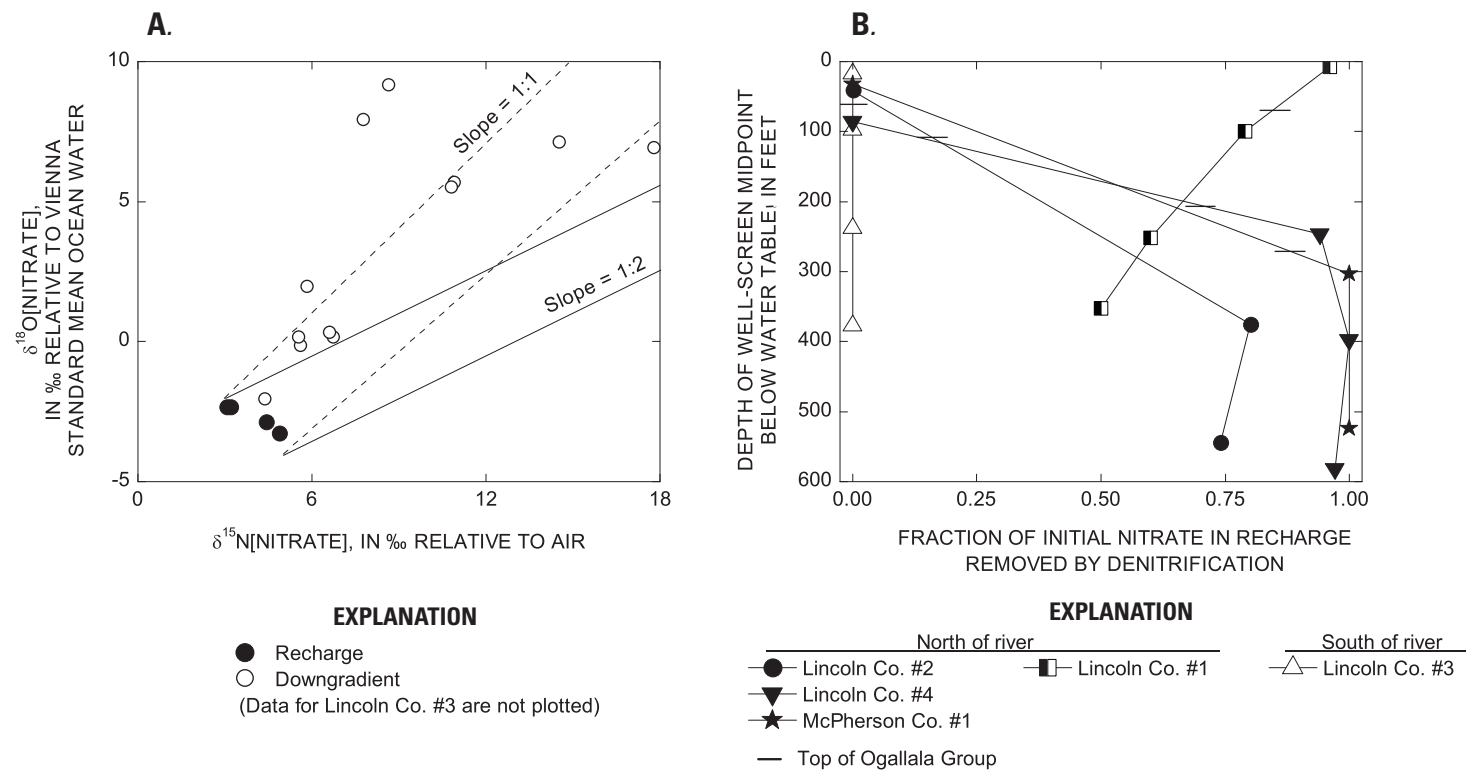

Figure 14. (A) Oxygen isotope values for nitrate in relation to nitrogen isotope values for nitrate and (B) fraction of initial nitrate in recharge remaining in solution in relation to well-screen depth below the water table for water from the nested wells.

"recharge elevation." Recharge temperatures were calculated using measured concentrations of dissolved $\mathrm{Ne}$ and $\mathrm{Ar}$ (Stute and Schlosser, 1993) and assuming complete dissolution of excess air during recharge. Recharge elevation depends on several factors, including depth of the well screen below the water table, location of the well in the regional flow system, and recharge rate (Cook and Böhlke, 2000). Recharge elevation increases relative to the local water-table elevation as the depth of the well screen below the water table increases. At each well nest, the elevation of the local water table was assumed to be representative of the recharge elevation of the shallowest well. Recharge elevations were increased in increments of $200 \mathrm{ft}$, relative to the local water-table elevation, for successively deeper wells. This represents a $600-\mathrm{ft}$ increase in recharge elevations for each well nest, which is similar to the total measured gain in water-table elevations from Lincoln Co. \#1 to McPherson Co. \#1 of $700 \mathrm{ft}$ (fig. 6). The calculated amount of excess $\mathrm{N}_{2}$ was not particularly sensitive to uncertainties in recharge elevation. For example, an elevation uncertainty of $\pm 200 \mathrm{ft}$ only produced uncertainties of about $\pm 0.3^{\circ} \mathrm{C}$ and $\pm 1 \mu \mathrm{M}( \pm 0.028 \mathrm{mg} / \mathrm{L}$ as $\mathrm{N})$ in recharge temperatures and excess $\mathrm{N}_{2}$ concentrations. equation 11:

The value of $\mathrm{N}_{2}$-excess air was calculated using

$$
\left[\mathrm{N}_{2} \text {-excess air }\right]=\left[\mathrm{N}_{2} / \text { Ar }\right] \text {-air } \times\{[\text { Ar-total }]-
$$$$
\text { [Ar-air saturation]\} }
$$

where $\left[\mathrm{N}_{2} / \mathrm{Ar}\right]$-air is the ratio of $\mathrm{N}_{2}$ and $\mathrm{Ar}$ in air, Ar-total represents the measured concentrations of Ar dissolved in water (table 5), and Ar-air saturation represents the amount of Ar dissolved in water as a result of air-water equilibration, as determined from the $\mathrm{Ne}$ and Ar data. Equation 11 assumes that the gas composition of the dissolved air bubbles was identical to that of air.

Recharge temperatures calculated using the $\mathrm{Ne}$ and $\mathrm{Ar}$ data ranged from 5.6 to $12.4^{\circ} \mathrm{C}$ and were consistently warmer for water sampled near the water table than for water sampled near the base of the aquifer (table 5). The average difference in recharge temperature between the top and bottom of the aquifer was $4.2^{\circ} \mathrm{C}$. This difference in recharge temperature, in part, is due to the increase in recharge elevation with depth below the water table. The gradient in mean annual air temperature in relation to land-surface elevation for the Sand Hills is estimated to be about $-0.07^{\circ} \mathrm{C} / 100 \mathrm{ft}$ (High Plains Regional Climate Center, 2005). This temperature-elevation gradient and the 600-ft increase in recharge elevation from the top to the bottom of the aquifer could account for about $0.5^{\circ} \mathrm{C}$ of the temperature difference. The remaining temperature difference presumably is related to changes in climatic conditions during the recharge history of the aquifer.

The amount of excess $\mathrm{N}_{2}$ in each sample can be calculated once recharge temperature and excess air are determined. Concentrations of excess $\mathrm{N}_{2}$ ranged from less than 30 to $113 \mu \mathrm{M}$ (less than 0.8 to $3.2 \mathrm{mg} / \mathrm{L}$ as N) (table 5). Excess $\mathrm{N}_{2}$ 
Table 5. Dissolved-gas and related data, recharge temperatures, and estimates of initial nitrate concentration and isotope values in recharge.

[Multiple entries indicate replicate samples or measurements; $\mu \mathrm{M}$, micromoles per liter; <, less than; >, greater than; \%o, per mil; ${ }^{\circ} \mathrm{C}$, degrees Celsius; $\mathrm{cm}^{3} \mathrm{STP} / \mathrm{L}$, cubic centimeters per liter at standard temperature and pressure; \pm , plus or minus 1 standard deviation; --, no data]

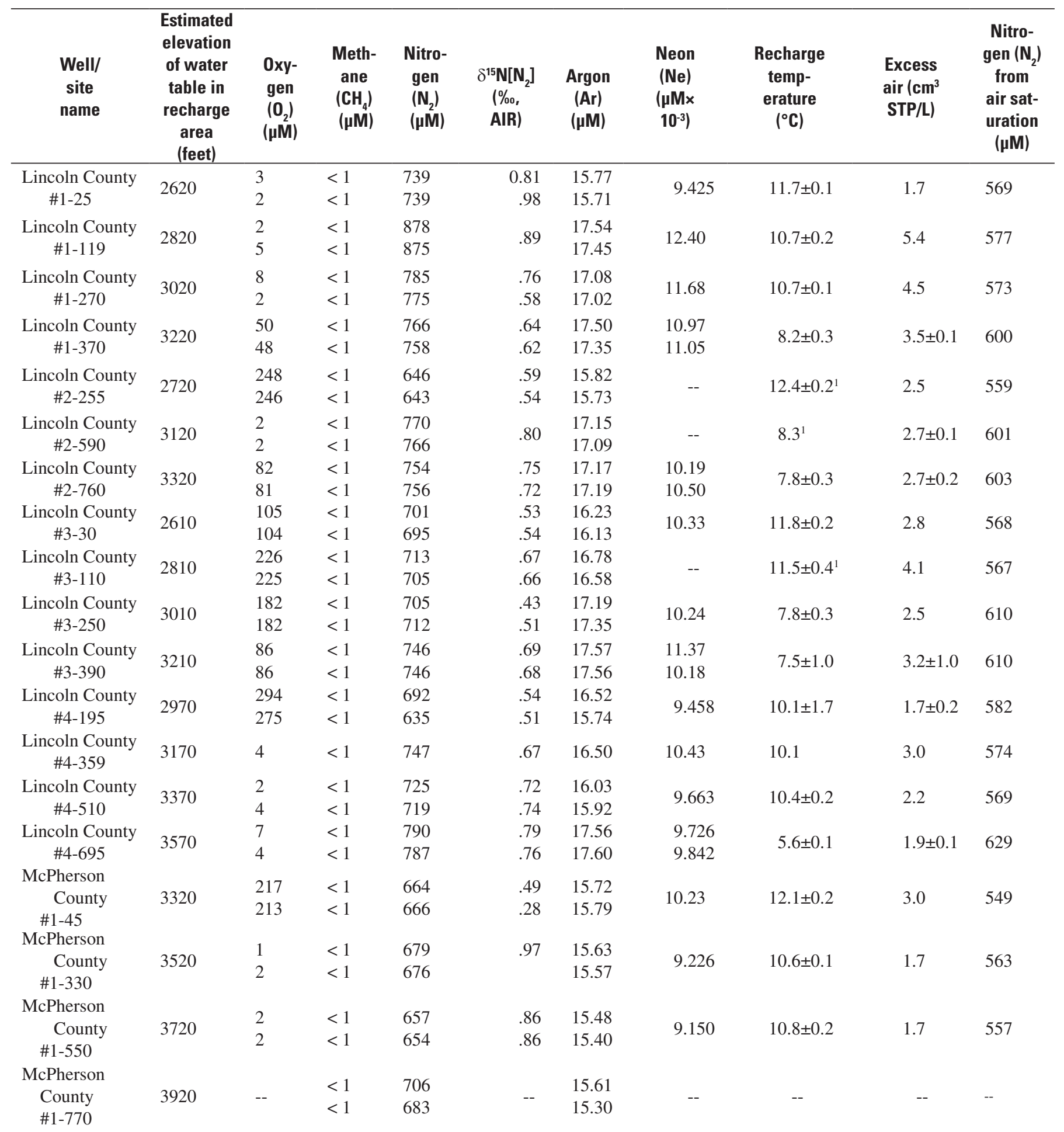


Table 5. Dissolved-gas and related data, recharge temperatures, and estimates of initial nitrate concentration and isotope values in recharge.-Continued

[Multiple entries indicate replicate samples or measurements; $\mu \mathrm{M}$, micromoles per liter; <, less than; >, greater than; \%o, per mil; ${ }^{\circ} \mathrm{C}$, degrees Celsius; $\mathrm{cm}^{3} \mathrm{STP} / \mathrm{L}$, cubic centimeters per liter at standard temperature and pressure; \pm , plus or minus 1 standard deviation; --, no data]

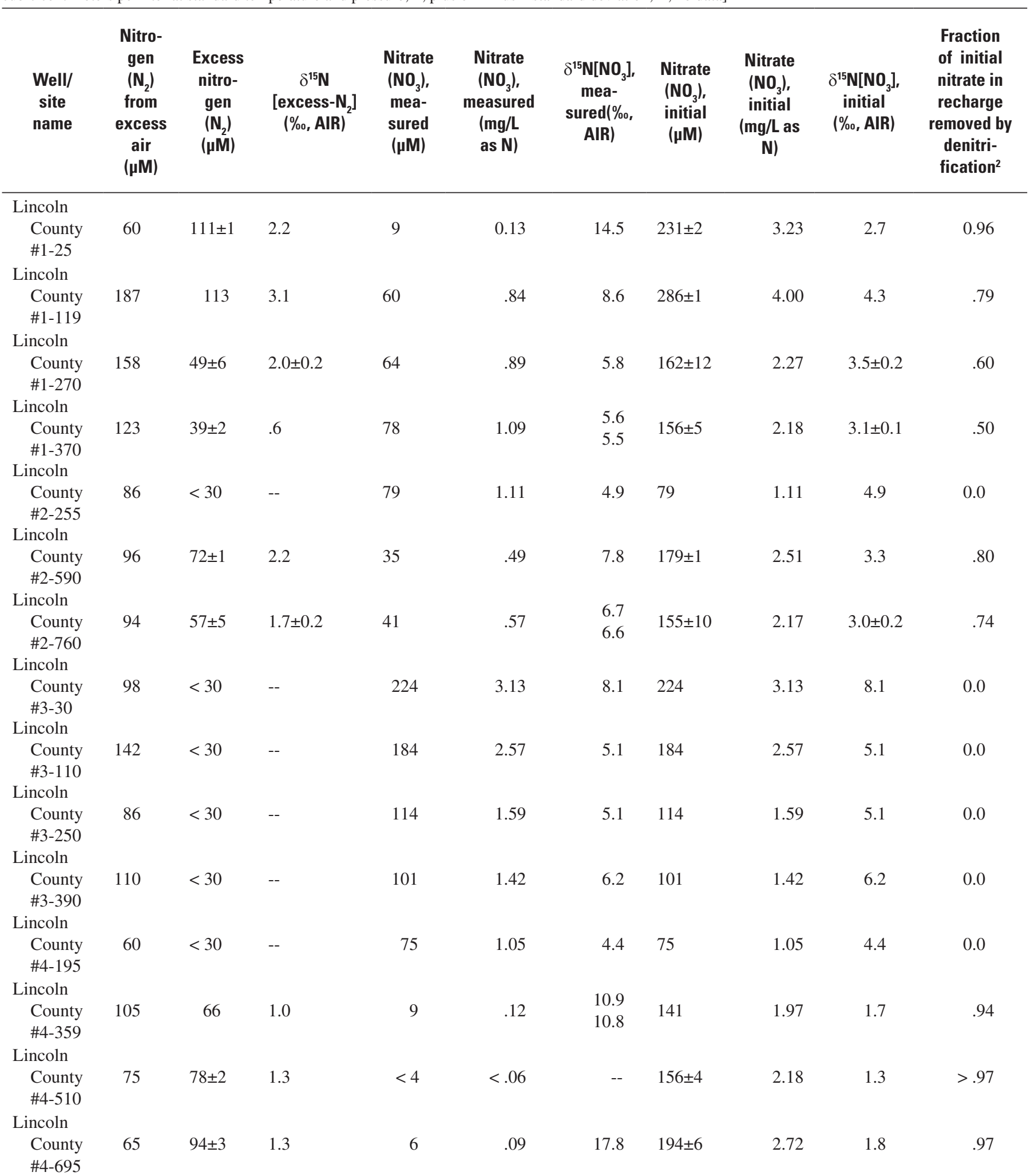


Table 5. Dissolved-gas and related data, recharge temperatures, and estimates of initial nitrate concentration and isotope values in recharge.-Continued

[Multiple entries indicate replicate samples or measurements; $\mu \mathrm{M}$, micromoles per liter; <, less than; >, greater than; \%o, per mil; ${ }^{\circ} \mathrm{C}$, degrees Celsius; $\mathrm{cm}^{3} \mathrm{STP} / \mathrm{L}$, cubic centimeters per liter at standard temperature and pressure; \pm , plus or minus 1 standard deviation; --, no data]

\begin{tabular}{|c|c|c|c|c|c|c|c|c|c|c|}
\hline $\begin{array}{c}\text { Well/ } \\
\text { site } \\
\text { name }\end{array}$ & $\begin{array}{l}\text { Nitrogen } \\
\left(\mathbf{N}_{2}\right) \text { from } \\
\text { excess } \\
\text { air }(\mu \mathrm{M})\end{array}$ & $\begin{array}{c}\text { Excess } \\
\text { nitro- } \\
\text { gen }\left(\mathbf{N}_{2}\right) \\
(\mu \mathrm{M})\end{array}$ & $\begin{array}{c}\delta^{15} \mathrm{~N} \\
{[\text { excess- }} \\
\left.\mathrm{N}_{2}\right] \\
(\% 0, \mathrm{AIR})\end{array}$ & $\begin{array}{c}\text { Nitrate } \\
\left(\mathrm{NO}_{3}\right), \\
\text { mea- } \\
\text { sured } \\
(\mu \mathrm{M})\end{array}$ & $\begin{array}{c}\text { Nitrate } \\
\left.\text { ( } \mathrm{NO}_{3}\right) \\
\text { mea- } \\
\text { sured } \\
\text { (mg/L } \\
\text { as } \mathrm{N} \text { ) }\end{array}$ & $\begin{array}{c}\delta^{15} \mathrm{~N}\left[\mathrm{NO}_{3}\right] \\
\text { mea- } \\
\text { sured(\% } \% \\
\text { AIR) }\end{array}$ & $\begin{array}{c}\text { Nitrate } \\
\left(\mathrm{NO}_{3}\right) \text {, } \\
\text { initial } \\
(\mu \mathrm{M})\end{array}$ & $\begin{array}{l}\text { Nitrate } \\
\left(\mathrm{NO}_{3}\right) \text {, } \\
\text { initial } \\
\text { (mg/L as } \\
\mathrm{N} \text { ) }\end{array}$ & $\begin{array}{c}\delta^{15} \mathrm{~N}\left[\mathrm{NO}_{3}\right] \\
\text { initial } \\
\text { (\%o, } \\
\text { AIR) }\end{array}$ & $\begin{array}{l}\text { Fraction } \\
\text { of initial nitrate } \\
\text { in recharge } \\
\text { removed by } \\
\text { denitrification }\end{array}$ \\
\hline $\begin{array}{c}\text { McPherson } \\
\text { County } \\
\# 1-45\end{array}$ & 105 & $<30$ & -- & 196 & 2.75 & $\begin{array}{l}3.2 \\
3.1\end{array}$ & 196 & 2.75 & $\begin{array}{l}3.2 \\
3.1\end{array}$ & 0.0 \\
\hline $\begin{array}{c}\text { McPherson } \\
\text { County } \\
\# 1-330\end{array}$ & 59 & $56 \pm 1$ & $4.2 \pm 0.1$ & $<4$ & $<.06$ & -- & $112 \pm 2$ & 1.57 & $4.2 \pm 0.1$ & $>.96$ \\
\hline $\begin{array}{c}\text { McPherson } \\
\text { County } \\
\# 1-550\end{array}$ & 59 & $40 \pm 1$ & $3.7 \pm 0.1$ & $<4$ & $<.06$ & -- & $80 \pm 1$ & 1.12 & $3.7 \pm 0.1$ & $>.95$ \\
\hline
\end{tabular}

${ }^{1}$ Recharge temperature estimated from nitrogen and argon data.

${ }^{2}$ Fraction removed by denitrification $=\left[1-\left(\right.\right.$ measured NO3-/initial $\left.\left.\mathrm{NO}^{-}\right)\right]$.

was present in all of the samples containing less than $16 \mu \mathrm{M}$ $(0.5 \mathrm{mg} / \mathrm{L})$ of $\mathrm{O}_{2}$ (table 5). Excess $\mathrm{N}_{2}$ was not detected in samples containing more than $62 \mu \mathrm{M}(2 \mathrm{mg} / \mathrm{L})$ of $\mathrm{O}_{2}$. The one exception was the sample from Lincoln Co. \#2-760, which contained $82 \mu \mathrm{M}(2.6 \mathrm{mg} / \mathrm{L})$ of $\mathrm{O}_{2}$ and $57 \mu \mathrm{M}$ of excess $\mathrm{N}_{2}$. As previously discussed, that sample may have contained a fraction of shallow ground water. The presence of excess $\mathrm{N}_{2}$ in ground water and its inverse correlation to $\mathrm{O}_{2}$ concentrations supports the interpretation that denitrification occurred in the aquifer.

Denitrification reaction progress is defined as the fraction, $f$, of initial $\mathrm{NO}_{3}^{-}$in recharge removed by denitrification (eq. 12).

$$
f=1-\frac{\left[\mathrm{NO}_{3}^{-}\right]_{\text {measured }}}{\left[\mathrm{NO}_{3}^{-}\right]_{\text {initial }}}
$$

where $\left[\mathrm{NO}_{3}^{-}\right]_{\text {measured }}$ is the measured $\mathrm{NO}_{3}^{-}$concentration in the water sample and $\left[\mathrm{NO}_{3}^{-}\right]_{\text {initial }}$ is the initial $\mathrm{NO}_{3}^{-}$concentration in recharge. The initial $\mathrm{NO}_{3}{ }^{-}$concentration in recharge (in molar units) was calculated using equation 13.

$$
\begin{aligned}
& {\left[\mathrm{NO}_{3}^{-}\right]_{\text {initial }}=\left[\mathrm{NO}_{3}^{-}\right]_{\text {measured }}} \\
& +2 \times\left[\text { excess } \mathrm{N}_{2}\right]
\end{aligned}
$$

Initial $\mathrm{NO}_{3}{ }^{-}$concentrations ranged from 75 to $286 \mu \mathrm{M}$ (1.05 to $4.00 \mathrm{mg} / \mathrm{L}$ as $\mathrm{N}$ ) (table 5). Denitrification removed
0 to more than 97 percent of the initial $\mathrm{NO}_{3}{ }^{-}$in recharge (average $=50$ percent) (fig. 14B), on the basis of the initial and measured $\mathrm{NO}_{3}{ }^{-}$concentrations. These results indicate that denitrification was an important process for attenuating $\mathrm{NO}_{3}{ }^{-}$concentrations in some parts of the aquifer.

Average denitrification reaction progress north of the river (66 percent) was substantially greater than it was for the single well nest south of the river (0 percent) (fig. 14B), and it appears to be related to the presence of thick deposits of sediment on top of the Ogallala Group north of the river (fig. $6)$. The importance of those sediments in terms of denitrification is evident from the changes in denitrification reaction progress with depth at Lincoln Co. \#4 and McPherson Co. \#1 (fig. 14B). Nearly all of the $\mathrm{NO}_{3}{ }^{-}$removal by denitrification at those sites occurred between the two shallowest wells, which are screened above or near the top of the Ogallala Group (fig. 14B). There was little additional $\mathrm{NO}_{3}{ }^{-}$removal in the Ogallala Group, which is similar to what was observed south of the river at Lincoln Co. \#3. The change in denitrification reaction progress with depth at Lincoln Co. \#1 was unique among the nested-well sites. Reaction progress at that site actually decreased with depth. That site is characterized by a shallow depth to water and soils composed of silt and fine sand. That combination of factors, and possibly others, apparently supported substantial denitrification near the water table. The decrease in reaction progress below the shallow well may be related to the convergence of flow paths from multiple depths in the regional discharge area of the river valley. In gen- 
eral, the sediments on top of the Ogallala Group in the Sand Hills provide the aquifer a level of protection from $\mathrm{NO}_{3}{ }_{3}^{-}$contamination that is not present south of the river.

Measured concentrations and isotopic values for $\mathrm{NO}_{3}{ }_{3}^{-}$ and $\mathrm{N}_{2}$ were used to reconstruct the $\mathrm{N}$ isotopic composition of initial $\mathrm{NO}_{3}^{-}$in recharge. The initial values ranged from 1.3 to $4.9 \%$ (average $=3.2 \%$ ) for wells north of the river (table 5). These are relatively small $\delta^{15} \mathrm{~N}$ values for $\mathrm{NO}_{3}{ }^{-}$that presumably was derived from soil N (Kreitler, 1979; Heaton, 1986). Interestingly, the $\delta^{15} \mathrm{~N}$ values for natural $\mathrm{NO}_{3}^{-}$in ground water systematically increase from the northern High Plains to the southern High Plains (McMahon and Böhlke, 2006). McMahon and Böhlke (2006) discuss possible mechanisms to explain this observation. It is important to understand the variability in $\delta^{15} \mathrm{~N}$ values for natural $\mathrm{NO}_{3}^{-}$if isotopes are to be used as a tracer of $\mathrm{NO}_{3}^{-}$contamination in semiarid regions such as the High Plains. This is because large natural $\mathrm{NO}_{3}^{-}$deposits in the subsoil, which are known to exist in the High Plains (Boyce and others, 1976; McMahon and others, 2006), can be mobilized by irrigation return flow. Differentiating between agricultural and natural $\mathrm{NO}_{3}^{-}$in return flow on the basis of $\mathrm{N}$ isotopes can be complicated if there is large variability in the $\delta^{15} \mathrm{~N}$ values of natural $\mathrm{NO}_{3}{ }^{-}$.

\section{Pesticides}

The water-table well at Lincoln Co. \#3 was the only one to produce water that contained a detection of a pesticide compound. Deethylatrazine was detected in water from that well at an estimated concentration of $0.006 \mu \mathrm{g} / \mathrm{L}$ (Appendix 1). Deethylatrazine is a degradation product of atrazine, a common corn herbicide, and corn is grown in that area.

\section{Vertical Gradients in Ground-Water Age}

As discussed in the "Tritium" section, water from some of the water-table wells was recharged after the early 1950s, whereas water from the deeper wells at most sites was recharged before the early 1950s. These data indicate vertical gradients in ground-water age were present at those sites. The magnitude of the gradient, however, cannot be determined using ${ }^{3} \mathrm{H}$ data alone. Measurements of ${ }^{14} \mathrm{C}[\mathrm{DIC}]$ have been used by several researchers to estimate ground-water ages greater than about 1,000 years. Applying ${ }^{14} \mathrm{C}[\mathrm{DIC}]$ measurements to ground-water age-dating issues requires that those measurements be adjusted for the addition or removal of DIC along flow paths leading to the sampled wells. Construction of mass-balance models to account for changes in concentrations of dissolved constituents between initial and final waters along flow paths is one approach for making those adjustments (Plummer and others, 1990; Aravena and others, 1995, Kalin, 2000; McMahon and others, 2004a).

\section{Mass-Balance Models}

Mass-balance models require chemical and isotopic data for initial (upgradient) and final (downgradient) waters. The initial and final waters are from wells assumed to be located on the same flow path, and it is further assumed that the chemistry of the initial water has not changed over time. In other words, the chemistry of the initial water should be representative of the chemistry of the final water at the time it was recharged. For radiocarbon dating purposes, the samples should be free of postbomb ${ }^{14} \mathrm{C}$. For the High Plains aquifer, water containing less than $0.5 \mathrm{TU}^{3} \mathrm{H}$ is assumed to be free of postbomb ${ }^{14} \mathrm{C}$. McMahon and others (2004a) constructed mass-balance models for the central High Plains aquifer by using samples from the most upgradient water-table wells in a regional transect as initial waters because simulations of ground-water movement indicated those areas were the most likely recharge areas to downgradient wells and because they contained less than $0.5 \mathrm{TU}^{3} \mathrm{H}$. A similar approach was used in this study.

Even with the steps taken to match final waters with appropriate initial waters, it is difficult to establish whether initial and final waters selected for mass-balance modeling actually were aligned along the same flow path. Thus, chemical analyses from the shallowest wells at Lincoln Co. \#2, Lincoln Co. \#4, and McPherson Co. \#1 were used to represent the composition of initial waters for nested wells located north of the river (table 4 and Appendix 1). In other words, each of the final waters was modeled using three different initial waters. The shallowest well at McPherson Co. \#1 was included in this group, even though the sample from that well contained 5.8 $\mathrm{TU}{ }^{3} \mathrm{H}$, because its ${ }^{14} \mathrm{C}[\mathrm{DIC}]$ composition was not enriched in ${ }^{14} \mathrm{C}$ compared to water that was recharged prior to the early 1950s (table 4). For nested wells located south of the river (Lincoln Co. \#3), the chemical analysis from Keith Co. \#1 was used to represent the composition of initial waters (fig. 2).

The computer code NETPATH (Plummer and others, 1994) was used to construct mass-balance models using the initial waters described above and final waters defined by the deeper wells in each well nest. The constraints used in the models were concentrations of aluminum (Al), Ca, DIC, Fe, $\mathrm{N}, \mathrm{Na}$, sulfur $(\mathrm{S})$, silicon $(\mathrm{Si})$, and redox state of the water. Additional constraints were imposed by using mineralogic data, mineral saturation indices, and isotopic data for dissolved species and solid phases containing $\mathrm{C}$. The following phases were included in the mass-balance models: calcite, lignite $\left(\mathrm{CH}_{2} \mathrm{O}\right), \mathrm{Ca}-\mathrm{Na}$ exchange, albite, sodium plagioclase $\left(\mathrm{Na}_{0.62} \mathrm{Ca}\right.$ ${ }_{0.38} \mathrm{Al}_{1.38} \mathrm{Si}_{2.62} \mathrm{O}_{8}$ ), kaolinite, $\mathrm{SiO}_{2}$, pyrite, goethite, $\mathrm{CO}_{2}$ gas, and $\mathrm{N}_{2}$ gas. Lignite and pyrite were included in the mass-balance models to provide a source of electrons for the reduction of dissolved $\mathrm{O}_{2}$ and $\mathrm{NO}_{3}^{-}$(eqs. 8 and 9). Pyrite also was a source of dissolved $\mathrm{S}$.

Several mass-balance models were identified for each pair of initial and final waters; however, constraints imposed by the saturation indices and isotopic data eliminated many of them. The mass-balance results listed in Appendix 2 
satisfied most of the constraints imposed by the data. Most of the models for wells north of the river required the dissolution of sodium plagioclase and calcite; the precipitation of kaolinite and $\mathrm{SiO}_{2}$; and cation exchange. All but one model required the coupling of lignite or pyrite oxidation to the reduction of $\mathrm{O}_{2}$ or $\mathrm{NO}_{3}^{-}$, thereby producing $\mathrm{CO}_{2}$ in the case of lignite oxidation. It was not possible to know the $\mathrm{O}_{2}$ concentration in the final water at the time of recharge; therefore, the amount of $\mathrm{O}_{2}$ reduction was calculated as the difference in $\mathrm{O}_{2}$ concentrations between the initial and final waters. The amount of denitrification was assumed to equal the amount of excess $\mathrm{N}_{2}-\mathrm{N}$ present in the final waters, as previously discussed (table 5). Thus, for calculating mass balances between initial and final waters, the $\mathrm{NO}_{3}^{-}$concentration in the initial water was set equal to the $\mathrm{NO}_{3}{ }^{-}$concentration in the final water at the time it was recharged (table 5). Models for wells south of the river (Lincoln Co. \#3) required calcite precipitation and little or no lignite oxidation. Calcite precipitation was required because of the relatively large DIC and $\mathrm{Ca}^{2+}$ concentrations in the initial water (Keith Co. \#1) relative to the final waters. Very little lignite oxidation was required because the final waters contained substantial amounts of $\mathrm{O}_{2}$ and no excess $\mathrm{N}_{2}$. It should be noted that the mass-balance models are considered to be nonunique because small variations in several of the model parameters could provide similar matches between measured and calculated values. However, none of the variations in model parameters that satisfied the model constraints produced substantially different results in the radiocarbon ages.

Very small additions of $\mathrm{CO}_{2}$ were required to achieve mass balance in a few models, even though the system below the water table is considered closed to exchange of $\mathrm{CO}_{2}$ gas with the soil atmosphere. Most of the models also required a small component of evaporation to achieve mass balance. The $\mathrm{Cl}^{-}$and $\mathrm{Br}$ data indicate that evaporation of precipitation or shallow ground water may have occurred (fig. 13), but the $\mathrm{CO}_{2}$ additions and evaporation also could reflect uncertainties in (a) selecting the appropriate initial water for the final waters, (b) the DIC analyses, and (c) the charge imbalance of the major-ion analyses (Plummer and others, 2004). Selected final waters also were modeled using the computer code PHREEQC (Parkhurst and Appelo, 1999) because it allows the user to assign uncertainties to the chemical and isotopic data for initial and final waters. Those models did not require $\mathrm{CO}_{2}$ additions and resulted in slightly larger radiocarbon ages than the ages calculated by using the NETPATH models, as will be discussed in the next section.

\section{Radiocarbon Ages}

Adjusted radiocarbon ages of ground water were calculated using NETPATH and the radioactive decay equation:

$$
\Delta t=\frac{5,730}{\ln 2} \ln \left(\frac{A_{n d}}{A}\right)
$$

where $\Delta \mathrm{t}$ (in years) is the time since ground water was isolated from the atmosphere, 5,730 is the half-life of ${ }^{14} \mathrm{C}$ (in years), $\mathrm{A}_{\text {nd }}$ (in pmc) is the ${ }^{14} \mathrm{C}[\mathrm{DIC}]$ value in the final water adjusted for $\mathrm{C}$ mass transfers in the absence of radioactive decay, and $\mathrm{A}$ (in pmc) is the measured value of ${ }^{14} \mathrm{C}[\mathrm{DIC}]$ in the final water. The value of $A_{n d}$ is dependent on the value of $A_{o}$ (the ${ }^{14} \mathrm{C}[\mathrm{DIC}]$ value in the initial water, table 4 ) and the $C$ mass transfers calculated in the mass-balance models (Appendix 2).

Values of ${ }^{14} \mathrm{C}[\mathrm{DIC}]$ from the shallowest wells at Lincoln Co. \#2, Lincoln Co. \#4, and McPherson Co. \#1 were used to represent $A_{o}$ values north of the river. Those ${ }^{14} \mathrm{C}[\mathrm{DIC}]$ values range from 73.4 to 91.6 pmc (table 4). Radiocarbon was not measured in water from Keith Co. \#1, the initial water south of the river; therefore, initial ${ }^{14} \mathrm{C}$ activity models available in NETPATH were used to estimate $\mathrm{A}_{\mathrm{o}}$ at that site (Plummer and others, 1994). The activity models presented by Fontes and Garnier (1979) and Plummer and others (1990) provided estimates of $\mathrm{A}_{\mathrm{o}}$ that ranged from 50 to $55 \mathrm{pmc}$. These values are similar to the measured $A_{0}$ values for recharge in the central and southern High Plains (McMahon and others, 2004a, b), but they are smaller than the values north of the river. This difference may be due to less carbonate-mineral dissolution by water in the unsaturated zone as it moved from the land surface to the water table north of the river compared to south of the river. Dissolution of ${ }^{14} \mathrm{C}$-free carbonate minerals in the unsaturated zone would decrease $\mathrm{A}_{\mathrm{o}}$ values. This interpretation is consistent with the larger calcite saturation index at Keith Co. \#1 (-0.15) compared to the average saturation index for the three initial waters north of the river (-1.14), indicating that recharge south of the river was near equilibrium with respect to calcite but recharge north of the river was undersaturated with respect to calcite.

Unadjusted and adjusted radiocarbon ages calculated using these $A_{0}$ values are listed in table 6 . The radiocarbon ages presented here do not account for the possibility that ${ }^{14} \mathrm{C}[\mathrm{DIC}]$ of recharge varied over time because of variations in the Earth's geomagnetic field strength and solar fluctuations (Mazaud and others, 1991; Bard and others, 1993). Age corrections for matrix diffusion (molecular diffusion of ${ }^{14} \mathrm{C}$ [DIC] from sand to clay layers) were not made in this study but could produce younger adjusted ages than those reported in table 6 (Bethke and Johnson, 2002). Average adjusted radiocarbon ages from NETPATH ranged from 1,800 to 15,600 years, and they were from 0 to 4,300 years younger than the unadjusted ages. On average, radiocarbon ages calculated using mass transfers from PHREEQC were 900 years older than the ages calculated using mass transfers from NETPATH. This difference is similar to the 1-sigma precision of the age estimates from NETPATH (table 6).

Ground-water ages increased substantially with depth below the water table at all of the sites except McPherson Co. \#1 (fig. 15), indicating that the aquifer in most areas contained a stratified sequence of ground-water ages that was characterized by a relatively thin zone of recently recharged water (less than $50 \mathrm{yr}$, as indicated by ${ }^{3} \mathrm{H}$ concentrations larger than 0.5 TU) overlying a thicker zone of water that was recharged from 
Table 6. Summary of ground-water ages from tritium and radiocarbon dating.

[Multiple entries indicate replicate samples or measurements; TU, tritium units; pmc, percent modern carbon; <, less than; >, greater than; \pm , plus or minus 1 standard deviation; --, not applicable]

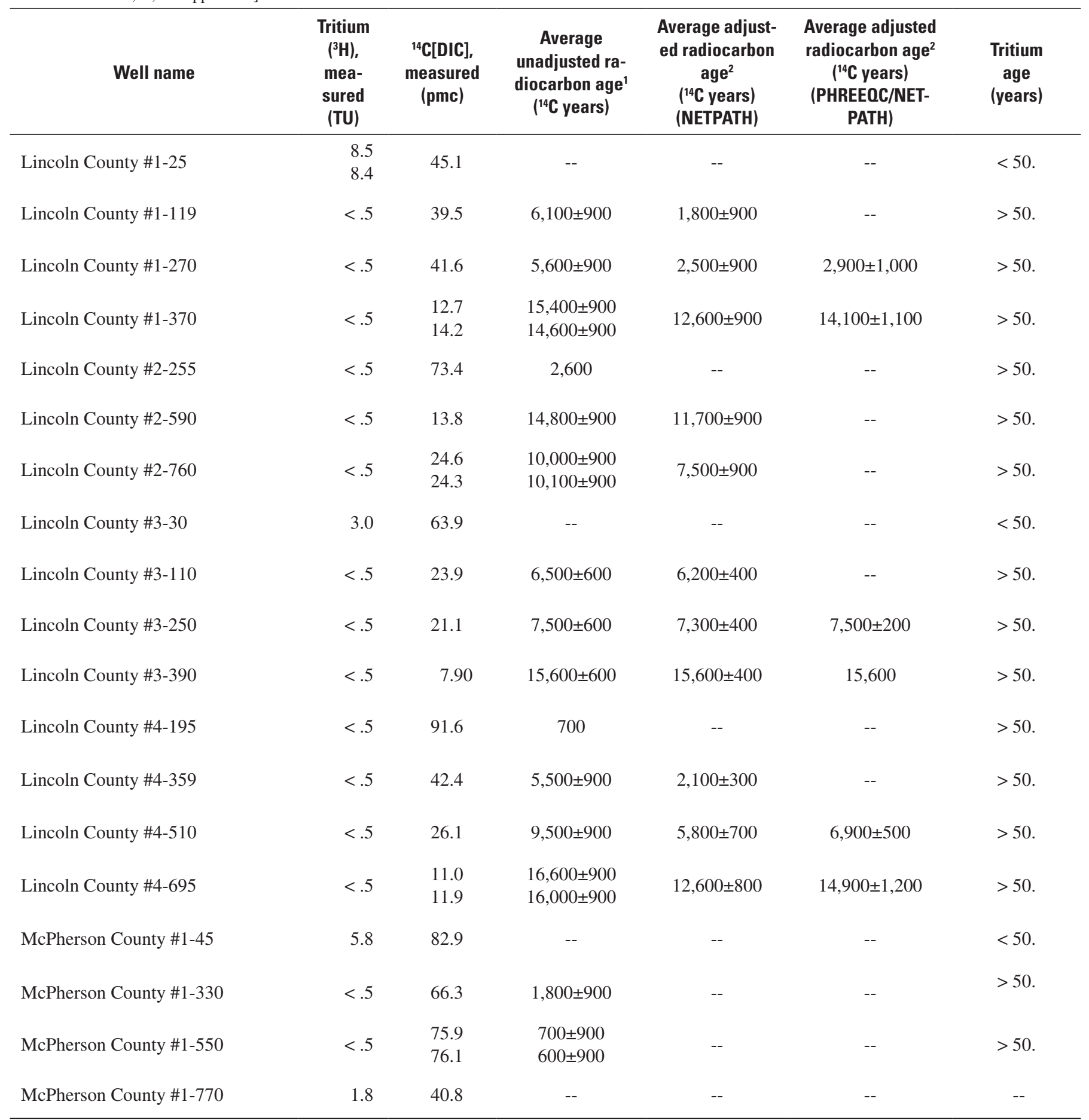

${ }^{1}$ Assumes initial ${ }^{14} \mathrm{C}$ values of $73.4,82.9$, and 91.6 pmc for wells north of the river and ${ }^{14} \mathrm{C}$ values of 50 and 55 pmc for wells south of the river (Lincoln Co. \#3), except for wells Lincoln Co. \#2-255 and Lincoln Co. \#4-195 which were assumed to have an initial ${ }^{14} \mathrm{C}$ value of 100 pmc. Does not account for addition or removal of carbon along flow paths.

${ }^{2}$ Assumes initial ${ }^{14} \mathrm{C}$ values of $73.4,82.9$, and 91.6 pmc for wells north of the river and ${ }^{14} \mathrm{C}$ values of 50 and 55 pmc for wells south of the river (Lincoln Co. \#3). Accounts for addition and removal of carbon along flow paths. 
about 1,800 to $15,600{ }^{14} \mathrm{C}$ years ago. No recently recharged water was detected at the two sites (Lincoln Co. \#2 and \#4) with unsaturated zones thicker than $100 \mathrm{ft}$ (table 4). At Lincoln Co. \#1 and \#3, the aquifer contained, at most, 24 to 26 percent recently recharged water on the basis of screen depths below the water table and saturated thicknesses and assum-

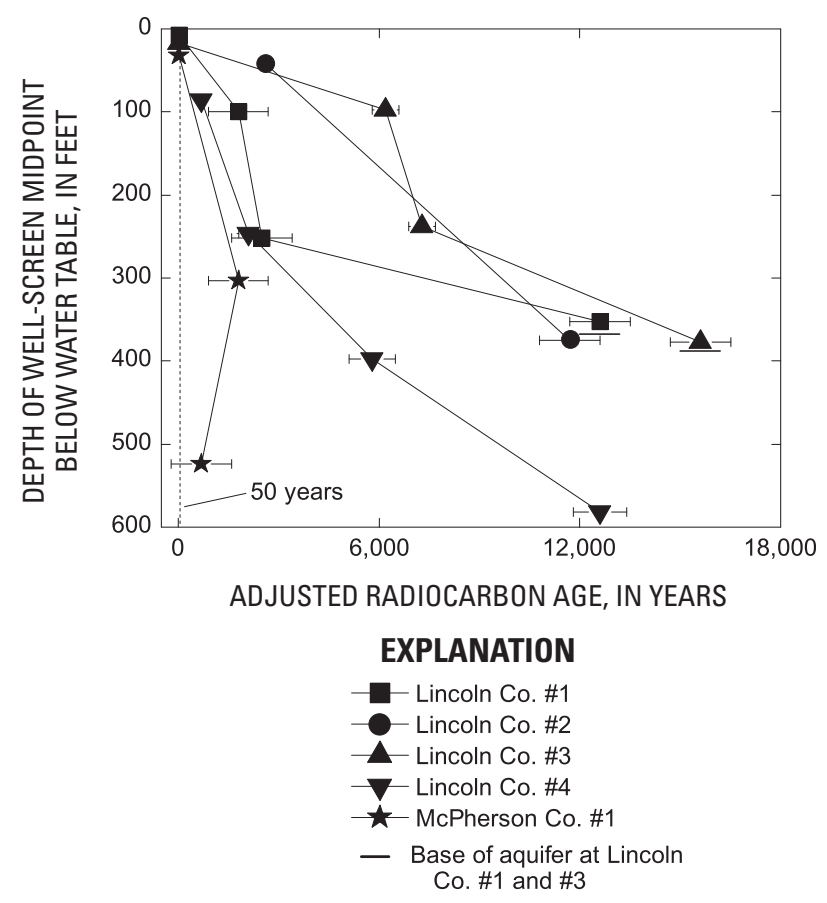

Figure 15. Adjusted radiocarbon age in relation to depth below the water table. Lincoln Co.\#1-25, Lincoln Co. \#3-30, and McPherson Co. \#1-45 were assigned ages of 25 years on the basis of tritium data, which indicate ages less than 50 years (table 6). Unadjusted radiocarbon ages were assigned to Lincoln Co. \#2-255, Lincoln Co. \#4-195, and the two deeper wells at McPherson Co. \#1 (table 6).

ing that only recent recharge was present in the aquifer above the shallowest well with ${ }^{3} \mathrm{H}$ concentrations less than $0.5 \mathrm{TU}$ (fig. 16). The actual percentages are not well defined because of the large vertical spacing between wells, but they could be smaller than these. These results have important implications with respect to development of ground-water resources in the Sand Hills. Most of the water in the aquifer predates modern anthropogenic activity so excessive removal of water by pumping is not likely to be replenished by natural recharge in a meaningful timeframe. Excessive ground-water pumping generally has not occurred in the Sand Hills, but it has resulted in large water-level declines in parts of the aquifer south of the river (fig. 4) (McGuire and Sharpe, 1997).

The decrease in ground-water age near the base of the aquifer at Lincoln Co. \#2 (Lincoln Co. \#2-760, table 6) most likely is the result of mixing with shallow (young) ground water during or after well construction and is not considered to be representative of natural conditions in the aquifer. Mixing with shallow ground water also appears to have occurred in McPherson Co. \#1-770. Consequently, ages for water from those wells were not plotted in fig. 15 .

Vertical gradients in age were calculated using equation 15:

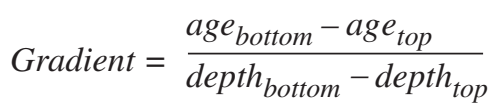

where $a g e_{\text {bottom }}$ refers to the radiocarbon age (NETPATH) for the deepest wells in fig. 15, and age $e_{\text {top }}$ refers to the age for the shallowest wells. Depth bottom $_{\text {and }}$ depth $h_{\text {top }}$ refer to the well-screen depths below the water table for those wells. Age gradients ranged from 24 to $42 \mathrm{yr} / \mathrm{ft}$ at all the sites except McPherson Co. \#1. The age gradient at McPherson Co. \#1 was $1.3 \mathrm{yr} / \mathrm{ft}$, which is much smaller than the gradients observed at the other sites (fig. 15). The small gradient at McPherson Co. \#1 could be indicative of relatively rapid recharge that might be related to the large downward head gradient at that site (fig. 8). The age gradient at McPherson Co. \#1 corresponds to a recharge rate of about $0.2 \mathrm{ft} / \mathrm{yr}$, assuming a sediment porosity of 0.3 and a linear age gradient. The assumption of a linear age gradient may not be valid for McPherson Co. \#1, but it is difficult to determine on the basis of the existing data and their associated precisions. Nevertheless, this is the same recharge rate that was calculated for sandy soils at the Imperial site (fig. 2) on the basis of a tritium profile in the unsaturated zone (McMahon and others, 2006), and it is only about 20 percent larger than the largest recharge rate estimated for the Sand Hills on the basis of a regional ground-water flow model (Luckey and others, 1986). It is worth noting that ${ }^{14} \mathrm{C}$ samples were collected again at McPherson Co. \#1-330 and -550 about 8 months after the initial samples were collected to verify those earlier results. Both sample sets had very similar ${ }^{14} \mathrm{C}$ concentrations (table 4$)$.

Age gradients at Lincoln Co. \#1 and 4 (and possibly \#3) did not appear to be linear, so long-term average recharge rates at those sites were calculated using equation 16 :

$$
R=\frac{Z n}{a g e} \ln \left(\frac{Z}{Z-z}\right)
$$

where $R$ is recharge rate (ft/yr), $Z$ is aquifer thickness (ft), $z$ is depth below the water table (ft), $n$ is porosity (assumed to equal 0.3), and age is ground-water age at depth $z$ (yr). This approach assumes that the age-depth profiles follow an exponential age distribution (Cook and Böhlke, 2000). The exponential model appears to match the Lincoln Co \#1 and \#4 data reasonably well (fig. 17), resulting in recharge rates of 0.03 and $0.05 \mathrm{ft} / \mathrm{yr}$, respectively. These values are about 2 to 6 times smaller than the recharge rates estimated for the Sand Hills on the basis of a regional ground-water flow model (Luckey and others, 1986). The exponential model match to data from Lincoln Co. \#3 was less satisfactory, possibly as a result of pumping in the valley (fig. 4), which could vertically mix water in the aquifer. Nevertheless, the inferred recharge rate at that site $(0.02 \mathrm{ft} / \mathrm{yr})$ is similar to those at Lincoln Co. \#1 and $\# 4$. On average, recharge rates derived from age gradients in 


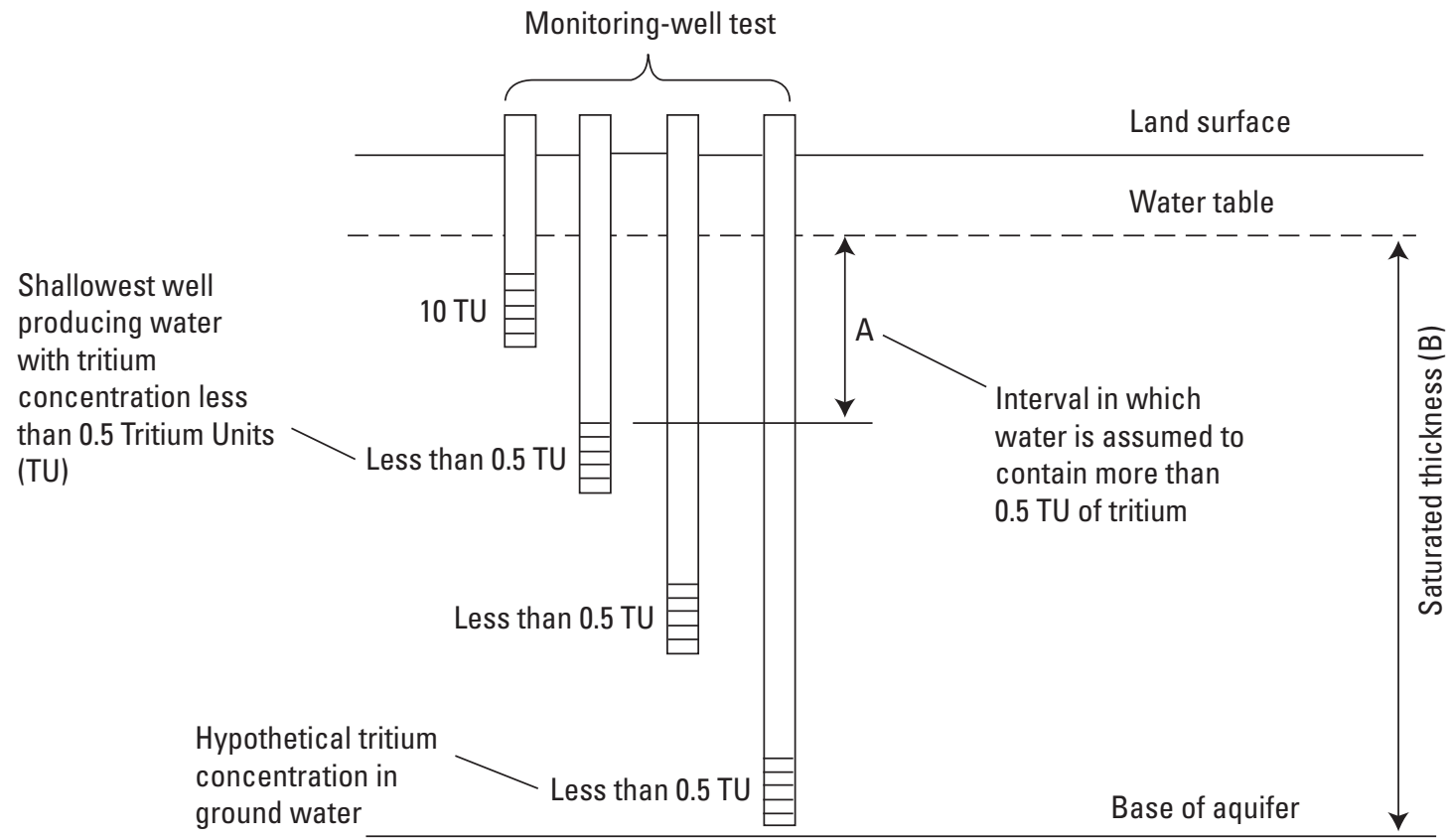

Percentage of saturated thickness containing recently recharged water $($ greater than $0.5 \mathrm{TU}$ of tritium $)=(\mathrm{A} / \mathrm{B}) \times 100$

Figure 16. Schematic diagram illustrating a method for calculating the maximum percentage of saturated thickness containing recently recharged water.

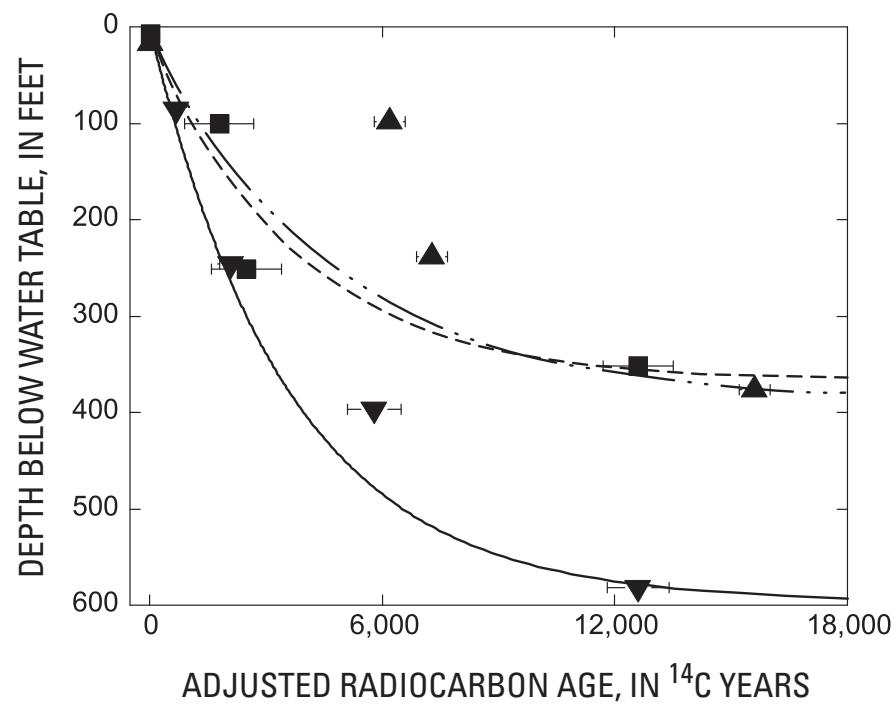

EXPLANATION

$\begin{array}{lccc}\text { Site } & \text { Model } & \text { Measured } & \text { Recharge Rate (ft/yr) } \\ \text { Lincoln Co. \#1 } & ---- & \square & 0.03 \\ \text { Lincoln Co. \#3 } & -\cdots & \mathbf{A} & 0.02 \\ \text { Lincoln Co. \#4 } & - & \boldsymbol{\nabla} & 0.05\end{array}$

Figure 17. Measured and modeled age distributions used to estimate long-term average recharge rates. 
the Sand Hills were about 8 times larger than those in the central High Plains aquifer (McMahon and others, 2004a). This apparent increase in recharge rates likely results from sandier soils (increased infiltration) and colder recharge temperatures (reduced evapotranspiration) in the Sand Hills compared to the central High Plains because mean annual precipitation in both study areas were within 5 percent of each other (High Plains Regional Climate Center, 2005).

Apparent rates of $\mathrm{O}_{2}$ reduction and denitrification were estimated on the basis of decreases in $\mathrm{O}_{2}$ concentrations and increases in concentrations of excess $\mathrm{N}_{2}$ and ground-water ages along flow paths from the water table to deeper wells. Decreases in $\mathrm{O}_{2}$ concentrations with depth at the nested-well sites indicate that many of the samples had lost some $\mathrm{O}_{2}$ (Appendix 1). For $\mathrm{O}_{2}$, calculations of apparent reduction rates assume ground water was recharged with $7.4 \mathrm{mg} / \mathrm{L}$ of dissolved $\mathrm{O}_{2}$, which is the average $\mathrm{O}_{2}$ concentration in water from the shallowest wells at Lincoln Co. \#2 and \#4, McPherson Co. \#1, and Keith Co. \#1 (Appendix 1). Using Lincoln Co. \#4-359 as an example, the apparent $\mathrm{O}_{2}$ reduction rate would be at least $0.003 \mathrm{mg} / \mathrm{L} / \mathrm{yr}$ on the basis of its measured $\mathrm{O}_{2}$ concentration (less than $0.5 \mathrm{mg} / \mathrm{L})$ and radiocarbon age $(2,100$ years). Apparent $\mathrm{O}_{2}$ reduction rates are listed in table 7 . Increases in excess $\mathrm{N}_{2}$ concentrations with depth at the nested-well sites indicate that many of the samples also underwent some denitrification (table 5). Calculations of apparent denitrification rates assume denitrification began where the traveltime was equal to one-half the adjusted radiocarbon age of water from the second shallowest well in each nest. This approach was used because denitrification in aquifer sediments probably does not begin until $\mathrm{O}_{2}$ concentrations have been reduced to about $2 \mathrm{mg} / \mathrm{L}$ or less (McMahon and others, 2004a, b), which typically occurred between the shallowest and second shallowest wells. Using Lincoln Co. \#4-359 as an example again, the apparent denitrification rate would be about $0.002 \mathrm{mg} / \mathrm{L} / \mathrm{yr}$ as $\mathrm{N}$ on the basis of the calculated excess $\mathrm{N}_{2}$ concentration $(66 \mu \mathrm{mol} / \mathrm{L}$ or $1.85 \mathrm{mg} / \mathrm{L}$ as $\mathrm{N})$ and the radiocarbon age of the sample $(2,100$ years $)$ minus the age when denitrification is assumed to have begun (1,050 years). Apparent denitrification rates are listed in table 7.

Median rates of $\mathrm{O}_{2}$ reduction and denitrification south of the river (Lincoln Co. \#3) were $0.0002 \mathrm{mg} / \mathrm{L} / \mathrm{yr}$ and less than $0.0002 \mathrm{mg} / \mathrm{L} / \mathrm{yr}$ as $\mathrm{N}$, respectively (table 7 ). These rates are similar to those calculated for the central and southern High Plains aquifers (McMahon and others, 2004a, b), but they are at least 10 times smaller than the median rates north of the river (Lincoln Co. \#1 and \#4 and McPherson Co. \#1). The much faster rates of $\mathrm{O}_{2}$ reduction and denitrification in sediments north of the river probably are due to the relative abundance of electron donors, such as organic carbon and pyrite, in sediments overlying the Ogallala Group in the Sand Hills (fig. 6), as discussed previously in the section "Dissolved Oxygen" and as indicated by the mass-balance models (Appendix 2). The relatively large denitrification rates in the Sand Hills indicate that the aquifer in that area may have a greater capacity to attenuate $\mathrm{NO}_{3}{ }^{-}$contamination than the aquifer south of the river, depending on rates of ground-water movement in the two areas. Small denitrification rates south of the river indicate that $\mathrm{NO}_{3}{ }^{-}$contamination in that part of the aquifer would likely persist for a longer period of time, as indicated by the presence of dissolved $\mathrm{O}_{2}$ and $\mathrm{NO}_{3}{ }^{-}$and the absence of excess $\mathrm{N}_{2}$, in water from Lincoln Co. \#3-390, which has an apparent age of $15,600{ }^{14} \mathrm{C}$ years (table 6).

Table 7. Apparent rates of dissolved-oxygen reduction and denitrification.

[ $\Delta$ Age, assumed reaction time; $\Delta \mathrm{O}_{2}$, dissolved-oxygen loss; $\mathrm{N}_{2}$, excess nitrogen gas; $\mathrm{N}$, nitrogen; $\mathrm{mg} / \mathrm{L}$, milligrams per liter; mg/L/yr, milligrams per liter per year; <, less than; >, greater than]

\begin{tabular}{ccccccc}
\hline $\begin{array}{c}\text { Well } \\
\text { name }\end{array}$ & $\begin{array}{c}\Delta \text { Age } \\
\text { (years) }\end{array}$ & $\begin{array}{c}\Delta \mathbf{0}_{2} \\
(\mathbf{m g} / \mathbf{L})\end{array}$ & $\begin{array}{c}\mathbf{0}_{2} \text { reduction } \\
\text { rate }(\mathbf{m g} / \mathbf{L} / \mathbf{y r})\end{array}$ & $\begin{array}{c}\Delta \text { Age } \\
\text { (years) }\end{array}$ & $\begin{array}{c}\text { Excess } \mathbf{N}_{2} \\
(\mathbf{m g} / \mathbf{L} \text { as } \mathbf{N})\end{array}$ & $\begin{array}{c}\text { Denitrification } \\
\text { rate (mg/L/yr as } \mathbf{~})\end{array}$ \\
\hline Lincoln County \#1-119 & 1,800 & $>6.9$ & $>0.004$ & 900 & 3.16 & 0.004 \\
Lincoln County \#3-110 & 6,200 & 0.1 & .00002 & 3,100 & $<.84$ & $<.0003$ \\
Lincoln County \#3-250 & 7,300 & 1.2 & .0002 & 4,200 & $<.84$ & $<.0002$ \\
Lincoln County \#3-390 & 15,600 & 4.7 & .0003 & 12,500 & $<.84$ & $<.00007$ \\
Lincoln County \#4-359 & 2,100 & $>6.9$ & $>.003$ & 1,050 & 1.85 & .002 \\
McPherson County \#1-330 & 1,800 & $>6.9$ & $>.004$ & 900 & 1.57 & .002 \\
\hline
\end{tabular}




\section{Summary and Conclusions}

The northern High Plains aquifer is the primary source of water used for domestic, industrial, and irrigation purposes in parts of Colorado, Kansas, Nebraska, South Dakota, and Wyoming. Despite the aquifer's importance to the regional economy, fundamental ground-water characteristics, such as vertical gradients in water chemistry and age, remain poorly defined. As part of the U.S. Geological Survey's National Water-Quality Assessment Program, water samples from nested, short-screen monitoring wells installed in the northern High Plains aquifer were analyzed for major ions, nutrients, trace elements, dissolved organic carbon, pesticides, stable and radioactive isotopes, dissolved gases, and other parameters to evaluate vertical gradients in water chemistry and age in the aquifer. Chemical data and tritium and radiocarbon ages show that water in the aquifer was chemically and temporally stratified in the study area, with a relatively thin zone of recently recharged water (less than 50 years) near the water table overlying a thicker zone of older water. In areas where irrigated agriculture was an important land use, the recently recharged ground water was characterized by elevated concentrations of major ions and nitrate and the detection of pesticide compounds. Below the zone of agricultural influence, majorion concentrations exhibited small increases with depth and distance along flow paths because of rock/water interactions. The concentration increases were accounted for primarily by dissolved calcium, sodium, bicarbonate, sulfate, and silica. In general, the chemistry of ground water throughout the aquifer was of high quality. None of the approximately 90 chemical constituents analyzed in each sample exceeded primary drinking-water standards.

Nitrite plus nitrate concentrations at the water table were 0.13 to 3.13 milligrams per liter as nitrogen, and concentrations substantially decreased with depth in the aquifer. Dissolved-gas and nitrogen-isotope data indicate that denitrification in the aquifer removed 0 to 97 percent (average $=$ 50 percent) of the nitrate originally present in recharge. The average amount of nitrate removed by denitrification in the aquifer north of the Platte River (Sand Hills) was substantially greater than the amount removed south of the river (66 as opposed to 0 percent), and the extent of nitrate removal appears to be related to the presence of thick deposits of sediment on top of the Ogallala Group in the Sand Hills that contained electron donors, such as organic carbon and pyrite, to support denitrification.

Mass-balance models indicate that changes in groundwater chemistry along flow paths in the aquifer can be accounted for by small amounts of sodium plagioclase and calcite dissolution; kaolinite and silica precipitation; lignite and pyrite oxidation; oxygen reduction and denitrification; and cation exchange. Mixing with surface water affected the chemistry of ground water in alluvial sediments of the Platte River Valley. Radiocarbon ages in the aquifer, adjusted for carbon mass transfers, ranged from 1,800 to $15,600{ }^{14} \mathrm{C}$ years before present. These results have important implications with respect to development of ground-water resources in the Sand Hills. Most of the water in the aquifer predates modern anthropogenic activity so excessive removal of water by pumping is not likely to be replenished by natural recharge in a meaningful timeframe. Vertical gradients in ground-water age were used to estimate long-term average recharge rates in the aquifer. In most areas, the recharge rates ranged from 0.02 to 0.05 foot per year. The recharge rate was 0.2 foot per year in one part of the aquifer characterized by large downward hydraulic gradients. On average, recharge rates in the Sand Hills were about 8 times larger than those in the central High Plains aquifer. This difference in recharge rates likely results from sandier soils and colder recharge temperatures in the Sand Hills compared to the central High Plains because mean annual precipitation in both study areas are within 5 percent of each other.

Apparent rates of dissolved-oxygen reduction and denitrification were estimated on the basis of decreases in dissolved-oxygen concentrations and increases in concentrations of excess nitrogen gas and ground-water ages along flow paths from the water table to deeper wells. Median rates of dissolved-oxygen reduction and denitrification south of the Platte River were at least 10 times smaller than the median rates north of the river in the Sand Hills. The relatively large denitrification rates in the Sand Hills indicate that the aquifer in that area may have a greater capacity to attenuate nitrate contamination than the aquifer south of the river, depending on rates of ground-water movement in the two areas. Small denitrification rates south of the river indicate that nitrate contamination in that part of the aquifer would likely persist for a longer period of time.

Results from this study show that measurements of vertical gradients in water chemistry and age can provide fundamental baseline information on water chemistry, recharge rates, and biogeochemical reaction rates in aquifers. Initiating similar studies in other principal aquifers of the United States would be a good first step toward developing a geochemical framework for these aquifers based on these important variables. Such a framework could be used to develop better understanding of aquifer susceptibility to contamination and better forecasts of contamination of important receptors of ground water, such as drinking-water wells, streams, lakes, and estuaries.

\section{References Cited}

Aravena, R., Wassenaar, L.I., and Plummer, L.N., 1995, Estimating ${ }^{14} \mathrm{C}$ ground-water ages in a methanogenic aquifer: Water Resources Research, v. 31, p. 2307-2317.

Bard, E., Arnold, M., Fairbanks, R.G., and Hamelin, B., 1993, ${ }^{230} \mathrm{Th}-{ }^{234} \mathrm{U}$ and ${ }^{14} \mathrm{C}$ ages obtained by mass spectrometry on corals: Radiocarbon, v. 35, p. 191-199. 
Bethke, C.M., and Johnson, T.M., 2002, Ground-water age: Ground Water, v. 40, p. 337-339.

Bleed, A.S., and Flowerday, C.A., 1998, An atlas of the Sand Hills: University of Nebraska, Institute of Agriculture and Natural Resources, Conservation and Survey Division Resource Atlas No. 5b, 260 p.

Böhlke, J.K., and Denver, J.M., 1995, Combined use of ground-water dating, chemical, and isotopic analyses to resolve the history and fate of nitrate contamination in two agricultural watersheds, Atlantic Coastal Plain, Maryland: Water Resources Research, v. 31, p. 2319-2339.

Böhlke, J.K., 2002, Groundwater recharge and agricultural contamination: Hydrogeology Journal, v. 10, p. 153-179. [Erratum, 2002, v. 10, p. 438-439.]

Böhlke, J.K., Wanty, R., Tuttle, M., Delin, G., and Landon, M., 2002, Denitrification in the recharge area and discharge area of a transient agricultural nitrate plume in a glacial outwash sand aquifer, Minnesota: Water Resources Research, v. 38, 10.1029/2001WR00063.

Böhlke, J.K., Mroczkowski, S.J., and Coplen, T.B., 2003, Oxygen isotopes in nitrate: new reference materials for ${ }^{18} \mathrm{O}:{ }^{17} \mathrm{O}:{ }^{16} \mathrm{O}$ measurements and observations on nitrate-water equilibration: Rapid Communications in Mass Spectrometry, v. 17, p. 1835-1846.

Böttcher, J., Strebel, O., Voerkelius, S., and Schmidt, H.L., 1990, Using isotope fractionation of nitrate-nitrogen and nitrate-oxygen for evaluation of microbial denitrification in a sandy aquifer: Journal of Hydrology, v. 114, p. 413-424.

Boyce, J.S., Muir, J., Edwards, A.P., Seim, E.C., and Olson, R.A., 1976, Geologic nitrogen in Pleistocene loess of Nebraska: Journal of Environmental Quality, v. 5, p. 93-96.

Busenberg, E., Weeks, E.P., Plummer, L.N., and Bartholomy, R.C., 1993, Age dating ground water by use of chlorofluorocarbons $\left(\mathrm{CCl}_{3} \mathrm{~F}\right.$ and $\left.\mathrm{CCl}_{2} \mathrm{~F}_{2}\right)$ and distribution of chlorofluorocarbons in the unsaturated zone, Snake River Plain aquifer, Idaho National Engineering Laboratory, Idaho, USA: U.S. Geological Survey Water-Resources Investigations Report 93-4054, 47 p.

Carmody, R.W., Plummer, L.N., Busenberg, E., and Coplen, T.B., 1997, Methods for collection of dissolved sulfate and sulfide and analysis of their sulfur isotopic compositions: U.S. Geological Survey Open-File Report 97-234, 91 p.

Casciotti, K. L., Sigman, D. M., Hastings, M., Böhlke, J.K., and Hilkert, A., 2002, Measurement of the oxygen isotopic composition of nitrate in seawater and freshwater using the denitrifier method: Analytical Chemistry, v. 74, p. 4905-4912.
Cook, P.G., and Böhlke, J.K., 2000, Determining timescales for groundwater flow and solute transport, in Cook, P.G., and Herczeg, A.L., eds., Environmental tracers in subsurface hydrology: Boston, Kluwer Academic Publishers, p. 1-30.

Coplen, T.B., 1988, Normalization of oxygen and hydrogen isotope data: Chemical Geology, v. 72, p. 293-297.

Coplen, T.B., Wildman, J.D., and Chen, J., 1991, Improvements in the gaseous hydrogen-water equilibration technique for hydrogen isotope ratio analysis: Analytical Chemistry, v. 63, p. 910-912.

Coplen, T.B., and Krouse, H.R., 1998, Sulfur isotope data consistency improved: Nature, v. 392, p. 32.

Diffendal, R.F., Jr., and Goeke, J.W., 2000, Keith County testhole logs: University of Nebraska, Institute of Agriculture and Natural Resources, Conservation and Survey Division Resource THR-51, 115 p.

Dreeszen, V.H., 2000, Perkins County test-hole logs: University of Nebraska, Institute of Agriculture and Natural Resources, Conservation and Survey Division Resource THR-68, $112 \mathrm{p}$.

Druliner, A.D., Chen, H.H., and McGrath, T.S., 1996, Relations of nonpoint-source nitrate and atrazine concentrations in the High Plains aquifer to selected explanatory variables in six Nebraska study areas: U.S. Geological Survey WaterResources Investigations Report 95-4202, 51 p.

Druliner, A.D., 1997, Water quality and chemical evolution of ground water in the Long Pine Creek area, Brown and Rock Counties, Nebraska, 1993-94: U.S. Geological Survey Water-Resources Investigations Report 96-4095, 47 p.

Engberg, R.A., and Spalding, R.F., 1978, Ground-water quality atlas of Nebraska: University of Nebraska, Institute of Agriculture and Natural Resources, Conservation and Survey Division Resource Atlas No. 3, 38 p.

Engberg, R.A., 1984, Appraisal of data for ground-water quality in Nebraska: U.S. Geological Survey Water-Supply Paper 2245, 54 p.

Emmons, P.J., and Bowman, P.R., 2000, Ground-water flow and water quality of the Indian Island well field near Grand Island, Nebraska, 1994-95: U.S. Geological Survey Fact Sheet FS-179-99, 4 p.

Epstein, S., and Mayeda, T., 1953, Variations of O-18 content of water from natural sources: Geochimica et Cosmochimica Acta, v. 4, p. 213-224.

Exner, M.E., and Spalding, R.F., 1990, Occurrence of pesticides and nitrate in Nebraska's ground water: University of Nebraska, Institute of Agriculture and Natural Resources, Water Center Report WC-1, 34 p. 
Fan, A.M., and Steinberg, V.E., 1996, Health implications of nitrate and nitrite in drinking water-An update on methemoglobinemia occurrence and reproductive and developmental toxicity: Regulatory Toxicology and Pharmacology, v. 23 , p. 35-43.

Feagas, R.G., Claire, R.W., Guptill, S.C., Anderson, K.E., and Hallam, C.A., 1983, Land use and land cover digital data: U.S. Geological Survey Circular 895-E, 21 p.

Fishman, M.J., 1993, Methods of analysis by the U.S. Geological Survey National Water Quality Laboratory-Determination of inorganic and organic constituents in water and fluvial sediments: U.S. Geological Survey Open-File Report 93-125, 217 p.

Fontes, J.-Ch., and Garnier, J.-M., 1979, Determination of the initial ${ }^{14} \mathrm{C}$ activity of the total dissolved carbon: a review of the existing models and a new approach: Water Resources Research, v. 15, p. 399-413.

Gilliom, R.J., Alley, W.M., and Gurtz, M.E., 1995, Design of the National Water-Quality Assessment Program-Occurrence and distribution of water-quality conditions: U.S. Geological Survey Circular 1112, 33 p.

Goeke, J.W., 2001, Lincoln County test-hole logs: University of Nebraska, Institute of Agriculture and Natural Resources, Conservation and Survey Division Resource THR-56, $200 \mathrm{p}$.

Goeke, J.W., 2000, McPherson County test-hole logs: University of Nebraska, Institute of Agriculture and Natural Resources, Conservation and Survey Division Resource THR-60, $54 \mathrm{p}$.

Gosselin, D.C., Headrick, J., Tremblay, R., Chen, X.H., and Summerside, S., 1997a, Domestic well-water quality in rural Nebraska—Focus on nitrate-nitrogen, pesticides, and coliform bacteria: Ground Water Monitoring and Remediation, v. 17 , p. $77-87$.

Gosselin, D.C., Nabelek, P.E., Peterman, Z.E., and Sibray, S., 1997b, A reconnaissance study of oxygen, hydrogen, and strontium isotopes in geochemically diverse lakes, Western Nebraska, USA: Journal of Paleolimnology, v. 17, p. 51-65.

Gottula, J.J., 1996, A study of nonpoint source ground-water contamination in the northern portion of the middle Republican Natural Resources District, Nebraska-A Special Protection Area report: Nebraska Department of Environmental Quality, Water Quality Division, Ground Water Section, March 1996, 80 p.

Granger, J., Sigman, D.M., Needoba, J.A., and Harrison, P.J., 2004, Coupled nitrogen and oxygen isotope fractionation of nitrate during assimilation by cultures of marine phytoplankton: Limnology and Oceanography, v. 49, p. 1763-1773.
Gutentag, E.D., Heimes, F.J., Krothe, N.C., Luckey, R.R., and Weeks, J.B., 1984, Geohydrology of the High Plains aquifer in parts of Colorado, Kansas, Nebraska, New Mexico, Oklahoma, South Dakota, Texas, and Wyoming: U.S. Geological Survey Professional Paper 1400-B, 63 p.

Hach Company, 1992, Water analysis handbook: Loveland, Colo., Hach Chemical Co., 835 p.

Harvey, F.E., and Welker, J.M., 2000, Stable isotope composition of precipitation in the semi-arid north-central portion of the US Great Plains: Journal of Hydrology, v. 238, p. 90-109.

Heaton, T.H.E., 1986, Isotopic studies of nitrogen pollution in the hydrosphere and atmosphere-a review: Chemical Geology, v. 59, p. 87-102.

High Plains Regional Climate Center, 2005, Historical climate data for Nebraska: available online at http://www.hprcc.unl. $e d u /$ (accessed on 12/21/2005).

Holloway, J.M., and Dahlgren, R.A., 1999, Geologic nitrogen in terrestrial biogeochemical cycling: Geology, v. 27, p. 567-570.

Hübner, H., 1986, Isotope effects of nitrogen in the soil and biosphere, in Fritz, P., and Fontes, J.C., eds., Handbook of environmental isotope geochemistry: Amsterdam, Elsevier, v. 2, p. 361-425.

Johnson, M.S., Engberg, R.A., and Goeke, J.E., 1986, Hydrologic data for the southern Sand Hills area, Nebraska: U.S. Geological Survey Open-File Report 86-411, 136 p.

Kalin, R.M., 2000, Radiocarbon dating of groundwater systems, in Cook, P.G., and Herczeg, A.L., eds., Environmental tracers in subsurface hydrology: Boston, Kluwer Academic Publishers, p. 111-144.

Kaufman, S., and Libby, W.F., 1954, The natural distribution of tritium: Physics Review, v. 93, p. 1337-1344.

Keys, W.S., 1990, Borehole geophysics applied to groundwater investigations: U.S. Geological Survey Techniques of Water-Resources Investigations, book 2, chap. E2, 150 p.

Knox, M., Quay, P.D., and Wilbur, D., 1992, Kinetic isotopic fractionation during air-water gas transfer of $\mathrm{O}_{2}, \mathrm{~N}_{2}, \mathrm{CH}_{4}$, and $\mathrm{H}_{2}$ : Journal of Geophysical Research, v. 97, issue C12, p. $20,335-20,343$.

Koterba, M.T., Wilde, F.D., and Lapham, W.W., 1995, Ground-water data-collection protocols and procedures for the National Water-Quality Assessment Program-Collection and documentation of water-quality samples and related data: U.S. Geological Survey Open-File Report 95-399, $113 \mathrm{p}$. 
Kreitler, C.W., 1979, Nitrogen-isotope ratio studies of soils and groundwater nitrate from alluvial fan aquifers in Texas: Journal of Hydrology, v. 42, p. 147-170.

Krothe, N.C., Oliver, J.W., and Weeks, J.B., 1982, Dissolved solids and sodium in water from the High Plains aquifer in parts of Colorado, Kansas, Nebraska, New Mexico, Oklahoma, South Dakota, Texas, and Wyoming: U.S. Geological Survey Hydrologic Investigations Atlas 658, 2 sheets.

Krouse, H.R., and Mayer, B., 2000, Sulfur and oxygen isotopes in sulfate, in Cook, P.G., and Herczeg, A.L., eds., Environmental tracers in subsurface hydrology: Boston, Kluwer Academic Publishers, p. 195-231.

Lapham, W.W., Wilde, F.D., and Koterba, M.T., 1995, Ground-water data-collection protocols and procedures for the National Water-Quality Assessment Program-Selection, installation, and documentation of wells, and collection of related data: U.S. Geological Survey Open-File Report 95-398, 69 p.

Litke, D.W., 2001, Historical water-quality data for the High Plains Regional Ground-Water Study Area in Colorado, Kansas, Nebraska, New Mexico, Oklahoma, South Dakota, Texas, and Wyoming, 1930-98: U.S. Geological Survey Water-Resources Investigations Report 00-4254, 65 p.

Luckey, R.R., Gutentag, E.D., Heimes, F.J., and Weeks, J.B., 1986, Digital simulation of ground-water flow in the High Plains aquifer in parts of Colorado, Kansas, Nebraska, New Mexico, Oklahoma, South Dakota, Texas, and Wyoming: U.S. Geological Survey Professional Paper 1400-D, 57 p.

Ludin, A., Weppernig, R., Bönisch, G., and Schlosser, P., 1998, Mass spectrometric measurement of helium isotopes and tritium in water samples: Lamont-Doherty Technical Report 98-06, [http://www.ldeo.columbia.edu/ etg/ms_ms/ Ludin_et_al_MS_Paper.html].

Maupin, M.A. and Barber, N.L., 2005, Estimated withdrawals from principal aquifers in the United States, 2000: U.S. Geological Survey Circular 1279, 46 p.

Mazaud, A., Laj, C., Bard, E., Arnold, M., and Tric, E., 1991, Geomagnetic field control of ${ }^{14} \mathrm{C}$ production over the last 80 ky-implications for the radiocarbon time scale: Geophysical Research Letters, v. 18, p. 1885-1888.

McGuire, V.L., and Sharpe, J.B., 1997, Water-level changes in the High Plains aquifer-Predevelopment to 1995: U.S. Geological Survey Water-Resources Investigations Report 97-4081, 2 sheets.

McMahon, P.B., Chapelle, F.H., and Jagucki, M.L., 1992, Atrazine mineralization potential of alluvial aquifer sediments under aerobic conditions: Environmental Science \& Technology, v. 26, p. 1556-1559.

McMahon, P.B., 2001, Vertical gradients in water chemistry in the central High Plains aquifer, southwestern Kansas and Oklahoma Panhandle, 1999: U.S. Geological Survey WaterResources Investigations Report 01-4028, 47 p.
McMahon, P.B., Böhlke, J.K., and Christenson, S.C., 2004a, Geochemistry, radiocarbon ages, and paleorecharge conditions along a transect in the central High Plains aquifer, southwestern Kansas, USA: Applied Geochemistry, v. 19, p. 1655-1686.

McMahon, P.B., Böhlke, J.K., and Lehman, T.M., 2004b, Vertical gradients in water chemistry and age in the southern High Plains aquifer, Texas, 2002: U.S. Geological Survey Scientific Investigations Report 2004-5053, 53 p.

McMahon, P.B., Dennehy, K.F., Bruce, B.W., Böhlke, J.K., Michel, R.L., Gurdak, J.J., and Hurlbut, D.A., 2006, Storage and transit time of chemicals in thick unsaturated zones under rangeland and irrigated cropland in the High Plains, United States: Water Resources Research, v. 42, W03413, doi:10.1029/2005WR004417.

McMahon, P.B., and Böhlke, J.K., 2006, Regional patterns in the isotopic composition of natural and anthropogenic nitrate in ground water, High Plains, USA: Environmental Science \& Technology, v. 40, p. 2965-2970.

McNutt, R.H., 2000, Strontium isotopes, in Cook, P.G., and Herczeg, A.L., eds., Environmental tracers in subsurface hydrology: Boston, Kluwer Academic Publishers, p. 233-260.

National Atmospheric Deposition Program, 2005, National Trends Network: available online at http://nadp.sws.uiuc. edu (accessed on 1/4/2006).

Parkhurst, D.L., and Appelo, C.A.J., 1999, User's guide to PHREEQC (ver. 2) - A computer program for speciation, batch reaction, one-dimensional transport, and inverse geochemical calculations: U.S. Geological Survery WaterResources Investigations Report 99-4259, 312 p.

Plummer, L.N., Busby, J.F., Lee, R.W., and Hanshaw, B.B., 1990, Geochemical modeling of the Madison aquifer in parts of Montana, Wyoming, and South Dakota: Water Resources Research, v. 26, p. 1981-2014.

Plummer, L.N., Prestemon, E.C., and Parkhurst, D.L., 1994, An interactive code (NETPATH) for modeling NET geochemical reactions along a flow PATH, version 2.13: U.S. Geological Survey Water Resources-Investigations Report 94-4169, $130 \mathrm{p}$.

Plummer, L.N., Bexfield, L.M., Anderholm, S.K., Sanford, W.E., and Busenberg, E., 2004, Geochemical characterization of ground-water flow in the Santa Fe Group aquifer system, Middle Rio Grande Basin, New Mexico: U.S. Geological Survey Water-Resources Investigations Report 03-4131, $395 \mathrm{p}$.

Postma, D., Boesen, C., Kristiansen, H., and Larsen, F., 1991, Nitrate reduction in an unconfined sandy aquifer-water chemistry, reduction processes, and geochemical modeling: Water Resources Research, v. 27, p. 2027-2045. 
Qi, S.L., Konduris, A., Litke, D.W., and Dupree, J., 2002, Classification of irrigated land using satellite imagery, the High Plains aquifer, nominal date 1992: U.S. Geological Survey Water-Resources Investigations Report 02-4236, $35 \mathrm{p}$.

Smedley, P.L., and Kinniburgh, D.G., 2002, A review of the source, behavior, and distribution of arsenic in natural waters: Applied Geochemistry, v. 17, p. 517-568.

Spalding, R.F., Exner, M.E., Martin, G.E., and Snow, D.D., 1993, Effects of sludge disposal on ground-water nitrate concentrations: Journal of Hydrology, v. 142, p. 213-228.

Spalding, R.F., Watts, D.G., Schepers, J.S., Burbach, M.E., Exner, M.E., Poreda, R.J., and Martin, G.E., 2001, Controlling nitrate leaching in irrigated agriculture: Journal of Environmental Quality, v. 30, p. 1184-1194.

Stanton, J.S., 2006, Ground-water quality of the northern High Plains aquifer, 1997, 2002-04: U.S. Geological Survey Scientific Investigations Report 2006-5138, x p.

Steele, G.V., Cannia, J.C., and Stanton, J.S., 1998, Geohydrology and water quality of the North Platte River alluvial aquifer, Garden County, western Nebraska, 1993-94: U.S. Geological Survey Water-Resources Investigations Report 98-4033, 75 p.

Stumm, W., and Morgan, J.J., 1981, Aquatic Chemistry: John Wiley \& Sons, New York, New York, 780 p.

Stute, M., and Schlosser, P., 1993, Principles and applications of the noble gas paleothermometer, in Swart, P.K., Lohmann, K.C., McKenzie, J., and Savin, S., eds., Climate change in continental isotope records: Geophysical Monograph 78, p. $89-100$.

Swinehart, J.B., and Diffendal, R.F., 1998, Geology of the pre-dune strata, in Bleed, A.S., and Flowerday, C.A., eds., An Atlas of the Sand Hills: University of Nebraska, Institute of Agriculture and Natural Resources, Conservation and Survey Division Resource Atlas No. 5b, p. 29-42.

Swinehart, J.B., 1998, Wind-blown deposits, in Bleed, A.S., and Flowerday, C.A., eds., An Atlas of the Sand Hills: University of Nebraska, Institute of Agriculture and Natural Resources, Conservation and Survey Division Resource Atlas No. 5b, p. 43-56.

Thatcher, L.L., 1962, The distribution of tritium fallout in precipitation over North America: Bulletin of the International Association of Scientific Hydrology, v. 7, p. 48-58.
Thatcher, L.L., Janzer, V.J., and Edwards, K.W., 1977, Methods for determination of radioactive substances in water and fluvial sediments: U.S. Geological Survey Techniques of Water-Resources Investigations, chap. A-5, 95 p.

U.S. Department of Agriculture, 2002, 2002 Census of Agriculture: available online at http://www.nass.usda.gov/ Census_of_Agriculture/index.asp (accessed in 1/12/2006).

U.S. Environmental Protection Agency, 1999, National Primary Drinking-Water Regulations; Radon-222: available online at $h t t p: / / w w w . e p a . g o v /$ safewater/radon/radfr2.html (accessed on 12/19/2005).

U.S. Environmental Protection Agency, 2006, National Primary Drinking-Water Regulations: available online at http://www.epa.gov/safewater/mcl.html\#listmcl (accessed on 10/20/2006).

U.S. Geological Survey, variously dated, National field manual for the collection of water-quality data: U.S. Geological Survey Techniques of Water-Resources Investigations, book 9, chaps. A1-A9, available online at http://pubs.water.usgs. gov/twri9A (accessed on 12/19/2005).

Verstraeten, I.M., Sibray, S.S., Cannia, J.C., and Tanner, D.Q., 1995, Reconnaissance of ground-water quality in the North Platte Natural Resources District, western Nebraska, June-July 1991: U.S. Geological Survey Water-Resources Investigations Report 94-4057, 114 p.

Verstraeten, I.M., Böhlke, J.K., Kraemer, T.F., and Cannia, J.C., 2001, Use of environmental tracers and isotopes to evaluate sources of water, nitrate, and uranium in an irrigated alluvial valley, Nebraska: U.S. Geological Survey Fact Sheet FS-100-01, 4 p.

Weissmann, G.S., Zhang, Y., LaBolle, E.M., and Fogg, G.E., 2002, Dispersion of ground-water age in an alluvial aquifer system: Water Resources Research, v. 38, 1198, doi:10.1029/2001WR000907.Zaugg, S.D., Sandstrom, M.W., Smith, S.G., and Fehlberg, K.M., 1995, Methods of analysis by the U.S. Geological Survey National Water Quality Laboratory-Determination of pesticides in water by $\mathrm{C}-18$ solid-phase extraction and capillary-column gas chromatography/mass spectrometry with selected-ion monitoring: U.S. Geological Survey Open-File Report 95-181, $60 \mathrm{p}$. 


\section{Appendix 1}

Water-Quality Data from Sampled Monitoring

Wells Screened in the Northern High Plains

Aquifer and from the Platte River 
Appendix 1. Water-quality data from sampled monitoring wells screened in the northern High Plains aquifer and from the Platte River near Brady, Nebraska.

$\left[\mathrm{mg} / \mathrm{L}\right.$, milligrams per liter; $\mu \mathrm{S} / \mathrm{cm}$, microsiemens per centimeter at $25^{\circ} \mathrm{C} ;{ }^{\circ} \mathrm{C}$, degrees Celsius; $\mathrm{CaCO}_{3}$, calcium carbonate; <, less than; $\mathrm{N}$, nitrogen; $\mathrm{P}$, phosphorus; $\mathrm{NTU}$, nephelometric turbidity units; $\mu \mathrm{g} / \mathrm{L}$, micrograms per liter; $\mathrm{pCi} / \mathrm{L}$, picocuries per liter; --, no data; E, estimated]

\begin{tabular}{|c|c|c|c|c|c|c|c|c|c|c|}
\hline $\begin{array}{c}\text { Well/ } \\
\text { site name }\end{array}$ & $\begin{array}{l}\text { Sampling } \\
\text { date }\end{array}$ & $\begin{array}{c}\text { Turbidity } \\
\text { (NTU) }\end{array}$ & $\begin{array}{c}\text { Oxygen } \\
\left(\mathrm{O}_{2}\right) \text {, dis- } \\
\text { solved } \\
(\mathrm{mg} / \mathrm{L})\end{array}$ & $\begin{array}{c}\text { pH, } \\
\text { field } \\
\text { (standard } \\
\text { units) }\end{array}$ & $\begin{array}{c}\text { Specific } \\
\text { conduc- } \\
\text { tance } \\
(\mu \mathrm{S} / \mathrm{cm})\end{array}$ & $\begin{array}{c}\text { Water } \\
\text { tempera- } \\
\text { ture } \\
\left({ }^{\circ} \mathrm{C}\right)\end{array}$ & $\begin{array}{l}\text { Hydrogen } \\
\text { sulfide } \\
\left.\text { ( } \mathrm{H}_{2} \mathrm{~S}\right) \text {, } \\
\text { field, total } \\
\text { (mg/L) }\end{array}$ & $\begin{array}{c}\text { Calcium (Ca), } \\
\text { dissolved } \\
\text { (mg/L) }\end{array}$ & $\begin{array}{l}\text { Magnesium } \\
\text { (Mg), } \\
\text { dissolved } \\
(\mathrm{mg} / \mathrm{L})\end{array}$ & $\begin{array}{l}\text { Potassium } \\
\text { (K), } \\
\text { dissolved } \\
\text { (mg/L) }\end{array}$ \\
\hline Platte River near Brady, Nebr. & $10 / 12 / 04$ & -- & 9.5 & 8.4 & 620 & 19.3 & -- & 63.0 & 16.2 & 11.5 \\
\hline Imperial & $9 / 4 / 02$ & 1.8 & 9.3 & 7.49 & 318 & 15.7 & -- & 46.2 & 7.38 & 7.68 \\
\hline Keith County \#1 & $9 / 20 / 05$ & 0.6 & 7.4 & 7.4 & 393 & 16.3 & -- & 52.6 & 10.2 & 10.3 \\
\hline Lincoln County \#1-25 & $9 / 6 / 03$ & .2 & $<.5$ & 7.75 & 301 & 13.7 & -- & 37.7 & 6.12 & 8.00 \\
\hline Lincoln County \#1-119 & $9 / 5 / 03$ & .2 & $<.5$ & 7.77 & 284 & 14.0 & $<0.01$ & 39.7 & 6.08 & 5.43 \\
\hline Lincoln County \#1-270 & $9 / 5 / 03$ & .2 & $<.5$ & 7.79 & 275 & 15.3 & $<.01$ & 38.1 & 6.02 & 6.08 \\
\hline Lincoln County \#1-370 & $9 / 6 / 03$ & 3.8 & 1.5 & 7.78 & 354 & 15.4 & -- & 35.3 & 6.17 & 10.2 \\
\hline Lincoln County \#2-255 & $9 / 7 / 03$ & .3 & 7.8 & 7.43 & 151 & 14.9 & -- & 16.2 & 2.24 & 4.73 \\
\hline Lincoln County \#2-590 & $9 / 7 / 03$ & 7.2 & $<.5$ & 7.65 & 360 & 16.7 & $<.01$ & 47.6 & 6.26 & 10.5 \\
\hline Lincoln County \#2-760 & $9 / 7 / 03$ & 5.1 & 2.9 & 7.78 & 293 & 16.8 & -- & 37.7 & 4.49 & 8.05 \\
\hline Lincoln County \#3-30 & $9 / 4 / 03$ & .1 & 3.6 & 7.55 & 610 & 11.4 & -- & 71.7 & 15.7 & 9.00 \\
\hline Lincoln County \#3-110 & $9 / 3 / 03$ & .7 & 7.3 & 7.69 & 386 & 12.2 & -- & 48.1 & 10.7 & 10.7 \\
\hline Lincoln County \#3-250 & $9 / 4 / 03$ & .5 & 6.2 & 7.68 & 393 & 13.3 & -- & 41.0 & 7.88 & 9.83 \\
\hline Lincoln County \#3-390 & $9 / 3 / 03$ & .9 & 2.7 & 7.65 & 490 & 13.7 & -- & 47.4 & 10.2 & 12.4 \\
\hline
\end{tabular}


Appendix 1. Water-quality data from sampled monitoring wells screened in the northern High Plains aquifer and from the Platte River near Brady, Nebraska. - Continued

$\left[\mathrm{mg} / \mathrm{L}\right.$, milligrams per liter; $\mu \mathrm{S} / \mathrm{cm}$, microsiemens per centimeter at $25^{\circ} \mathrm{C} ;{ }^{\circ} \mathrm{C}$, degrees Celsius; $\mathrm{CaCO}_{3}$, calcium carbonate; <, less than; $\mathrm{N}$, nitrogen; $\mathrm{P}$, phosphorus; $\mathrm{NTU}$, nephelometric turbidity units; $\mu \mathrm{g} / \mathrm{L}$, micrograms per liter; $\mathrm{pCi} / \mathrm{L}$, picocuries per liter; --, no data; E, estimated]

\begin{tabular}{|c|c|c|c|c|c|c|c|c|c|c|}
\hline $\begin{array}{c}\text { Well/ } \\
\text { site name }\end{array}$ & $\begin{array}{l}\text { Sampling } \\
\text { date }\end{array}$ & $\begin{array}{c}\text { Turbidity } \\
\text { (NTU) }\end{array}$ & $\begin{array}{c}\text { Oxygen } \\
\left(\mathrm{O}_{2}\right) \text {, dis- } \\
\text { solved } \\
(\mathrm{mg} / \mathrm{L})\end{array}$ & $\begin{array}{c}\text { pH, } \\
\text { field } \\
\text { (standard } \\
\text { units) }\end{array}$ & $\begin{array}{c}\text { Specific } \\
\text { conduc- } \\
\text { tance } \\
(\mu \mathrm{S} / \mathrm{cm})\end{array}$ & $\begin{array}{l}\text { Water } \\
\text { tempera- } \\
\text { ture } \\
\left({ }^{\circ} \mathrm{C}\right)\end{array}$ & $\begin{array}{l}\text { Hydrogen } \\
\text { sulfide } \\
\left(\mathrm{H}_{2} \mathrm{~S}\right) \text {, } \\
\text { field, total } \\
\text { (mg/L) }\end{array}$ & $\begin{array}{c}\text { Calcium (Ca), } \\
\text { dissolved } \\
\text { (mg/L) }\end{array}$ & $\begin{array}{l}\text { Magnesium } \\
\text { (Mg), } \\
\text { dissolved } \\
\text { (mg/L) }\end{array}$ & $\begin{array}{l}\text { Potassium } \\
\text { (K), } \\
\text { dissolved } \\
\text { (mg/L) }\end{array}$ \\
\hline Lincoln County \#4-195 & $10 / 22 / 03$ & .2 & 7.3 & 7.25 & 112 & 14.7 & -- & 12.8 & 1.85 & 5.06 \\
\hline Lincoln County \#4-359 & $10 / 23 / 03$ & .2 & $<.5$ & 7.87 & 188 & 15.3 & $<.01$ & 26.5 & 3.19 & 5.65 \\
\hline Lincoln County \#4-510 & $10 / 22 / 03$ & .2 & $<.5$ & 7.76 & 233 & 16.6 & $<.01$ & 33.8 & 4.07 & 7.06 \\
\hline Lincoln County \#4-695 & $10 / 22 / 03$ & .5 & $<.5$ & 7.61 & 346 & 17.5 & $<.01$ & 37.3 & 5.15 & 11.8 \\
\hline McPherson County \#1-45 & $9 / 8 / 03$ & .2 & 7.1 & 7.58 & 131 & 11.9 & -- & 15.5 & 1.59 & 4.07 \\
\hline McPherson County \#1-330 & $9 / 9 / 03$ & .4 & $<.5$ & 7.84 & 226 & 13.2 & $<.01$ & 27.8 & 3.67 & 4.99 \\
\hline McPherson County \#1-550 & $9 / 9 / 03$ & 1.4 & $<.5$ & 7.48 & 393 & 14.2 & $<.01$ & 56.2 & 7.17 & 8.97 \\
\hline McPherson County \#1-770 & $10 / 13 / 04$ & .2 & $<.5$ & 7.37 & 378 & 14.3 & $<.01$ & 48.8 & 5.53 & 7.30 \\
\hline
\end{tabular}


Appendix 1. Water-quality data from sampled monitoring wells screened in the northern High Plains aquifer and from the Platte River near

Brady, Nebraska. - Continued

$\left[\mathrm{mg} / \mathrm{L}\right.$, milligrams per liter; $\mu \mathrm{S} / \mathrm{cm}$, microsiemens per centimeter at $25^{\circ} \mathrm{C} ;{ }^{\circ} \mathrm{C}$, degrees Celsius; $\mathrm{CaCO}_{3}$, calcium carbonate; <, less than; N, nitrogen; P, phosphorus; NTU, nephelometric turbidity units; $\mu \mathrm{g} / \mathrm{L}$, micrograms per liter; $\mathrm{pCi} / \mathrm{L}$, picocuries per liter; --, no data; $\mathrm{E}$, estimated]

\begin{tabular}{|c|c|c|c|c|c|c|c|c|c|c|}
\hline $\begin{array}{c}\text { Well/ } \\
\text { site name }\end{array}$ & $\begin{array}{l}\text { Sodium } \\
\text { ( } \mathrm{Na}), \text { dis- } \\
\text { solved } \\
\text { (mg/L) }\end{array}$ & $\begin{array}{c}\text { Alkalinity, } \\
\text { dissolved } \\
\text { (mg/L as } \\
\mathrm{CaCO}_{3} \text { ) }\end{array}$ & $\begin{array}{c}\text { Bromide } \\
\text { (Br), dis- } \\
\text { solved } \\
\text { (mg/L) }\end{array}$ & $\begin{array}{c}\text { Chloride } \\
\text { (CI), dis- } \\
\text { solved } \\
\text { (mg/L) }\end{array}$ & $\begin{array}{c}\text { Fluoride } \\
\text { (F), dis- } \\
\text { solved } \\
\text { (mg/L) }\end{array}$ & $\begin{array}{c}\text { Silica } \\
\left(\mathrm{SiO}_{2}\right), \\
\text { dissolved } \\
(\mathrm{mg} / \mathrm{L})\end{array}$ & $\begin{array}{c}\text { Sulfate } \\
\left(\mathrm{SO}_{4}\right), \\
\text { dissolved } \\
\text { (mg/L) }\end{array}$ & $\begin{array}{l}\text { Dissolved } \\
\text { solids, } \\
\text { residue } \\
\text { at } 180^{\circ} \mathrm{C} \\
\text { (mg/L) }\end{array}$ & $\begin{array}{l}\text { Nitrogen, } \\
\text { ammonium } \\
\left(\mathrm{NH}_{4}\right) \text {, dis- } \\
\text { solved (mg/L } \\
\text { as } \mathrm{N} \text { ) }\end{array}$ & $\begin{array}{c}\text { Nitrogen, } \\
\text { ammonia } \\
\text { + organic, } \\
\text { dissolved } \\
\text { (mg/L } \\
\text { as } \mathrm{N} \text { ) }\end{array}$ \\
\hline $\begin{array}{l}\text { Platte River near Brady, } \\
\text { Nebr. }\end{array}$ & 47.3 & 177 & 0.067 & 15.8 & 0.5 & 36.6 & 120. & 427 & $<0.04$ & -- \\
\hline Imperial & 6.29 & 142 & E.03 & 2.03 & .6 & 58.0 & 5.8 & 238 & $<.04$ & E0.06 \\
\hline Keith County \#1 & 11.7 & 157 & .22 & 8.26 & .5 & 58.7 & 17.9 & 284 & $<.04$ & -- \\
\hline Lincoln County \#1-25 & 10.4 & 138 & E. 010 & 1.51 & .5 & 56.7 & 11.0 & 220 & $<.04$ & $<.1$ \\
\hline Lincoln County \#1-119 & 7.67 & 134 & .025 & 1.08 & .4 & 61.2 & 6.6 & 215 & $<.04$ & $<.1$ \\
\hline Lincoln County \#1-270 & 6.91 & 130 & .025 & .93 & .3 & 62.8 & 7.1 & 208 & $<.04$ & $<.1$ \\
\hline Lincoln County \#1-370 & 25.3 & 150 & .025 & 1.15 & .6 & 67.5 & 21.2 & 264 & $<.04$ & $<.1$ \\
\hline Lincoln County \#2-255 & 6.06 & 65.6 & .015 & .92 & .3 & 48.6 & 1.9 & 124 & $<.41$ & $<.1$ \\
\hline Lincoln County \#2-590 & 17.5 & 162 & .025 & 1.37 & .3 & 65.3 & 16.6 & 422 & $<.41$ & $<.1$ \\
\hline Lincoln County \#2-760 & 14.8 & 133 & .021 & 1.28 & .3 & 59.5 & 11.4 & 213 & $<.04$ & $<.1$ \\
\hline Lincoln County \#3-30 & 23.8 & 194 & .078 & 10.7 & .3 & 56.9 & 93.1 & 433 & $<.04$ & $<.1$ \\
\hline Lincoln County \#3-110 & 14.2 & 168 & .050 & 2.45 & .5 & 56.9 & 17.4 & 286 & $<.04$ & $<.1$ \\
\hline Lincoln County \#3-250 & 26.2 & 159 & .042 & 4.08 & .6 & 64.1 & 29.7 & 291 & $<.04$ & $<.1$ \\
\hline Lincoln County \#3-390 & 35.1 & 170 & .064 & 7.15 & .6 & 59.8 & 60.2 & 349 & $<.04$ & $<.1$ \\
\hline
\end{tabular}


Appendix 1. Water-quality data from sampled monitoring wells screened in the northern High Plains aquifer and from the Platte River near

Brady, Nebraska. - Continued

$\left[\mathrm{mg} / \mathrm{L}\right.$, milligrams per liter; $\mu \mathrm{S} / \mathrm{cm}$, microsiemens per centimeter at $25^{\circ} \mathrm{C} ;{ }^{\circ} \mathrm{C}$, degrees Celsius; $\mathrm{CaCO}_{3}$, calcium carbonate; <, less than; N, nitrogen; $\mathrm{P}$, phosphorus; NTU, nephelometric turbid-

ity units; $\mu \mathrm{g} / \mathrm{L}$, micrograms per liter; pCi/L, picocuries per liter; --, no data; E, estimated]

\begin{tabular}{|c|c|c|c|c|c|c|c|c|c|c|}
\hline $\begin{array}{c}\text { Well/ } \\
\text { site name }\end{array}$ & $\begin{array}{l}\text { Sodium } \\
\text { ( } \mathrm{Na}), \text { dis- } \\
\text { solved } \\
\text { (mg/L) }\end{array}$ & $\begin{array}{c}\text { Alkalinity, } \\
\text { dissolved } \\
\text { (mg/L as } \\
\left.\mathrm{CaCO}_{3}\right)\end{array}$ & $\begin{array}{c}\text { Bromide } \\
\text { (Br), dis- } \\
\text { solved } \\
\text { (mg/L) }\end{array}$ & $\begin{array}{c}\text { Chloride } \\
\text { (CI), dis- } \\
\text { solved } \\
\text { (mg/L) }\end{array}$ & $\begin{array}{l}\text { Fluoride } \\
\text { (F), dis- } \\
\text { solved } \\
\text { (mg/L) }\end{array}$ & $\begin{array}{c}\text { Silica } \\
\left(\mathrm{SiO}_{2}\right), \\
\text { dissolved } \\
\text { (mg/L) }\end{array}$ & $\begin{array}{c}\text { Sulfate } \\
\left(\mathrm{SO}_{4}\right), \\
\text { dissolved } \\
\text { (mg/L) }\end{array}$ & $\begin{array}{c}\text { Dissolved } \\
\text { solids, resi- } \\
\text { due at } \\
180^{\circ} \mathrm{C} \\
\text { (mg/L) }\end{array}$ & $\begin{array}{c}\text { Nitrogen, } \\
\text { ammonium } \\
\left(\mathrm{NH}_{4}\right) \text {, dis- } \\
\text { solved (mg/L } \\
\text { as } \mathrm{N} \text { ) }\end{array}$ & $\begin{array}{c}\text { Nitrogen, } \\
\text { ammonia } \\
\text { + organic, } \\
\text { dissolved } \\
\text { (mg/L } \\
\text { as } \mathrm{N} \text { ) }\end{array}$ \\
\hline Lincoln County \#4-195 & 5.67 & 47.4 & 0.014 & 0.74 & .2 & 54.6 & 3.0 & 118 & $<.04$ & $<.1$ \\
\hline Lincoln County \#4-359 & 6.55 & 89.6 & .016 & 0.75 & .3 & 58.4 & 3.1 & 152 & $<.04$ & $<.1$ \\
\hline Lincoln County \#4-510 & 7.2 & 108 & .009 & 0.76 & .2 & 63.8 & 9.9 & 189 & $<.04$ & $<.1$ \\
\hline Lincoln County \#4-695 & 29.9 & 163 & .021 & 1.69 & .3 & 76.0 & 17.5 & 263 & $<.04$ & $<.1$ \\
\hline $\begin{array}{l}\text { McPherson County } \\
\# 1-45\end{array}$ & 4.66 & 39.9 & .011 & 1.34 & .2 & 49.3 & 6.2 & 114 & $<.04$ & $<.1$ \\
\hline $\begin{array}{l}\text { McPherson County } \\
\# 1-330\end{array}$ & 8.75 & 108 & .014 & 1.08 & .5 & 56.5 & 2.3 & 175 & $<.04$ & $<.1$ \\
\hline $\begin{array}{l}\text { McPherson County } \\
\# 1-550\end{array}$ & 15.8 & 201 & .028 & 2.02 & .3 & 58.8 & E.1 & 271 & $<.04$ & $<.1$ \\
\hline $\begin{array}{l}\text { McPherson County } \\
\# 1-770\end{array}$ & 12.8 & 114 & .049 & 1.18 & .2 & 65.8 & 19.7 & 236 & $<.04$ & -- \\
\hline
\end{tabular}


Appendix 1. Water-quality data from sampled monitoring wells screened in the northern High Plains aquifer and from the Platte River near Brady,

Nebraska._Continued

$\left[\mathrm{mg} / \mathrm{L}\right.$, milligrams per liter; $\mu \mathrm{S} / \mathrm{cm}$, microsiemens per centimeter at $25^{\circ} \mathrm{C} ;{ }^{\circ} \mathrm{C}$, degrees Celsius; $\mathrm{CaCO}_{3}$, calcium carbonate; <, less than; $\mathrm{N}$, nitrogen; $\mathrm{P}$, phosphorus;

NTU, nephelometric turbidity units; $\mu \mathrm{g} / \mathrm{L}$, micrograms per liter; $\mathrm{pCi} / \mathrm{L}$, picocuries per liter; --, no data; E, estimated]

\begin{tabular}{|c|c|c|c|c|c|c|c|c|}
\hline $\begin{array}{c}\text { Well/ } \\
\text { site name }\end{array}$ & $\begin{array}{c}\text { Nitrogen, } \\
\text { nitrite + nitrate } \\
\left(\mathrm{NO}_{2}+\mathrm{NO}_{3}\right) \text {, dis- } \\
\text { solved (mg/L } \\
\text { as } \mathrm{N})\end{array}$ & $\begin{array}{c}\text { Nitrogen, } \\
\text { nitrite }\left(\mathrm{NO}_{2}\right), \\
\text { dissolved } \\
\text { (mg/L as N) }\end{array}$ & $\begin{array}{c}\text { Phosphorus, } \\
\text { ortho }\left(\mathrm{PO}_{4}\right) \text {, } \\
\text { dissolved } \\
\text { (mg/L as } \mathrm{P})\end{array}$ & $\begin{array}{c}\text { Carbon, } \\
\text { organic, } \\
\text { dis- } \\
\text { solved } \\
\text { (DOC) } \\
\text { (mg/L) }\end{array}$ & $\begin{array}{l}\text { Aluminum } \\
\text { (AI), dissolved } \\
(\mu \mathrm{g} / \mathrm{L})\end{array}$ & $\begin{array}{l}\text { Antimony } \\
(\mathrm{Sb}), \\
\text { dissolved } \\
(\mu \mathrm{g} / \mathrm{L})\end{array}$ & $\begin{array}{l}\text { Arsenic } \\
\text { (As), dis- } \\
\text { solved } \\
\text { ( } \mu \mathrm{g} / \mathrm{L})\end{array}$ & $\begin{array}{c}\text { Barium } \\
\text { (Ba), dissolved } \\
(\mu \mathrm{g} / \mathrm{L})\end{array}$ \\
\hline Platte River near Brady, Nebr. & 0.38 & $<0.008$ & 0.012 & -- & E1.23 & E0.15 & 5.5 & 83 \\
\hline Imperial & 2.40 & $<.008$ & E.01 & 1.0 & -- & -- & -- & -- \\
\hline Keith County \#1 & 2.23 & $<.008$ & 0.01 & -- & E1.1 & E.1 & 5.8 & 121 \\
\hline Lincoln County \#1-25 & 0.13 & $<.008$ & .18 & 0.6 & E1.08 & E. 2 & 7.3 & 117 \\
\hline Lincoln County \#1-119 & 0.85 & .012 & $<.18$ & .4 & E1.03 & E.2 & 5.4 & 168 \\
\hline Lincoln County \#1-270 & 0.89 & $<.008$ & $<.18$ & E.2 & $<1.6$ & $<.3$ & 7.1 & 161 \\
\hline Lincoln County \#1-370 & 1.09 & $<.008$ & $<.18$ & E. 2 & 4.1 & $<.3$ & 8.7 & 82 \\
\hline Lincoln County \#2-255 & 1.11 & $<.008$ & .28 & E. 3 & $<1.6$ & $<.3$ & 9.2 & 65 \\
\hline Lincoln County \#2-590 & 0.49 & $<.008$ & $<.18$ & .4 & 5.1 & $<.3$ & 5.5 & 161 \\
\hline Lincoln County \#2-760 & 0.57 & $<.008$ & $<.18$ & E. 2 & E.95 & E. 2 & 7.9 & 143 \\
\hline Lincoln County \#3-30 & 3.13 & $<.008$ & $<.18$ & .5 & $<1.6$ & $<.3$ & 3.3 & 85 \\
\hline Lincoln County \#3-110 & 2.57 & $<.008$ & $<.18$ & E. 2 & $<1.6$ & $<.3$ & 5.6 & 71 \\
\hline Lincoln County \#3-250 & 1.59 & $<.008$ & $<.18$ & E.2 & $<1.6$ & $<.3$ & 7.3 & 64 \\
\hline Lincoln County \#3-390 & 1.42 & $<.008$ & $<.18$ & .4 & E.90 & $<.3$ & 6.8 & 45 \\
\hline Lincoln County \#4-195 & 1.05 & $<.008$ & .33 & E. 3 & E1.28 & E. 2 & 9.8 & 41 \\
\hline Lincoln County \#4-359 & .12 & $<.008$ & $<.18$ & E. 3 & E1.55 & E.1 & 4.7 & 155 \\
\hline Lincoln County \#4-510 & $<.06$ & $<.008$ & $<.18$ & E. 2 & E.94 & $<.2$ & 5.0 & 131 \\
\hline Lincoln County \#4-695 & .09 & $<.008$ & $<.18$ & .6 & E1.49 & $<.2$ & 6.1 & 150 \\
\hline McPherson County \#1-45 & 2.75 & $<.008$ & .22 & .5 & E1.11 & .4 & 5.0 & 51 \\
\hline McPherson County \#1-330 & $<.06$ & $<.008$ & $<.18$ & .9 & 1.81 & $<.3$ & 5.4 & 71 \\
\hline McPherson County \#1-550 & $<.06$ & $<.008$ & $<.18$ & 1.3 & E. 85 & $<.3$ & 5.2 & 151 \\
\hline McPherson County \#1-770 & .50 & $<.008$ & $<.18$ & .5 & E1.08 & .2 & 5.3 & 168 \\
\hline
\end{tabular}


Appendix 1. Water-quality data from sampled monitoring wells screened in the northern High Plains aquifer and from the Platte River near Brady, Nebraska.-Continued

$\left[\mathrm{mg} / \mathrm{L}\right.$, milligrams per liter; $\mu \mathrm{S} / \mathrm{cm}$, microsiemens per centimeter at $25^{\circ} \mathrm{C} ;{ }^{\circ} \mathrm{C}$, degrees Celsius; $\mathrm{CaCO}_{3}$, calcium carbonate; <, less than; $\mathrm{N}$, nitrogen; $\mathrm{P}$, phosphorus; $\mathrm{NTU}$, nephelometric turbidity units; $\mu \mathrm{g} / \mathrm{L}$, micrograms per liter; $\mathrm{pCi} / \mathrm{L}$, picocuries per liter; --, no data; $\mathrm{E}$, estimated]

\begin{tabular}{|c|c|c|c|c|c|c|c|c|c|}
\hline $\begin{array}{c}\text { Well/ } \\
\text { site name }\end{array}$ & $\begin{array}{l}\text { Beryllium } \\
\text { (Be), } \\
\text { dissolved } \\
(\mu \mathrm{g} / \mathrm{L})\end{array}$ & $\begin{array}{c}\text { Boron } \\
\text { (B), } \\
\text { dissolved } \\
(\mu \mathrm{g} / \mathrm{L})\end{array}$ & $\begin{array}{l}\text { Cadmium } \\
\text { (Cd), dis- } \\
\text { solved } \\
(\mu \mathrm{g} / \mathrm{L})\end{array}$ & $\begin{array}{c}\text { Chromium (Cr), } \\
\text { dissolved } \\
(\mu \mathrm{g} / \mathrm{L})\end{array}$ & $\begin{array}{c}\text { Cobalt } \\
\text { (Co), } \\
\text { dissolved } \\
(\mu \mathrm{g} / \mathrm{L})\end{array}$ & $\begin{array}{l}\text { Copper } \\
\text { (Cu), } \\
\text { dissolved } \\
(\mu \mathrm{g} / \mathrm{L})\end{array}$ & $\begin{array}{c}\text { Iron } \\
\text { (Fe), } \\
\text { dissolved } \\
(\mu \mathrm{g} / \mathrm{L})\end{array}$ & $\begin{array}{c}\text { Lead } \\
(\mathrm{Pb}), \\
\text { dissolved } \\
(\mu \mathrm{g} / \mathrm{L})\end{array}$ & $\begin{array}{l}\text { Lithium } \\
\text { (Li), } \\
\text { dissolved } \\
\text { ( } \mu \mathrm{g} / \mathrm{L} \text { ) }\end{array}$ \\
\hline Platte River near Brady, Nebr. & $<0.06$ & 88 & $<0.04$ & $<0.8$ & 0.24 & 1.8 & $<6$ & $<0.08$ & 22.0 \\
\hline Imperial & -- & -- & -- & -- & -- & -- & -- & -- & -- \\
\hline Keith County \#1 & $<.06$ & 56 & $<.04$ & 1.7 & .04 & E. 3 & $<6$ & $<.08$ & 17.1 \\
\hline Lincoln County \#1-25 & $<.06$ & 38 & $<.04$ & $<.8$ & .33 & 1.8 & 26. & $<.08$ & 11.7 \\
\hline Lincoln County \#1-119 & $<.06$ & 39 & $<.04$ & $<.8$ & .15 & .4 & $<8$ & $<.08$ & 7.3 \\
\hline Lincoln County \#1-270 & $<.06$ & 39 & $<.04$ & $<.8$ & .12 & .5 & $<8$ & $<.08$ & 9.3 \\
\hline Lincoln County \#1-370 & $<.06$ & 77 & $<.04$ & 2.6 & .15 & 1.0 & $<8$ & $<.08$ & 16.7 \\
\hline Lincoln County \#2-255 & $<.06$ & 18 & $<.04$ & 3.4 & .05 & 6.6 & 22 & $<.08$ & 11.8 \\
\hline Lincoln County \#2-590 & $<.06$ & 45 & $<.04$ & $<.8$ & .21 & 7.3 & $<8$ & $<.08$ & 16.3 \\
\hline Lincoln County \#2-760 & $<.06$ & 45 & $<.04$ & 1.5 & .12 & 3.4 & $<8$ & $<.08$ & 14.1 \\
\hline Lincoln County \#3-30 & $<.06$ & 44 & $<.04$ & 2.2 & .22 & 5.6 & $<8$ & $<.08$ & 15.6 \\
\hline Lincoln County \#3-110 & $<.06$ & 45 & $<.04$ & 3.7 & .11 & .4 & $<8$ & $<.08$ & 16.1 \\
\hline Lincoln County \#3-250 & $<.06$ & 53 & E.02 & 2.0 & .11 & 2.1 & $<8$ & $<.08$ & 16.7 \\
\hline Lincoln County \#3-390 & $<.06$ & 78 & $<.04$ & 1.9 & .12 & .9 & E5. & $<.08$ & 21.2 \\
\hline Lincoln County \#4-195 & $<.06$ & 14 & $<.04$ & 3.8 & .11 & E. 3 & $<6$ & $<.08$ & 15.1 \\
\hline Lincoln County \#4-359 & $<.06$ & 22 & $<.04$ & $<.8$ & .18 & 2.9 & $<6$ & $<.08$ & 11.3 \\
\hline Lincoln County \#4-510 & $<.06$ & 32 & $<.04$ & $<.8$ & .18 & 2.6 & 6. & $<.08$ & 13.2 \\
\hline Lincoln County \#4-695 & $<.06$ & 70 & $<.04$ & E.6 & .17 & .4 & $<6$ & $<.08$ & 21.2 \\
\hline McPherson County \#1-45 & $<.06$ & 10 & $<.04$ & 2.5 & .10 & 5.8 & $<8$ & $<.08$ & 6.9 \\
\hline McPherson County \#1-330 & $<.06$ & 31 & $<.04$ & $<.8$ & .20 & .4 & $<8$ & $<.08$ & 5.4 \\
\hline McPherson County \#1-550 & $<.06$ & 40 & $<.04$ & $<.8$ & .29 & .5 & $<8$ & $<.08$ & 11.9 \\
\hline McPherson County \#1-770 & $<.06$ & 34 & E.02 & $<.8$ & .15 & .6 & $<6$ & E.04 & 12.6 \\
\hline
\end{tabular}


Appendix 1. Water-quality data from sampled monitoring wells screened in the northern High Plains aquifer and from the Platte River near Brady,

Nebraska.-Continued

$\left[\mathrm{mg} / \mathrm{L}\right.$, milligrams per liter; $\mu \mathrm{S} / \mathrm{cm}$, microsiemens per centimeter at $25^{\circ} \mathrm{C} ;{ }^{\circ} \mathrm{C}$, degrees Celsius; $\mathrm{CaCO}_{3}$, calcium carbonate; <, less than; $\mathrm{N}$, nitrogen;

P, phosphorus; NTU, nephelometric turbidity units; $\mu \mathrm{g} / \mathrm{L}$, micrograms per liter; $\mathrm{pCi} / \mathrm{L}$, picocuries per liter; --, no data; E, estimated]

\begin{tabular}{|c|c|c|c|c|c|c|c|c|c|}
\hline $\begin{array}{c}\text { Well/ } \\
\text { site name }\end{array}$ & $\begin{array}{l}\text { Manganese } \\
(\mathrm{Mn}), \text { dis- } \\
\text { solved ( } \mu \mathrm{g} / \mathrm{L})\end{array}$ & $\begin{array}{l}\text { Molybdenum } \\
\text { (Mo), dis- } \\
\text { solved } \\
(\mu \mathrm{g} / \mathrm{L})\end{array}$ & $\begin{array}{l}\text { Nickel } \\
(\mathrm{Ni}), \\
\text { dissolved } \\
(\mu \mathrm{g} / \mathrm{L})\end{array}$ & $\begin{array}{c}\text { Radon } \\
\text { (Rn) } \\
\text { (pCi/L) }\end{array}$ & $\begin{array}{l}\text { Selenium } \\
(\text { Se), } \\
\text { dissolved } \\
(\mu \mathrm{g} / \mathrm{L})\end{array}$ & $\begin{array}{c}\text { Silver } \\
(\mathrm{Ag}), \\
\text { dissolved } \\
(\mu \mathrm{g} / \mathrm{L})\end{array}$ & $\begin{array}{l}\text { Strontium } \\
(\mathrm{Sr}), \\
\text { dissolved } \\
(\mu \mathrm{g} / \mathrm{L})\end{array}$ & $\begin{array}{c}\text { Thallium (TI), } \\
\text { dissolved } \\
(\mu \mathrm{g} / \mathrm{L})\end{array}$ & $\begin{array}{c}\text { Uranium (U), } \\
\text { dissolved } \\
(\mu \mathrm{g} / \mathrm{L})\end{array}$ \\
\hline Platte River near Brady, Nebr. & 10.6 & 4.5 & 1.2 & -- & 1.3 & $<0.20$ & 504 & $<0.04$ & 12.3 \\
\hline Imperial & -- & -- & -- & -- & -- & -- & -- & -- & -- \\
\hline Keith County \#1 & .3 & 3.6 & .4 & -- & 3.0 & $<.20$ & 370 & $<.04$ & 5.2 \\
\hline Lincoln County \#1-25 & 104. & 2.0 & .8 & 270. & 2.3 & $<.20$ & 341 & E.02 & 1.5 \\
\hline Lincoln County \#1-119 & 177. & 2.1 & .3 & 380. & 1.1 & $<.20$ & 357 & $<.04$ & 1.0 \\
\hline Lincoln County \#1-270 & 37.9 & 1.1 & .3 & 380. & 3.1 & $<.20$ & 371 & $<.04$ & 1.6 \\
\hline Lincoln County \#1-370 & 21.1 & 3.7 & .7 & 870. & 1.8 & $<.20$ & 456 & $<.04$ & 5.1 \\
\hline Lincoln County \#2-255 & $<.2$ & 1.3 & .9 & 230. & 1.1 & $<.20$ & 89.9 & $<.04$ & .1 \\
\hline Lincoln County \#2-590 & 30.2 & 4.0 & 1.3 & 770. & E.5 & $<.20$ & 350 & $<.04$ & 4.4 \\
\hline Lincoln County \#2-760 & .9 & 2.6 & .7 & 580. & E. 4 & $<.20$ & 278 & $<.04$ & 2.5 \\
\hline Lincoln County \#3-30 & $<.2$ & 1.4 & 1.0 & 280. & 2.0 & $<.20$ & 650 & $<.04$ & 15.4 \\
\hline Lincoln County \#3-110 & $<.2$ & 4.0 & 6 & 510. & 1.5 & $<.20$ & 474 & $<.04$ & 6.8 \\
\hline Lincoln County \#3-250 & $<.2$ & 3.6 & 6 & 470. & 1.7 & $<.20$ & 423 & $<.04$ & 5.0 \\
\hline Lincoln County \#3-390 & 1.7 & 3.9 & .5 & 880. & 1.6 & $<.20$ & 647 & $<.04$ & 8.8 \\
\hline Lincoln County \#4-195 & 1.0 & .7 & .3 & 220. & 6 & $<.20$ & 63.4 & $<.04$ & E.03 \\
\hline Lincoln County \#4-359 & 20.0 & 1.5 & .8 & 140. & E. 4 & $<.20$ & 122 & $<.04$ & .4 \\
\hline Lincoln County \#4-510 & 35.1 & 1.6 & .7 & 100. & $<.4$ & $<.20$ & 188 & $<.04$ & .8 \\
\hline Lincoln County \#4-695 & 16.9 & 4.2 & 6 & 460. & $<.4$ & $<.20$ & 408 & E.02 & 4.3 \\
\hline McPherson County \#1-45 & 0.2 & E. 3 & .8 & 180. & .5 & $<.20$ & 74.5 & $<.04$ & .1 \\
\hline McPherson County \#1-330 & 43.8 & 1.7 & .6 & 280. & $<.5$ & $<.20$ & 148 & $<.04$ & .5 \\
\hline McPherson County \#1-550 & 95.4 & 1.9 & .8 & 190. & $<.5$ & $<.20$ & 293 & $<.04$ & 3.6 \\
\hline McPherson County \#1-770 & 20.7 & 5.3 & .4 & 190. & $<.4$ & $<.20$ & 249 & $<.04$ & 3.6 \\
\hline
\end{tabular}


Appendix 1. Water-quality data from sampled monitoring wells screened in the northern High Plains aquifer and from the Platte River near Brady, Nebraska.-Continued $\left[\mathrm{mg} / \mathrm{L}\right.$, milligrams per liter; $\mu \mathrm{S} / \mathrm{cm}$, microsiemens per centimeter at $25^{\circ} \mathrm{C} ;{ }^{\circ} \mathrm{C}$, degrees Celsius; $\mathrm{CaCO}_{3}$, calcium carbonate; <, less than; $\mathrm{N}$, nitrogen; $\mathrm{P}$, phosphorus; $\mathrm{NTU}$, nephelometric turbidity units; $\mu \mathrm{g} / \mathrm{L}$, micrograms per liter; $\mathrm{pCi} / \mathrm{L}$, picocuries per liter; --, no data; E, estimated]

\begin{tabular}{|c|c|c|c|c|c|c|c|c|c|c|}
\hline $\begin{array}{c}\text { Well/ } \\
\text { site name }\end{array}$ & $\begin{array}{l}\text { Vanadium } \\
\text { (V), dis- } \\
\text { solved } \\
(\mu \mathrm{g} / \mathrm{L})\end{array}$ & $\begin{array}{l}\text { Zinc } \\
(\mathrm{Zn}), \text { dis- } \\
\text { solved } \\
(\mu \mathrm{g} / \mathrm{L})\end{array}$ & $\begin{array}{l}\text { 2,6-Diethyl } \\
\text { aniline, } \\
\text { dissolved } \\
(\mu \mathrm{g} / \mathrm{L})\end{array}$ & $\begin{array}{l}\text { Acetochlor, } \\
\text { dissolved } \\
\text { ( } \mu \mathrm{g} / \mathrm{L})\end{array}$ & $\begin{array}{c}\text { Alachlor, } \\
\text { dissolved } \\
(\mu \mathrm{g} / \mathrm{L})\end{array}$ & $\begin{array}{l}\text { Alpha BHC, } \\
\text { dissolved } \\
(\mu \mathrm{g} / \mathrm{L})\end{array}$ & $\begin{array}{c}\text { Atrazine, } \\
\text { dissolved } \\
\text { ( } \mu \mathrm{g} / \mathrm{L})\end{array}$ & $\begin{array}{l}\text { Azinphos- } \\
\text { methyl, dis- } \\
\text { solved ( } \mu \mathrm{g} / \mathrm{L} \text { ) }\end{array}$ & $\begin{array}{c}\text { Benfluralin, } \\
\text { dissolved } \\
\text { ( } \mu \mathrm{g} / \mathrm{L})\end{array}$ & $\begin{array}{c}\text { Butylate, } \\
\text { dissolved } \\
\text { ( } \mu \mathrm{g} / \mathrm{L})\end{array}$ \\
\hline Platte River near Brady, Nebr. & 6.3 & 0.7 & -- & -- & -- & -- & -- & -- & -- & -- \\
\hline Imperial & -- & -- & $<0.006$ & $<0.006$ & $<0.004$ & $<0.005$ & $<0.007$ & $<0.05$ & $<0.01$ & $<0.002$ \\
\hline Keith County \#1 & 15.3 & .8 & -- & -- & -- & -- & -- & -- & -- & -- \\
\hline Lincoln County \#1-25 & 4.0 & $<1.0$ & $<.006$ & $<.006$ & $<.004$ & $<.005$ & $<.007$ & $<.05$ & $<.01$ & $<.002$ \\
\hline Lincoln County \#1-119 & 20.7 & $<1.0$ & $<.006$ & $<.006$ & $<.004$ & $<.005$ & $<.007$ & $<.05$ & $<.01$ & $<.002$ \\
\hline Lincoln County \#1-270 & 17.7 & $<1.0$ & $<.006$ & $<.006$ & $<.004$ & $<.005$ & $<.007$ & $<.05$ & $<.01$ & $<.002$ \\
\hline Lincoln County \#1-370 & 15.3 & $<1.0$ & $<.006$ & $<.006$ & $<.004$ & $<.005$ & $<.007$ & $<.05$ & $<.01$ & $<.002$ \\
\hline Lincoln County \#2-255 & 15.8 & $<1.0$ & $<.006$ & $<.006$ & $<.004$ & $<.005$ & $<.007$ & $<.05$ & $<.01$ & $<.002$ \\
\hline Lincoln County \#2-590 & 9.5 & $<1.6$ & $<.006$ & $<.006$ & $<.004$ & $<.005$ & $<.007$ & $<.05$ & $<.01$ & $<.002$ \\
\hline Lincoln County \#2-760 & 14.5 & $<1.0$ & $<.006$ & $<.006$ & $<.004$ & $<.005$ & $<.007$ & $<.05$ & $<.01$ & $<.002$ \\
\hline Lincoln County \#3-30 & 11.2 & $<1.0$ & $<.006$ & $<.006$ & $<.004$ & $<.005$ & $<.007$ & $<.05$ & $<.01$ & $<.002$ \\
\hline Lincoln County \#3-110 & 14.2 & $<1.0$ & $<.006$ & $<.006$ & $<.004$ & $<.005$ & $<.007$ & $<.05$ & $<.01$ & $<.002$ \\
\hline Lincoln County \#3-250 & 15.0 & $<1.0$ & $<.006$ & $<.006$ & $<.004$ & $<.005$ & $<.007$ & $<.05$ & $<.01$ & $<.002$ \\
\hline Lincoln County \#3-390 & 10.6 & $<1.0$ & $<.006$ & $<.006$ & $<.004$ & $<.005$ & $<.007$ & $<.05$ & $<.01$ & $<.002$ \\
\hline Lincoln County \#4-195 & 8.3 & $<.6$ & $<.006$ & $<.006$ & $<.004$ & $<.005$ & $<.007$ & $<.05$ & $<.01$ & $<.002$ \\
\hline Lincoln County \#4-359 & 12.9 & 6 & $<.006$ & $<.006$ & $<.004$ & $<.005$ & $<.007$ & $<.05$ & $<.01$ & $<.002$ \\
\hline Lincoln County \#4-510 & 13.4 & $<.6$ & $<.006$ & $<.006$ & $<.004$ & $<.005$ & $<.007$ & $<.05$ & $<.01$ & $<.002$ \\
\hline Lincoln County \#4-695 & 8.8 & E.4 & $<.006$ & $<.006$ & $<.004$ & $<.005$ & $<.007$ & $<.05$ & $<.01$ & $<.002$ \\
\hline McPherson County \#1-45 & 10.7 & $<1.0$ & $<.006$ & $<.006$ & $<.004$ & $<.005$ & $<.007$ & $<.05$ & $<.01$ & $<.002$ \\
\hline McPherson County \#1-330 & 8.7 & $<1.0$ & $<.006$ & $<.006$ & $<.004$ & $<.005$ & $<.007$ & $<.05$ & $<.01$ & $<.002$ \\
\hline McPherson County \#1-550 & 14.0 & $<1.0$ & $<.006$ & $<.006$ & $<.004$ & $<.005$ & $<.007$ & $<.05$ & $<.01$ & $<.002$ \\
\hline McPherson County \#1-770 & 9.7 & 9.5 & $<.006$ & $<.006$ & $<.005$ & $<.005$ & $<.007$ & $<.05$ & $<.01$ & $<.004$ \\
\hline
\end{tabular}


Appendix 1. Water-quality data from sampled monitoring wells screened in the northern High Plains aquifer and from the Platte River near Brady, Nebraska.-

\section{Continued}

$\left[\mathrm{mg} / \mathrm{L}\right.$, milligrams per liter; $\mu \mathrm{S} / \mathrm{cm}$, microsiemens per centimeter at $25^{\circ} \mathrm{C} ;{ }^{\circ} \mathrm{C}$, degrees Celsius; $\mathrm{CaCO}_{3}$, calcium carbonate; <, less than; $\mathrm{N}$, nitrogen; $\mathrm{P}$, phosphorus; $\mathrm{NTU}$, nephelometric turbidity units; $\mu \mathrm{g} / \mathrm{L}$, micrograms per liter; $\mathrm{pCi} / \mathrm{L}$, picocuries per liter; --, no data; E, estimated]

\begin{tabular}{|c|c|c|c|c|c|c|c|c|c|}
\hline $\begin{array}{c}\text { Well/ } \\
\text { site name }\end{array}$ & $\begin{array}{l}\text { Carbaryl, } \\
\text { dissolved } \\
\text { ( } \mu \mathrm{g} / \mathrm{L})\end{array}$ & $\begin{array}{c}\text { Carbofuran, } \\
\text { dissolved } \\
\text { ( } \mu \mathrm{g} / \mathrm{L})\end{array}$ & $\begin{array}{c}\text { Chlorpyrifos, } \\
\text { dissolved } \\
\text { ( } \mu \mathrm{g} / \mathrm{L})\end{array}$ & $\begin{array}{c}\text { Cyanazine, } \\
\text { dissolved } \\
(\mu \mathrm{g} / \mathrm{L})\end{array}$ & $\begin{array}{l}\text { DCPA, } \\
\text { dis- } \\
\text { solved } \\
(\mu \mathrm{g} / \mathrm{L})\end{array}$ & $\begin{array}{l}\text { Deethyl- } \\
\text { atrazine, } \\
\text { dissolved } \\
(\mu \mathrm{g} / \mathrm{L})\end{array}$ & $\begin{array}{l}\text { Diazinon, } \\
\text { dissolved } \\
\text { ( } \mu \mathrm{g} / \mathrm{L})\end{array}$ & $\begin{array}{l}\text { Dieldrin, } \\
\text { dissolved } \\
\text { ( } \mu \mathrm{g} / \mathrm{L})\end{array}$ & $\begin{array}{c}\text { Disulfoton, } \\
\text { dissolved } \\
(\mu \mathrm{g} / \mathrm{L})\end{array}$ \\
\hline Platte River near Brady, Nebr. & -- & -- & -- & -- & -- & -- & -- & -- & -- \\
\hline Imperial & $<0.041$ & $<0.02$ & $<0.005$ & $<0.018$ & $<0.003$ & $<0.006$ & $<0.005$ & $<0.005$ & $<0.05$ \\
\hline Keith County \#1 & -- & -- & -- & -- & -- & -- & -- & -- & -- \\
\hline Lincoln County \#1-25 & $<.041$ & $<.02$ & $<.005$ & $<.018$ & $<.003$ & $<.006$ & $<.005$ & $<.005$ & $<.02$ \\
\hline Lincoln County \#1-119 & $<.041$ & $<.02$ & $<.005$ & $<.018$ & $<.003$ & $<.006$ & $<.005$ & $<.005$ & $<.02$ \\
\hline Lincoln County \#1-270 & $<.041$ & $<.02$ & $<.005$ & $<.018$ & $<.003$ & $<.006$ & $<.005$ & $<.005$ & $<.02$ \\
\hline Lincoln County \#1-370 & $<.041$ & $<.02$ & $<.005$ & $<.018$ & $<.003$ & $<.006$ & $<.005$ & $<.005$ & $<.02$ \\
\hline Lincoln County \#2-255 & $<.041$ & $<.02$ & $<.005$ & $<.018$ & $<.003$ & $<.006$ & $<.005$ & $<.005$ & $<.02$ \\
\hline Lincoln County \#2-590 & $<.041$ & $<.02$ & $<.005$ & $<.018$ & $<.003$ & $<.006$ & $<.005$ & $<.005$ & $<.02$ \\
\hline Lincoln County \#2-760 & $<.041$ & $<.02$ & $<.005$ & $<.018$ & $<.003$ & $<.006$ & $<.005$ & $<.005$ & $<.02$ \\
\hline Lincoln County \#3-30 & $<.041$ & $<.02$ & $<.005$ & $<.018$ & $<.003$ & E.006 & $<.005$ & $<.005$ & $<.02$ \\
\hline Lincoln County \#3-110 & $<.041$ & $<.02$ & $<.005$ & $<.018$ & $<.003$ & $<.006$ & $<.005$ & $<.005$ & $<.02$ \\
\hline Lincoln County \#3-250 & $<.041$ & $<.02$ & $<.005$ & $<.018$ & $<.003$ & $<.006$ & $<.005$ & $<.005$ & $<.02$ \\
\hline Lincoln County \#3-390 & $<.041$ & $<.02$ & $<.005$ & $<.018$ & $<.003$ & $<.006$ & $<.005$ & $<.005$ & $<.02$ \\
\hline Lincoln County \#4-195 & $<.041$ & $<.02$ & $<.005$ & $<.018$ & $<.003$ & $<.006$ & $<.005$ & $<.005$ & $<.02$ \\
\hline Lincoln County \#4-359 & $<.041$ & $<.02$ & $<.005$ & $<.018$ & $<.003$ & $<.006$ & $<.005$ & $<.005$ & $<.02$ \\
\hline Lincoln County \#4-510 & $<.041$ & $<.02$ & $<.005$ & $<.018$ & $<.003$ & $<.006$ & $<.005$ & $<.005$ & $<.02$ \\
\hline Lincoln County \#4-695 & $<.041$ & $<.02$ & $<.005$ & $<.018$ & $<.003$ & $<.006$ & $<.005$ & $<.005$ & $<.02$ \\
\hline McPherson County \#1-45 & $<.041$ & $<.02$ & $<.005$ & $<.018$ & $<.003$ & $<.006$ & $<.005$ & $<.005$ & $<.02$ \\
\hline McPherson County \#1-330 & $<.041$ & $<.02$ & $<.005$ & $<.018$ & $<.003$ & $<.006$ & $<.005$ & $<.005$ & $<.02$ \\
\hline McPherson County \#1-550 & $<.041$ & $<.02$ & $<.005$ & $<.018$ & $<.003$ & $<.006$ & $<.005$ & $<.005$ & $<.02$ \\
\hline McPherson County \#1-770 & $<.041$ & $<.02$ & $<.005$ & $<.018$ & $<.003$ & $<.006$ & $<.005$ & $<.009$ & $<.02$ \\
\hline
\end{tabular}


Appendix 1. Water-quality data from sampled monitoring wells screened in the northern High Plains aquifer and from the Platte River near Brady, Nebraska.-Continued

$\left[\mathrm{mg} / \mathrm{L}\right.$, milligrams per liter; $\mu \mathrm{S} / \mathrm{cm}$, microsiemens per centimeter at $25^{\circ} \mathrm{C} ;{ }^{\circ} \mathrm{C}$, degrees Celsius; $\mathrm{CaCO}_{3}$, calcium carbonate; <, less than; N, nitrogen; P, phosphorus; NTU, nephelometric turbidity units; $\mu \mathrm{g} / \mathrm{L}$, micrograms per liter; $\mathrm{pCi} / \mathrm{L}$, picocuries per liter; --, no data; E, estimated]

\begin{tabular}{|c|c|c|c|c|c|c|c|c|}
\hline $\begin{array}{c}\text { Well/ } \\
\text { site name }\end{array}$ & $\begin{array}{c}\text { EPTC, } \\
\text { dissolved } \\
(\mu \mathrm{g} / \mathrm{L})\end{array}$ & $\begin{array}{c}\text { Ethalfluralin, } \\
\text { dissolved } \\
\text { ( } \mathrm{gg} / \mathrm{L})\end{array}$ & $\begin{array}{c}\text { Ethoprophos, } \\
\text { dissolved } \\
\text { ( } \mu \mathrm{g} / \mathrm{L})\end{array}$ & $\begin{array}{c}\text { Fipronil, } \\
\text { dissolved } \\
\text { ( } \mu \mathrm{g} / \mathrm{L})\end{array}$ & $\begin{array}{l}\text { Fipronil } \\
\text { sulfide, dis- } \\
\text { solved } \\
(\mu \mathrm{g} / \mathrm{L})\end{array}$ & $\begin{array}{l}\text { Fipronil } \\
\text { sulfone, } \\
\text { dissolved } \\
(\mu \mathrm{g} / \mathrm{L})\end{array}$ & $\begin{array}{c}\text { Fonofox, } \\
\text { dissolved } \\
\text { ( } \mu \mathrm{g} / \mathrm{L})\end{array}$ & $\begin{array}{l}\text { Lindane, } \\
\text { dissolved } \\
(\mu \mathrm{g} / \mathrm{L})\end{array}$ \\
\hline Platte River near Brady, Nebr. & -- & -- & -- & -- & -- & -- & -- & -- \\
\hline Imperial & $<0.002$ & $<0.009$ & $<0.005$ & $<0.007$ & $<0.005$ & $<0.005$ & $<0.003$ & $<0.004$ \\
\hline Keith County \#1 & -- & -- & -- & -- & -- & -- & -- & -- \\
\hline Lincoln County \#1-25 & $<.002$ & $<.009$ & $<.005$ & $<.007$ & $<.005$ & $<.005$ & $<.003$ & $<.004$ \\
\hline Lincoln County \#1-119 & $<.002$ & $<.009$ & $<.005$ & $<.007$ & $<.005$ & $<.005$ & $<.003$ & $<.004$ \\
\hline Lincoln County \#1-270 & $<.002$ & $<.009$ & $<.005$ & $<.007$ & $<.005$ & $<.005$ & $<.003$ & $<.004$ \\
\hline Lincoln County \#1-370 & $<.002$ & $<.009$ & $<.005$ & $<.007$ & $<.005$ & $<.005$ & $<.003$ & $<.004$ \\
\hline Lincoln County \#2-255 & $<.002$ & $<.009$ & $<.005$ & $<.007$ & $<.005$ & $<.005$ & $<.003$ & $<.004$ \\
\hline Lincoln County \#2-590 & $<.002$ & $<.009$ & $<.005$ & $<.007$ & $<.005$ & $<.005$ & $<.003$ & $<.004$ \\
\hline Lincoln County \#2-760 & $<.002$ & $<.009$ & $<.005$ & $<.007$ & $<.005$ & $<.005$ & $<.003$ & $<.004$ \\
\hline Lincoln County \#3-30 & $<.002$ & $<.009$ & $<.005$ & $<.007$ & $<.005$ & $<.005$ & $<.003$ & $<.004$ \\
\hline Lincoln County \#3-110 & $<.002$ & $<.009$ & $<.005$ & $<.007$ & $<.005$ & $<.005$ & $<.003$ & $<.004$ \\
\hline Lincoln County \#3-250 & $<.002$ & $<.009$ & $<.005$ & $<.007$ & $<.005$ & $<.005$ & $<.003$ & $<.004$ \\
\hline Lincoln County \#3-390 & $<.002$ & $<.009$ & $<.005$ & $<.007$ & $<.005$ & $<.005$ & $<.003$ & $<.004$ \\
\hline Lincoln County \#4-195 & $<.002$ & $<.009$ & $<.005$ & $<.007$ & $<.005$ & $<.005$ & $<.003$ & $<.004$ \\
\hline Lincoln County \#4-359 & $<.002$ & $<.009$ & $<.005$ & $<.007$ & $<.005$ & $<.005$ & $<.003$ & $<.004$ \\
\hline Lincoln County \#4-510 & $<.002$ & $<.009$ & $<.005$ & $<.007$ & $<.005$ & $<.005$ & $<.003$ & $<.004$ \\
\hline Lincoln County \#4-695 & $<.002$ & $<.009$ & $<.005$ & $<.007$ & $<.005$ & $<.005$ & $<.003$ & $<.004$ \\
\hline McPherson County \#1-45 & $<.002$ & $<.009$ & $<.005$ & $<.007$ & $<.005$ & $<.005$ & $<.003$ & $<.004$ \\
\hline McPherson County \#1-330 & $<.002$ & $<.009$ & $<.005$ & $<.007$ & $<.005$ & $<.005$ & $<.003$ & $<.004$ \\
\hline McPherson County \#1-550 & $<.002$ & $<.009$ & $<.005$ & $<.007$ & $<.005$ & $<.005$ & $<.003$ & $<.004$ \\
\hline McPherson County \#1-770 & $<.004$ & $<.009$ & $<.005$ & $<.016$ & $<.013$ & $<.024$ & $<.003$ & $<.004$ \\
\hline
\end{tabular}


Appendix 1. Water-quality data from sampled monitoring wells screened in the northern High Plains aquifer and from the Platte River near

Brady, Nebraska._Continued

$\left[\mathrm{mg} / \mathrm{L}\right.$, milligrams per liter; $\mu \mathrm{S} / \mathrm{cm}$, microsiemens per centimeter at $25^{\circ} \mathrm{C} ;{ }^{\circ} \mathrm{C}$, degrees Celsius; $\mathrm{CaCO}_{3}$, calcium carbonate; <, less than; $\mathrm{N}$, nitrogen; $\mathrm{P}$, phosphorus;

NTU, nephelometric turbidity units; $\mu \mathrm{g} / \mathrm{L}$, micrograms per liter; $\mathrm{pCi} / \mathrm{L}$, picocuries per liter; --, no data; E, estimated]

\begin{tabular}{|c|c|c|c|c|c|c|c|c|}
\hline $\begin{array}{c}\text { Well/ } \\
\text { site name }\end{array}$ & $\begin{array}{l}\text { Linuron, } \\
\text { dissolved } \\
(\mu \mathrm{g} / \mathrm{L})\end{array}$ & $\begin{array}{l}\text { Malathion, } \\
\text { dissolved } \\
(\mu \mathrm{g} / \mathrm{L})\end{array}$ & $\begin{array}{l}\text { Metolachlor, } \\
\text { dissolved } \\
(\mu \mathrm{g} / \mathrm{L})\end{array}$ & $\begin{array}{l}\text { Metribuzin, } \\
\text { dissolved } \\
(\mu \mathrm{g} / \mathrm{L})\end{array}$ & $\begin{array}{l}\text { Molinate, } \\
\text { dissolved } \\
(\mu \mathrm{g} / \mathrm{L})\end{array}$ & $\begin{array}{c}\text { Napropamide, } \\
\text { dissolved } \\
(\mu \mathrm{g} / \mathrm{L})\end{array}$ & $\begin{array}{c}\text { p,p'-DDE, } \\
\text { dissolved } \\
(\mu \mathrm{g} / \mathrm{L})\end{array}$ & $\begin{array}{c}\text { Parathion, } \\
\text { dissolved } \\
(\mu \mathrm{g} / \mathrm{L})\end{array}$ \\
\hline Platte River near Brady, Nebr. & -- & -- & -- & -- & -- & -- & -- & -- \\
\hline Imperial & $<0.035$ & $<0.027$ & $<0.013$ & $<0.006$ & $<0.002$ & $<0.007$ & $<0.003$ & $<0.01$ \\
\hline Keith County \#1 & -- & -- & -- & -- & -- & -- & -- & -- \\
\hline Lincoln County \#1-25 & $<.035$ & $<.027$ & $<.013$ & $<.006$ & $<.002$ & $<.007$ & $<.003$ & $<.01$ \\
\hline Lincoln County \#1-119 & $<.035$ & $<.027$ & $<.013$ & $<.006$ & $<.002$ & $<.007$ & $<.003$ & $<.01$ \\
\hline Lincoln County \#1-270 & $<.035$ & $<.027$ & $<.013$ & $<.006$ & $<.002$ & $<.007$ & $<.003$ & $<.01$ \\
\hline Lincoln County \#1-370 & $<.035$ & $<.027$ & $<.013$ & $<.006$ & $<.002$ & $<.007$ & $<.003$ & $<.01$ \\
\hline Lincoln County \#2-255 & $<.035$ & $<.027$ & $<.013$ & $<.006$ & $<.002$ & $<.007$ & $<.003$ & $<.01$ \\
\hline Lincoln County \#2-590 & $<.035$ & $<.027$ & $<.013$ & $<.006$ & $<.002$ & $<.007$ & $<.003$ & $<.01$ \\
\hline Lincoln County \#2-760 & $<.035$ & $<.027$ & $<.013$ & $<.006$ & $<.002$ & $<.007$ & $<.003$ & $<.01$ \\
\hline Lincoln County \#3-30 & $<.035$ & $<.027$ & $<.013$ & $<.006$ & $<.002$ & $<.007$ & $<.003$ & $<.01$ \\
\hline Lincoln County \#3-110 & $<.035$ & $<.027$ & $<.013$ & $<.006$ & $<.002$ & $<.007$ & $<.003$ & $<.01$ \\
\hline Lincoln County \#3-250 & $<.035$ & $<.027$ & $<.013$ & $<.006$ & $<.002$ & $<.007$ & $<.003$ & $<.01$ \\
\hline Lincoln County \#3-390 & $<.035$ & $<.027$ & $<.013$ & $<.006$ & $<.002$ & $<.007$ & $<.003$ & $<.01$ \\
\hline Lincoln County \#4-195 & $<.035$ & $<.027$ & $<.013$ & $<.006$ & $<.002$ & $<.007$ & $<.003$ & $<.01$ \\
\hline Lincoln County \#4-359 & $<.035$ & $<.027$ & $<.013$ & $<.006$ & $<.002$ & $<.007$ & $<.003$ & $<.01$ \\
\hline Lincoln County \#4-510 & $<.035$ & $<.027$ & $<.013$ & $<.006$ & $<.002$ & $<.007$ & $<.003$ & $<.01$ \\
\hline Lincoln County \#4-695 & $<.035$ & $<.027$ & $<.013$ & $<.006$ & $<.002$ & $<.007$ & $<.003$ & $<.01$ \\
\hline McPherson County \#1-45 & $<.035$ & $<.027$ & $<.013$ & $<.006$ & $<.002$ & $<.007$ & $<.003$ & $<.01$ \\
\hline McPherson County \#1-330 & $<.035$ & $<.027$ & $<.013$ & $<.006$ & $<.002$ & $<.007$ & $<.003$ & $<.01$ \\
\hline McPherson County \#1-550 & $<.035$ & $<.027$ & $<.013$ & $<.006$ & $<.002$ & $<.007$ & $<.003$ & $<.01$ \\
\hline McPherson County \#1-770 & $<.035$ & $<.027$ & $<.006$ & $<.006$ & $<.003$ & $<.007$ & $<.003$ & $<.01$ \\
\hline
\end{tabular}


Appendix 1. Water-quality data from sampled monitoring wells screened in the northern High Plains aquifer and from the Platte River near Brady, Nebraska.Continued

$\left[\mathrm{mg} / \mathrm{L}\right.$, milligrams per liter; $\mu \mathrm{S} / \mathrm{cm}$, microsiemens per centimeter at $25^{\circ} \mathrm{C} ;{ }^{\circ} \mathrm{C}$, degrees Celsius; $\mathrm{CaCO}_{3}$, calcium carbonate; <, less than; $\mathrm{N}$, nitrogen;

$\mathrm{P}$, phosphorus; NTU, nephelometric turbidity units; $\mu \mathrm{g} / \mathrm{L}$, micrograms per liter; $\mathrm{pCi} / \mathrm{L}$, picocuries per liter; --, no data; E, estimated]

\begin{tabular}{|c|c|c|c|c|c|c|c|c|c|}
\hline $\begin{array}{c}\text { Well/ } \\
\text { site name }\end{array}$ & $\begin{array}{c}\text { Parathion- } \\
\text { methyl, } \\
\text { dissolved } \\
(\mu \mathrm{g} / \mathrm{L})\end{array}$ & $\begin{array}{c}\text { Pebulate, } \\
\text { dissolved } \\
\text { ( } \mu \mathrm{g} / \mathrm{L})\end{array}$ & $\begin{array}{l}\text { Pendi- } \\
\text { methalin, } \\
\text { dissolved } \\
(\mu g / L)\end{array}$ & $\begin{array}{l}\text { Permethrin, } \\
\text { dissolved } \\
\text { ( } \mu \mathrm{g} / \mathrm{L})\end{array}$ & $\begin{array}{l}\text { Phorate, } \\
\text { dissolved } \\
\text { ( } \mu \mathrm{g} / \mathrm{L})\end{array}$ & $\begin{array}{c}\text { Prometon, } \\
\text { dissolved } \\
\text { ( } \mu \mathrm{g} / \mathrm{L})\end{array}$ & $\begin{array}{c}\text { Pronamide, } \\
\text { dissolved } \\
(\mu \mathrm{g} / \mathrm{L})\end{array}$ & $\begin{array}{l}\text { Propachlor, } \\
\text { dissolved } \\
(\mu \mathrm{g} / \mathrm{L})\end{array}$ & $\begin{array}{c}\text { Propanil, } \\
\text { dissolved } \\
\text { ( } \mu \mathrm{g} / \mathrm{L})\end{array}$ \\
\hline Platte River near Brady, Nebr. & -- & -- & -- & -- & -- & -- & -- & -- & -- \\
\hline Imperial & $<0.006$ & $<0.004$ & $<0.022$ & $<0.006$ & $<0.011$ & $<0.01$ & $<0.004$ & $<0.01$ & $<0.011$ \\
\hline Keith County \#1 & -- & -- & -- & -- & -- & -- & -- & -- & -- \\
\hline Lincoln County \#1-25 & $<.006$ & $<.004$ & $<.022$ & $<.006$ & $<.011$ & $<.01$ & $<.004$ & $<.01$ & $<.011$ \\
\hline Lincoln County \#1-119 & $<.006$ & $<.004$ & $<.022$ & $<.006$ & $<.011$ & $<.01$ & $<.004$ & $<.01$ & $<.011$ \\
\hline Lincoln County \#1-270 & $<.006$ & $<.004$ & $<.022$ & $<.006$ & $<.011$ & $<.01$ & $<.004$ & $<.01$ & $<.011$ \\
\hline Lincoln County \#1-370 & $<.006$ & $<.004$ & $<.022$ & $<.006$ & $<.011$ & $<.01$ & $<.004$ & $<.01$ & $<.011$ \\
\hline Lincoln County \#2-255 & $<.006$ & $<.004$ & $<.022$ & $<.006$ & $<.011$ & $<.01$ & $<.004$ & $<.01$ & $<.011$ \\
\hline Lincoln County \#2-590 & $<.006$ & $<.004$ & $<.022$ & $<.006$ & $<.011$ & $<.01$ & $<.004$ & $<.01$ & $<.011$ \\
\hline Lincoln County \#2-760 & $<.006$ & $<.004$ & $<.022$ & $<.006$ & $<.011$ & $<.01$ & $<.004$ & $<.01$ & $<.011$ \\
\hline Lincoln County \#3-30 & $<.006$ & $<.004$ & $<.022$ & $<.006$ & $<.011$ & $<.01$ & $<.004$ & $<.01$ & $<.011$ \\
\hline Lincoln County \#3-110 & $<.006$ & $<.004$ & $<.022$ & $<.006$ & $<.011$ & $<.01$ & $<.004$ & $<.01$ & $<.011$ \\
\hline Lincoln County \#3-250 & $<.006$ & $<.004$ & $<.022$ & $<.006$ & $<.011$ & $<.01$ & $<.004$ & $<.01$ & $<.011$ \\
\hline Lincoln County \#3-390 & $<.006$ & $<.004$ & $<.022$ & $<.006$ & $<.011$ & $<.01$ & $<.004$ & $<.01$ & $<.011$ \\
\hline Lincoln County \#4-195 & $<.006$ & $<.004$ & $<.022$ & $<.006$ & $<.011$ & $<.01$ & $<.004$ & $<.01$ & $<.011$ \\
\hline Lincoln County \#4-359 & $<.006$ & $<.004$ & $<.022$ & $<.006$ & $<.011$ & $<.01$ & $<.004$ & $<.01$ & $<.011$ \\
\hline Lincoln County \#4-510 & $<.006$ & $<.004$ & $<.022$ & $<.006$ & $<.011$ & $<.01$ & $<.004$ & $<.01$ & $<.011$ \\
\hline Lincoln County \#4-695 & $<.006$ & $<.004$ & $<.022$ & $<.006$ & $<.011$ & $<.01$ & $<.004$ & $<.01$ & $<.011$ \\
\hline McPherson County \#1-45 & $<.006$ & $<.004$ & $<.022$ & $<.006$ & $<.011$ & $<.01$ & $<.004$ & $<.01$ & $<.011$ \\
\hline McPherson County \#1-330 & $<.006$ & $<.004$ & $<.022$ & $<.006$ & $<.011$ & $<.01$ & $<.004$ & $<.01$ & $<.011$ \\
\hline McPherson County \#1-550 & $<.006$ & $<.004$ & $<.022$ & $<.006$ & $<.011$ & $<.01$ & $<.004$ & $<.01$ & $<.011$ \\
\hline McPherson County \#1-770 & $<.015$ & $<.004$ & $<.022$ & $<.006$ & $<.011$ & $<.01$ & $<.004$ & $<.025$ & $<.011$ \\
\hline
\end{tabular}


Appendix 1. Water-quality data from sampled monitoring wells screened in the northern High Plains aquifer and from the Platte River near Brady, Nebraska.-Continued

$\left[\mathrm{mg} / \mathrm{L}\right.$, milligrams per liter; $\mu \mathrm{S} / \mathrm{cm}$, microsiemens per centimeter at $25^{\circ} \mathrm{C} ;{ }^{\circ} \mathrm{C}$, degrees Celsius; $\mathrm{CaCO}_{3}$, calcium carbonate; <, less than; $\mathrm{N}$, nitrogen; $\mathrm{P}$, phosphorus; $\mathrm{NTU}$, nephelometric turbidity units; $\mu \mathrm{g} / \mathrm{L}$, micrograms per liter; $\mathrm{pCi} / \mathrm{L}$, picocuries per liter; --, no data; $\mathrm{E}$, estimated]

\begin{tabular}{|c|c|c|c|c|c|c|c|c|}
\hline $\begin{array}{c}\text { Well/ } \\
\text { site name }\end{array}$ & $\begin{array}{l}\text { Propargite, } \\
\text { dissolved } \\
(\mu \mathrm{g} / \mathrm{L})\end{array}$ & $\begin{array}{c}\text { Simazine, } \\
\text { dissolved } \\
(\mu \mathrm{g} / \mathrm{L})\end{array}$ & $\begin{array}{l}\text { Tebuthiuron, } \\
\text { dissolved } \\
\text { ( } \mathrm{gg} / \mathrm{L})\end{array}$ & $\begin{array}{l}\text { Terbacil, } \\
\text { dissolved } \\
\text { ( } \mu \mathrm{g} / \mathrm{L})\end{array}$ & $\begin{array}{l}\text { Terbufos, } \\
\text { dissolved } \\
(\mu \mathrm{g} / \mathrm{L})\end{array}$ & $\begin{array}{l}\text { Thiobencarb, } \\
\text { dissolved } \\
\text { ( } \mu \mathrm{g} / \mathrm{L})\end{array}$ & $\begin{array}{c}\text { Tri-allate, } \\
\text { dissolved } \\
\text { ( } \mu \mathrm{g} / \mathrm{L})\end{array}$ & $\begin{array}{c}\text { Trifluralin, } \\
\text { dissolved } \\
(\mu \mathrm{g} / \mathrm{L})\end{array}$ \\
\hline Platte River near Brady, Nebr. & -- & -- & -- & -- & -- & -- & -- & -- \\
\hline Imperial & $<0.02$ & $<0.005$ & $<0.02$ & $<0.034$ & $<0.02$ & $<0.005$ & $<0.002$ & $<0.009$ \\
\hline Keith County \#1 & -- & -- & -- & -- & -- & -- & -- & -- \\
\hline Lincoln County \#1-25 & $<.02$ & $<.005$ & $<.02$ & $<.034$ & $<.02$ & $<.005$ & $<.002$ & $<.009$ \\
\hline Lincoln County \#1-119 & $<.02$ & $<.005$ & $<.02$ & $<.034$ & $<.02$ & $<.005$ & $<.002$ & $<.009$ \\
\hline Lincoln County \#1-270 & $<.02$ & $<.005$ & $<.02$ & $<.034$ & $<.02$ & $<.005$ & $<.002$ & $<.009$ \\
\hline Lincoln County \#1-370 & $<.02$ & $<.005$ & $<.02$ & $<.034$ & $<.02$ & $<.005$ & $<.002$ & $<.009$ \\
\hline Lincoln County \#2-255 & $<.02$ & $<.005$ & $<.02$ & $<.034$ & $<.02$ & $<.005$ & $<.002$ & $<.009$ \\
\hline Lincoln County \#2-590 & $<.02$ & $<.005$ & $<.02$ & $<.034$ & $<.02$ & $<.005$ & $<.002$ & $<.009$ \\
\hline Lincoln County \#3-30 & $<.02$ & $<.005$ & $<.02$ & $<.034$ & $<.02$ & $<.005$ & $<.002$ & $<.009$ \\
\hline Lincoln County \#3-110 & $<.02$ & $<.005$ & $<.02$ & $<.034$ & $<.02$ & $<.005$ & $<.002$ & $<.009$ \\
\hline Lincoln County \#3-250 & $<.02$ & $<.005$ & $<.02$ & $<.034$ & $<.02$ & $<.005$ & $<.002$ & $<.009$ \\
\hline Lincoln County \#3-390 & $<.02$ & $<.005$ & $<.02$ & $<.034$ & $<.02$ & $<.005$ & $<.002$ & $<.009$ \\
\hline Lincoln County \#4-195 & $<.02$ & $<.005$ & $<.02$ & $<.034$ & $<.02$ & $<.005$ & $<.002$ & $<.009$ \\
\hline Lincoln County \#4-359 & $<.02$ & $<.005$ & $<.02$ & $<.034$ & $<.02$ & $<.005$ & $<.002$ & $<.009$ \\
\hline Lincoln County \#4-510 & $<.02$ & $<.005$ & $<.02$ & $<.034$ & $<.02$ & $<.005$ & $<.002$ & $<.009$ \\
\hline Lincoln County \#4-695 & $<.02$ & $<.005$ & $<.02$ & $<.034$ & $<.02$ & $<.005$ & $<.002$ & $<.009$ \\
\hline McPherson County \#1-45 & $<.02$ & $<.005$ & $<.02$ & $<.034$ & $<.02$ & $<.005$ & $<.002$ & $<.009$ \\
\hline McPherson County \#1-330 & $<.02$ & $<.005$ & $<.02$ & $<.034$ & $<.02$ & $<.005$ & $<.002$ & $<.009$ \\
\hline McPherson County \#1-550 & $<.02$ & $<.005$ & $<.02$ & $<.034$ & $<.02$ & $<.005$ & $<.002$ & $<.009$ \\
\hline
\end{tabular}




\section{Appendix 2}

\section{Mass-Balance Model Results}


Appendix 2. Average mass transfers, mineral saturation indices, isotope balances, and adjusted radiocarbon ages for final waters.

[Mass-balance calculations were performed with NETPATH (Plummer and others, 1994). Lincoln Co. \#2-255, Lincoln Co. \#4-195, and McPherson Co. \#1-45 were used as initial waters in the mass-balance models for each of the final waters, except those from Lincoln Co. \#3. Keith Co. \#1 was used as the initial water for the final waters from Lincoln Co. \#3. The listed mass transfers, isotope values, and radiocarbon ages represent averages of all plausible models. Mass transfers are in millimoles per kilogram of water. Positive mass transfers indicate mineral dissolution. Negative numbers indicate mineral precipitation; SI, saturation index; Positive SI values indicate the water is supersaturated with respect to the indicated mineral phase; Negative SI values indicate the water is undersaturated with respect to the indicated mineral phase; --, no models found; \pm , plus or minus one standard deviation]

\begin{tabular}{|c|c|c|c|c|c|c|c|c|c|}
\hline $\begin{array}{l}\text { Final } \\
\text { water }\end{array}$ & Calcite & $\begin{array}{l}\text { Lignite } \\
\left(\mathrm{CH}_{2} \mathrm{O}\right)\end{array}$ & $\begin{array}{l}\text { Calcium- } \\
\text { sodium } \\
\text { exchange }\end{array}$ & $\begin{array}{c}\text { Sodium } \\
\text { plagio } \\
\text { clase }\end{array}$ & Kaolinite & $\begin{array}{l}\text { Silica, } \\
\left(\mathrm{SiO}_{2}\right)\end{array}$ & Pyrite & Goethite & $\begin{array}{c}\text { Carbon } \\
\text { dioxide } \\
\left(\mathrm{CO}_{2}\right. \\
\text { gas })\end{array}$ \\
\hline Lincoln County \#1-119 & 0.298 & 0.487 & -0.033 & 0.093 & -0.064 & -0.212 & 0.014 & -0.014 & -0.008 \\
\hline Lincoln County \#1-270 & .168 & .341 & -.048 & .070 & -.048 & -.243 & .021 & -.021 & .001 \\
\hline Lincoln County \#1-370 & .117 & .234 & .090 & .103 & -.077 & -.286 & .033 & -.033 & .000 \\
\hline Lincoln County \#2-590 & .209 & .266 & .038 & .086 & -.060 & -.432 & .025 & -.025 & -.008 \\
\hline Lincoln County \#2-760 & .162 & .264 & .015 & .174 & -.120 & -.470 & .023 & -.023 & .000 \\
\hline Lincoln County \#3-110 & -.165 & .019 & .032 & .000 & .000 & -.096 & .011 & -.011 & .000 \\
\hline Lincoln County \#3-250 & -1.22 & .057 & -.198 & 1.06 & -.732 & -1.57 & .012 & -.012 & .000 \\
\hline Lincoln County \#3-390 & -1.77 & .000 & -.396 & 1.59 & -1.10 & -2.49 & .051 & -.051 & .000 \\
\hline Lincoln County \#4-359 & .231 & .393 & -.026 & .137 & -.094 & -.069 & .003 & -.003 & .002 \\
\hline Lincoln County \#4-695 & .309 & .347 & .210 & .082 & -.057 & -.234 & .035 & -.035 & -.002 \\
\hline McPherson County \#1-330 & -- & -- & -- & -- & -- & -- & -- & -- & -- \\
\hline McPherson County \#1-550 & -- & -- & -- & -- & -- & -- & -- & -- & -- \\
\hline
\end{tabular}


Appendix 2. Average mass transfers, mineral saturation indices, isotope balances, and adjusted radiocarbon ages for final waters.Continued

[Mass-balance calculations were performed with NETPATH (Plummer and others, 1994). Lincoln Co. \#2-255, Lincoln Co. \#4-195, and McPherson Co. \#1-45 were used as initial waters in the mass-balance models for each of the final waters, except those from Lincoln Co. \#3. Keith Co. \#1 was used as the initial water for the final waters from Lincoln Co. \#3. The listed mass transfers, isotope values, and radiocarbon ages represent averages of all plausible models. Mass transfers are in millimoles per kilogram of water. Positive mass transfers indicate mineral dissolution. Negative numbers indicate mineral precipitation; SI, saturation index; Positive SI values indicate the water is supersaturated with respect to the indicated mineral phase; Negative SI values indicate the water is undersaturated with respect to the indicated mineral phase; --, no models found; \pm , plus or minus one standard deviation]

\begin{tabular}{|c|c|c|c|c|c|c|c|}
\hline $\begin{array}{l}\text { Final } \\
\text { water }\end{array}$ & $\begin{array}{c}\text { Nitrogen } \\
\left(\mathrm{N}_{2}\right) \\
\text { gas }\end{array}$ & $\begin{array}{c}\text { Evaporation } \\
\text { factor }\end{array}$ & Calcite SI & Albite SI & $\begin{array}{c}\text { Anorthite } \\
\text { SI }\end{array}$ & Kaolinite SI & Chalcedony SI \\
\hline Lincoln County \#1-119 & -0.036 & 1.36 & 0.010 & -1.213 & -3.988 & 2.856 & 0.690 \\
\hline Lincoln County \#1-270 & .000 & 1.58 & .021 & -1.326 & -4.049 & 2.641 & .685 \\
\hline Lincoln County \#1-370 & .000 & 2.17 & .023 & -.078 & -2.840 & 3.909 & .715 \\
\hline Lincoln County \#2-590 & .000 & 2.10 & .071 & -.264 & -2.572 & 4.180 & .685 \\
\hline Lincoln County \#2-760 & .000 & 1.66 & .035 & -1.192 & -4.196 & 2.369 & .642 \\
\hline Lincoln County \#3-110 & .000 & 1.08 & .057 & -.938 & -3.973 & 3.154 & .682 \\
\hline Lincoln County \#3-250 & .000 & 1.50 & -.030 & -.588 & -3.973 & 3.137 & .720 \\
\hline Lincoln County \#3-390 & .000 & 2.17 & .012 & -.636 & -4.107 & 2.979 & .685 \\
\hline Lincoln County \#4-359 & -.001 & 1.02 & -.192 & -1.244 & -3.855 & 2.810 & .652 \\
\hline Lincoln County \#4-510 & -.007 & 1.27 & -.113 & -1.400 & -4.172 & 2.492 & .676 \\
\hline Lincoln County \#4-695 & -.030 & 1.85 & -.056 & -.423 & -3.640 & 3.217 & .741 \\
\hline McPherson County \#1-330 & -- & -- & -- & -- & -- & -- & -- \\
\hline McPherson County \#1-550 & -- & -- & -- & -- & -- & -- & -- \\
\hline
\end{tabular}


Appendix 2. Average mass transfers, mineral saturation indices, isotope balances, and adjusted radiocarbon ages for final waters.-Continued

[Mass-balance calculations were performed with NETPATH (Plummer and others, 1994). Lincoln Co. \#2-255, Lincoln Co. \#4-195, and McPherson Co. \#1-45 were used as initial waters in the mass-balance models for each of the final waters, except those from Lincoln Co. \#3. Keith Co. \#1 was used as the initial water for the final waters from Lincoln Co. \#3. The listed mass transfers, isotope values, and radiocarbon ages represent averages of all plausible models. Mass transfers are in millimoles per kilogram of water. Positive mass transfers indicate mineral dissolution. Negative numbers indicate mineral precipitation; SI, saturation index; Positive SI values indicate the water is supersaturated with respect to the indicated mineral phase; Negative SI values indicate the water is undersaturated with respect to the indicated mineral phase; --, no models found; \pm , plus or minus one standard deviation]

\begin{tabular}{|c|c|c|c|c|c|}
\hline $\begin{array}{l}\text { Final } \\
\text { water }\end{array}$ & $\begin{array}{c}\delta^{13} \mathbf{C} \\
\text { [calcite] }\end{array}$ & $\begin{array}{c}\delta^{13} \mathrm{C} \text { [organic } \\
\text { carbon] }\end{array}$ & $\begin{array}{l}\delta^{13} C[D I C] \\
\text { measured }\end{array}$ & $\begin{array}{l}\delta^{13} \mathrm{C}[\mathrm{DIC}] \\
\text { modeled }\end{array}$ & $\begin{array}{c}\text { Adjusted } \\
\text { radiocarbon age } \\
\left({ }^{14} \mathrm{C} \text { years }\right)\end{array}$ \\
\hline Lincoln County \#1-119 & -4 & -20 & -9.6 & -9.9 & $1,800 \pm 900$ \\
\hline Lincoln County \#1-270 & -4 & -20 & -8.7 & -9.7 & $2,500 \pm 900$ \\
\hline Lincoln County \#1-370 & -4 & -20 & -9.7 & -9.6 & $12,600 \pm 900$ \\
\hline Lincoln County \#2-590 & -6 & -25 & -11.0 & -9.6 & $11,700 \pm 800$ \\
\hline Lincoln County \#2-760 & -7 to -2 & -25 & -9.6 & -9.3 & $7,500 \pm 900$ \\
\hline Lincoln County \#3-110 & -- & -25 & -7.4 & -8.1 & $7,400 \pm 400$ \\
\hline Lincoln County \#3-250 & -- & -25 & -14.0 & -9.2 & $7,400 \pm 400$ \\
\hline Lincoln County \#3-390 & -- & -25 & -9.7 & -8.6 & $15,700 \pm 500$ \\
\hline Lincoln County \#4-359 & -4 to -2 & -20 & -7.1 & -9.6 & $2,100 \pm 300$ \\
\hline Lincoln County \#4-510 & -4 to -2 & -20 & -8.0 & -9.5 & $5,800 \pm 700$ \\
\hline Lincoln County \#4-695 & -4 to -2 & -20 & -10.0 & -9.3 & $12,600 \pm 800$ \\
\hline McPherson County \#1-330 & -- & -- & -- & -- & -- \\
\hline McPherson County \#1-550 & -- & -- & -- & -- & -- \\
\hline
\end{tabular}




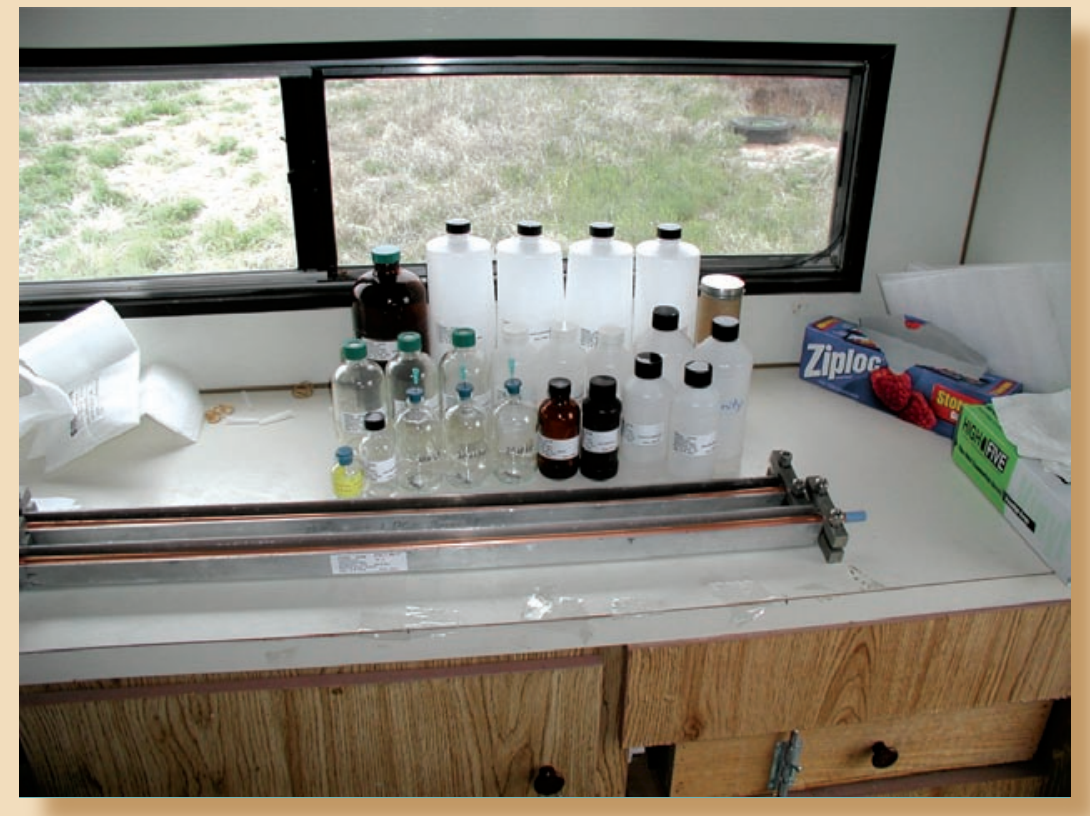

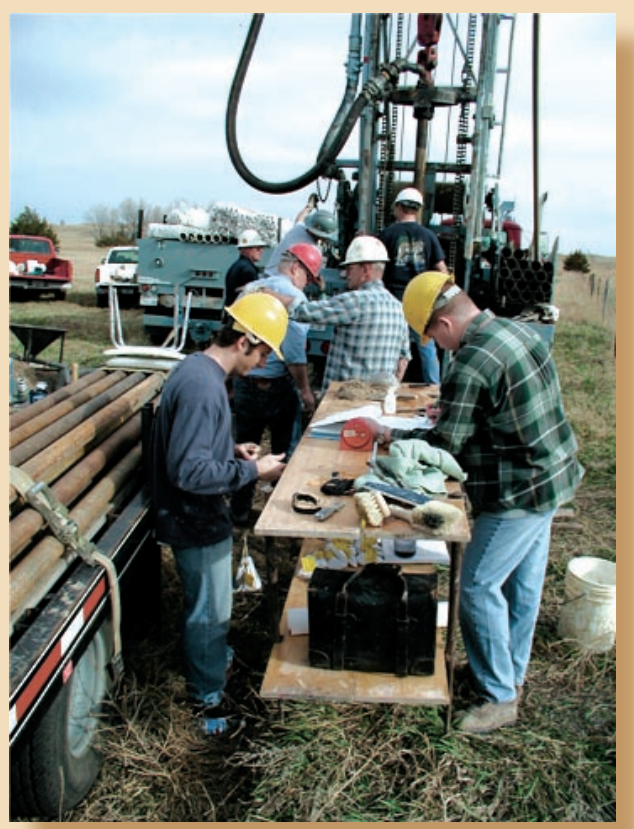

8

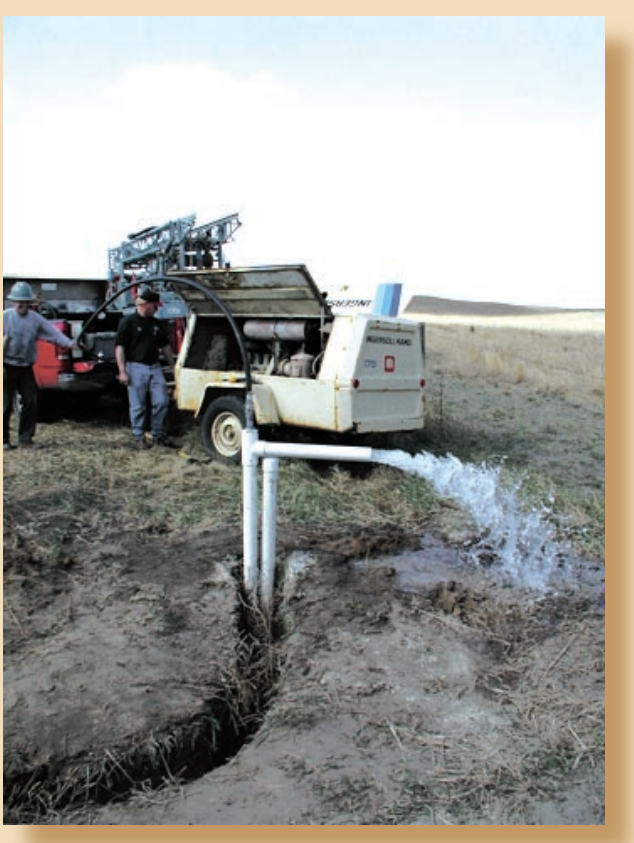

ISBN 141131773-4

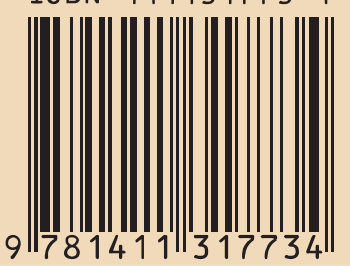

